\title{
Factors influencing basal area growth of yellow-poplar ( Liriodendron tulipifera L.) in central West Virginia
}

Christopher T. Crum

West Virginia University

Follow this and additional works at: https://researchrepository.wvu.edu/etd

\section{Recommended Citation}

Crum, Christopher T., "Factors influencing basal area growth of yellow-poplar ( Liriodendron tulipifera L.) in central West Virginia" (2004). Graduate Theses, Dissertations, and Problem Reports. 1533.

https://researchrepository.wvu.edu/etd/1533

This Thesis is protected by copyright and/or related rights. It has been brought to you by the The Research Repository @ WVU with permission from the rights-holder(s). You are free to use this Thesis in any way that is permitted by the copyright and related rights legislation that applies to your use. For other uses you must obtain permission from the rights-holder(s) directly, unless additional rights are indicated by a Creative Commons license in the record and/ or on the work itself. This Thesis has been accepted for inclusion in WVU Graduate Theses, Dissertations, and Problem Reports collection by an authorized administrator of The Research Repository @ WVU. For more information, please contact researchrepository@mail.wvu.edu. 


\title{
Factors Influencing Basal Area Growth of Yellow-Poplar (Liriodendron tulipifera L.) in Central West Virginia
}

\author{
Christopher T. Crum
}

Thesis submitted to the Davis College of Agriculture, Forestry, and Consumer Sciences at West Virginia University in partial fulfillment of the requirements for the degree of

\author{
Master of Science \\ in \\ Forestry
}

Ray R. Hicks Jr., Ph.D., Chair

John R. Brooks, Ph.D.

William N. Grafton

Davis College of Agriculture, Forestry, and Consumer Sciences

Division of Forestry

\author{
Morgantown, West Virginia \\ 2004
}

Keywords: Basal Area Growth, Diameter, Yellow-Poplar, Liriodendron tulipifera L., Topography, Tree Characteristics, GIS

Copyright 2004 Christopher T. Crum 


\begin{abstract}
Factors Influencing Basal Area Growth of Yellow-Poplar (Liriodendron tulipifera L.) in Central West Virginia
\end{abstract}

\author{
Christopher T. Crum
}

This paper uses data from continuous forest inventory (CFI) plots to evaluate basal area growth of yellow-poplar (Liriodendron tulipifera $\mathrm{L}$.) as related to four topographic factors (aspect, slope position, steepness, and landform), two competition variables (basal area per acre and trees per acre) and four tree characteristics (age, diameter, total height, and crown diameter). These variables were plotted against basal area growth per year using simple linear regression on 69 yellow-poplar trees. The four tree characteristics all had a highly significant $(\mathrm{p}<.01)$ relationship with basal area growth. While the other variables did not exhibit a significant relationship, the two competition variables did have a significant $(\mathrm{p}<.05)$ relationship with each other. 


\section{ACKNOWLEDGEMENTS}

First, I will have to thank God for helping me through these past three years. Then, I would like to thank Ed Grafton "Doc" for being such a good friend. I would like to thank Dr. Ray R. Hicks Jr., Dr. John R. Brooks, and Mr. Bill Grafton for serving on my advisory committee, and I would also like to thank my wife Faith for being by my side. 


\section{TABLE OF CONTENTS}

I. Abstact................................................. ii

II. Acknowledgements.................................... iii

III. List of Tables..................................... vi

IV. List of Figures................................... vii

V. Chapter 1: Introduction.................................. 1

Project Background.....................1

Objectives............................... 3

VI. Chapter 2: Literature Review........................... 5

Tree Characteristics...................... 5

Site Characteristics....................... 7

Basal Area Growth...................... 9

VII. Chapter 3: Methods.................................... 12

Data.................................. 12

Field Observations....................... 15

Data Analysis........................... 17

VIII. Chapter 4: Results................................... 22

Topographic Factors..................... 22

Competition Variables.................... 22

Tree Characteristics...................... 24

IX. Chapter 5: Discussion............................... 26

Topographic Factors...................... 26 
Competition Variables................... 27

Tree Characteristics........................ 28

X. Chapter 6: Conclusion / Comments...................... 32

Topographic Factors...................... 32

Competition Variables..................... 32

Tree Characteristics........................ 33

Other Objectives............................ 34

XI. References............................................ 35

XII. Appendix A: Data...................................... 40

XIII. Appendix B: GIS Maps............................. 53

XIV. Appendix C: Graphs................................. 55

XV. Appendix D: SAS Output............................. 66 


\section{LIST OF TABLES}

Table 3.1: Coordinates for each CFI center point in decimal degrees............. 17

Table 3.2: Variables and their abbreviations............................... 21

Table 4.1: $\mathrm{R}^{2}$ values of topographic factors and topographic variable results from SAS

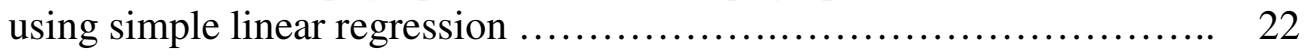

Table 4.2: $\mathrm{R}^{2}$ values of competition variables using simple linear regression.........23

Table 4.3: Competition variable results from SAS ......................... 23

Table 4.4: $\mathrm{R}^{2}$ values associated with the tree characteristics against basal area growth per year using simple linear regression....................... 24

Table 4.5: Linear regression parameters for tree characteristics................ 25

Table A.1: Topographic Factors..................................... 41

Table A.2: Initial Tree Measurements.................................. 43

Table A.3: Final Tree Measurements........................................46

Table A.4: Tree Characteristics....................................... 48

Table A.5: Competition Variables........................................ 50 


\section{LIST OF FIGURES}

Figure 1.1: A transverse section through an annual ring of yellow-poplar showing the vessels, trachieds and ray cells.............................................

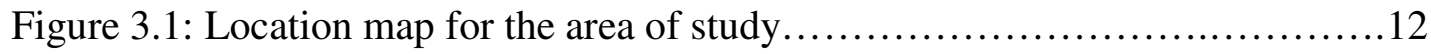

Figure 3.2: Location of the CFI plots................................... 14

Figure 3.3: The number of yellow-poplar sample trees by plot number........... 16

Figure 3.4: Values assigned to azimuths................................19

Figure A.1: Basal Area Growth per Year Plotted Against Topographic Factors..... 58

Figure A.2: Basal Area Growth per Year Plotted Against Basal Area per Acre and Trees per Acre .................................................... 58

Figure A.3: Change in Basal Area per Acre per Year Versus Change in Trees per Acre per Year..................................................... 59

Figure A.4: Basal Area Growth per Year Plotted Against Average Age ......... 59

Figure A.5: Basal Area Growth per Year Plotted Against Average Total Height ...60

Figure A.6: Basal Area Growth per Year Plotted Against Average DBH ..........60

Figure A.7: Basal Area Growth per Year Plotted Against Average Crown Diameter...................................................... 61

Figure A.8: Basal Area Growth per Year Plotted Against Change in Tree Characteristics per Year........................................................... 61

Figure A.9: Basal Area Growth per Year Plotted Against Initial Tree Characteristic Measurements................................................ 62

Figure A.10: Basal Area Growth per Year Plotted Against Final Tree Characteristic Measurements..................................................... 62

Figure A.11: Basal Area Growth per Year Plotted Against Residuals for Multiple Linear Regression Using the Averages of the Tree Characteristics................63

Figure A.12: Average DBH Plotted Against Residuals for Multiple Linear Regression Using the Averages of the Tree Characteristics... 
Figure A.13: Average Crown Diameter Plotted Against Residuals for Multiple Linear Regression Using the Averages of the Tree Characteristics..................64

Figure A.14: Average Age Plotted Against Residuals for Multiple Linear Regression Using the Averages of the Tree Characteristics........................... 64

Figure A.15: Average Total Height Plotted Against Residuals for Multiple Linear Regression Using the Averages of the Tree Characteristics.................. 65 


\section{CHAPTER 1: INTRODUCTION}

\section{Project Background}

Basal area growth is a function of the amount of xylem produced by the cambium layer. The quantity and size of xylem cells of a given species is directly related to the size of the crown and the amount of hormones and photosynthate produced by the foliage (Barnes et al., 1998). Photosynthate is first allocated to respiration, production of fine roots, seed production, primary growth (branch and root extension), and lastly to xylem growth and defense from insects and diseases (Oliver and Larson, 1996). Any factor that limits the production of photosynthate should, in turn, decrease the amount and/or size of the xylem cells and decrease basal area growth.

Yellow-poplar (Liriodendron tulipifera L.) is a fast growing, shade intolerant species. It grows in the eastern United States from central New York to Florida and west

to Michigan and Louisiana. Yellow-poplar can be found on deep, rich, moist soils along streams or around swampy areas; usually mixed with other broadleaf trees or eastern hemlock (Tsuga canadensis (L.) Carr.) (USDA, 1965). This species is most abundant and reaches its largest size in the valleys of lower Ohio and in the mountains of North Carolina, Tennessee, Georgia, Kentucky, Virginia, and West Virginia (Olson, 1969). Yellow-poplar is a species with excellent potential for forest management. Not only is this tree abundant and fast-growing but it has good form, straight trunks, and good natural pruning ability. There are a variety of markets for yellow-poplar wood which makes this tree a very valuable timber resource in West Virginia. 
Figure 1.1: A transverse section through an annual ring of yellow-poplar showing the vessels, trachieds and ray cells.

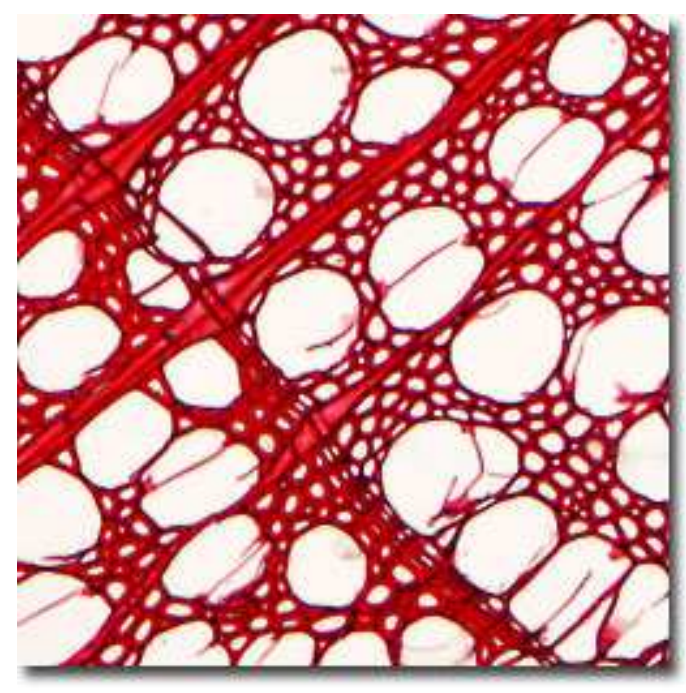

http://www.microscopy.fsu.edu/trees/pages/tulippoplar.html

Basal area growth may vary by rate and seasonal timing for different species. This can be seen when examining the xylem cells of a tree in the transverse section. Yellow-poplar is a diffuse-porous hardwood that has a fairly uniform distribution of vessels throughout the growth ring (Barnes et al., 1998). This indicates that yellowpoplar has a relatively consistent growth rate throughout the growing season. Sustained growth can also be seen in the shoots of yellow-poplar, which have continued growth late in the growing season on sites where moisture continues to be adequate. A study conducted in the lower Piedmont of North Carolina showed that yellow-poplar had a 160day height-growth period beginning in early April and ending about the middle of September. Extension growth was fairly constant, with no peak during the growing season (Olson, 1969). Because yellow-poplar has sustained growth it is considered more site-sensitive than most ashes (Fraxinus spp.), oaks (Quercus spp.), or hickories (Carya spp.) (Oliver and Larson, 1996). Several studies have found that yellow-poplar trees 
outgrow other species on good sites, but oaks will outgrow yellow-poplar trees on poor sites (Fekedulegn et al., 2002; Carmean and Hahn, 1983). In the central Appalachians, northeast aspects are typically better sites and southwest aspects are typically poorer.

\section{Objectives}

Basal area growth for this study was on an individual tree basis and was determined from two diameter outside bark measurements taken several years apart using the following formula:

$$
B A G Y=\left(0.005454 D B H_{t_{2}}{ }^{2}-0.005454 D B H_{t_{1}}{ }^{2}\right) / \operatorname{years}_{\left(t_{1}-t_{2}\right)}
$$

Where:

BAGY = basal area growth per year

$\mathrm{DBH}=$ the diameter at breast height (four and a half feet from the ground on the upslope side of the tree)

$\mathrm{t}_{1}=$ the time of the first DBH measurements

$\mathrm{t}_{2}=$ the time of the second DBH measurements

years $_{\left(t_{1}-t_{2}\right)}=$ the interval between the two measurements

The basal area growth per year (BAGY) was then examined in relation to several tree characteristics and site characteristics.

The specific objectives of this study were:

1. The main objective of this paper was to see how certain tree characteristics, topographic variables, and competition variables relate to basal area growth. The tree characteristics examined included crown diameter, $\mathrm{DBH}$, total height, and age. The competition variables included basal area per acre and trees per acre and the topographic variables were aspect, slope position, steepness, and landform. 
2. A secondary objective was to determine the utility of continuous forest inventory (CFI) data for calculating basal area growth. 


\section{CHAPTER 2: LITERATURE REVIEW}

\section{Tree Characteristics}

Foresters have made many comparisons between different tree characteristics. Some of these have been used to develop useful tools in forestry practice. For example, site index (a measure of site quality) is the average height of the dominant and codominant trees in the stand in relation to some index age. In West Virginia the base age for site index is normally 50 years. Not all trees follow the same height growth curve, even if they are the same species. Foresters understand that trees grow differently in different areas, but they also understand that an underlying relationship exists between age and total height.

Carmean and Hahn (1983) published a study comparing site indicies of five oak species and yellow-poplar. They used the site index of one species to predict the site index of another using linear regression. The equations accounted for from 40 to 89 percent of the variation in site index for each of the 13 species pairs.

A study by Phillips (1966) related the site index of yellow-poplar to soil and topography. He found that the depth to mottling, depth to tight subsoil, clay content of the subsoil, topographic position, and surface soil drainage were all related to site index. He derived an equation that explained approximately 67 percent of the observed variation in site index. Van Lear and Hosner (1967) were unable to find a relationship between site index of yellow-poplar and soil mapping units in southwest Virginia.

Several studies have investigated the relationship between diameter and age

(Gibbs, 1963; Kenefic and Nyland, 1999; O’Brien et al., 1995; Loewenstein et al., 2000; Leak, 1985). Kenefic and Nyland (1999) develop an equation which explained 81 
percent of the variation between age and diameter of sugar maple (Acer saccharum Marsh.) in an uneven-aged stand in New York. Loewenstein et al. (2000) used several equations to predict age from DBH in a managed uneven-aged oak forest. The resulting $\mathrm{R}^{2}$ values ranged from 0.404 for red oak (Quercus rubra $\mathrm{L}$.) to 0.619 for white oak ( $Q$. $a l b a \mathrm{~L}$.). It was stated that accurate prediction of tree age from diameter is impossible. Leak's (1985) study, conducted in an old-growth northern hardwoods and spruce-fir (Picea-Abies) stand, found that age and size are fairly well correlated. The $\mathrm{R}^{2}$ values ranged from 0.47 to 0.92 . Gibbs (1963) stated that for unmanaged mountain hardwoods in Parsons, West Virginia there was extreme variability in the tree age-DBH relationship. The tree ages were placed in groups according to their DBH class. Among the species used in this study, yellow-poplar showed the least variability in age within the DBH classes. O'Brien et al. (1995) looked at eight neotropical tree species in Panama. They checked relationships between diameter, height, crown, and age. The best correlations were with total height-diameter and crown-diameter relationships.

As mentioned earlier, crown size is related to tree growth and several studies have examined crown dimensions and how they relate to diameter or basal area growth (Bragg, 2001; Dean, 2004; Smith et al., 1992; Ottorini et al., 1996; Miller, 2000; Strub et al., 1975). Dean (2004) looked at three pine (Pinus spp.) species. He implied that basal area growth occurs in response to the mechanical stress on the tree's trunk. Smith et al. (1992) also studied growth of three pine species. These pines were open grown and showed high correlations $\left(\mathrm{R}^{2}=0.878\right.$ to $\left.\mathrm{R}^{2}=0.914\right)$ for the crown-basal area growth relationship. The other studies mentioned looked at other factors such as stand age, 
density (trees per unit area), average height of dominants and codominants, competition and branch arrangement.

\section{Site Characteristics}

Physiographic factors influence many other key ecosystem features, which make them a big part of forest management (Barnes et al., 1998). Physiographic factors include such things as aspect, slope position, and slope steepness. These are in turn related to the amount of solar energy and soil characteristics of the site. However, physiographic factors can be difficult to distinguish, and more research is needed before landscape features can be used in mathematical models to accurately classify ecosystems (Carmean, 1975).

One example of an influence of a physiographic factor is the effect of slope position on soil. Soil is usually shallower at upper slope positions because it is exposed to the action of wind, precipitation and gravity. Slope position also influences the amount of soil moisture and nutrient accumulation (Barnes et al., 1998). The lower the slope position the higher the soil moisture and biomass accumulation. Soil is usually shallower on steeper terrain because more erosion had occurred. Barnes et al. (1998) found that in dissected terrain, the greatest site index was on northeast aspects and the lowest was on south and west aspects. They also found that when both aspect and slope steepness are considered, a higher site index can be found with lower slope percentages and on the northeast aspects. Hicks and Frank (1984) suggest that aspect may directly or indirectly affect the properties of the upper soil horizons.

McNab (1993) conducted a study on topographic features and site index of yellow-poplar in North Carolina. One of the factors investigated was landform index. 
Landforms were divided into three categories: ridge, slope, and cove. He stated that site index of yellow-poplar was weakly correlated with most conventional soil-site variables and only landform index and terrain shape index were significantly correlated with site index at each location.

In another study, McNab (1987) compared age, aspect, and shape index to total height of yellow-poplar. The shape index was derived from two different slope types: side and head. He stated that age had about the same importance on both slope types, explaining about 75 percent of the total variation. Also, surface shape was of lesser importance than aspect, but caused a uniform response to estimated site index on both slope types.

A third study by McNab (1989) related the terrain shape index (which was estimated from percent slope) and lateral shape class (concave, linear, or convex) to total height of yellow-poplar in North Carolina. All sample plots were located on middle to lower slopes. The study showed that the terrain shape index was significantly related to lateral shape class for all three areas.

Munn and Vimmerstedt (1980) compared height growth of yellow-poplar to soil and topography in southern Ohio and found that 65 percent of the variability in height could be explained by soil chemical or physical characteristics and topographic features. Auten (1945) also did a study comparing site index for yellow-poplar to soil and topography. His study included cutover areas in southeastern Ohio, southern Indiana and Illinois, Kentucky, and Tennessee. Auten (1945) indicated that the most important factor was depth to tight subsoil. It was also mentioned that site index increased by about three feet for each inch the A horizon increased in depth, between one and eight inches of total 
thickness. Frank et al. (1984) used weighted stepwise regression to develop a model that explained 65 percent of the variation between biomass and soil-site factors in West Virginia.

Stage (1976) recommends combining the effect of slope and aspect when relating them to tree growth. Poage and Tappeiner (2002) examined the relationship between diameter and basal area growth of old-growth Douglas-fir (Pseudotsuga menziesii (Mirb.) Franco) trees in western Oregon. The site factors of province, site class, slope, aspect, and elevation explained less than 8 percent of the variation when slope and aspect were combined prior to the analysis. In a study of two Eucalyptus species in Israel by Brunori et al. (1995), the effect of slope position and aspect with tree growth were highly significant. There was no significant difference between the species studied.

\section{Basal Area Growth}

Monserud and Sterba (1996) conducted an extensive study on even and unevenaged forest stands in Austria. This study used remeasured trees growing on 5,416 plots. Each of the nine major species or species groups were fitted to their own model. Variables and resulting $\mathrm{R}^{2}$ values when used individually to predict basal area growth included: DBH and crown length (0.14 to 0.47), a competition variable (0.15), topographic factors (elevation, slope, aspect) (0.03), and other site factors such as vegetation type and growth district (up to 0.03 ). Total site factors only explained two to six percent of the variation in basal area growth. The total model explained 20 to 63 percent of the variation in basal area growth for the nine species.

Another interesting study was completed for maritime pine (Pinus pinaster Ait.) in Northwestern Spain by Schroder et al. (2002). They indicated that basal area growth is 
a function of initial size, historical vigor, competition, and site productivity. Their results showed basal area increased with increasing diameter, crown spread, soil depth and decreasing competition. The model explained more than 78 percent of the total growth variation as indicated by an adjusted $\mathrm{R}^{2}$ value.

The study that most closely resembles the present study is a thesis completed by Gibbs (1969). His study compared tree characteristics to basal area growth on five species [black cherry (Prunus serotina Ehrh.), red oak, sugar maple, and yellow-poplar]. Red oak was examined separately on two areas with site indicies of 60 and 80 . All other species were examined on areas with a site index of 80 . The variables computed for comparison are four-year basal area growth, mean $\mathrm{DBH}$, mean crown diameter, mean crown length, mean total height, crown surface area, live crown ratio, number of trees in competition, number of quadrants occupied, sum of competing basal areas, and sum of competing basal areas divided by distances. The mean variables were the averages between the first measurement and the last measurement. The resulting $\mathrm{R}^{2}$ values and levels of significance for yellow-poplar with linear regression equations are as follows:

Variable

$\mathrm{DBH}$

Crown diameter

Crown length

Crown surface area

Live crown ratio

Total height

Number of competing trees

$$
\mathbf{R}^{2} \text { value }
$$

0.62

0.23

0.58

negligible

0.41

0.05
Level of Significance **

$* *$

$* *$

$* *$

NS

$* *$

NS 
Number of occupied quadrants

Sum of competing basal areas

0.12

$* *$

Sum of competing basal areas / distances

0.27

$* *$

** Highly significant $(\mathrm{p}<.01)$

* Significant $(\mathrm{p}<.05)$

NS Not significant 


\section{CHAPTER 3: METHODS}

\section{Data}

The data were collected from existing CFI plots located in Central West Virginia (fig. 3.1).

Figure 3.1: Location map for the area of study.

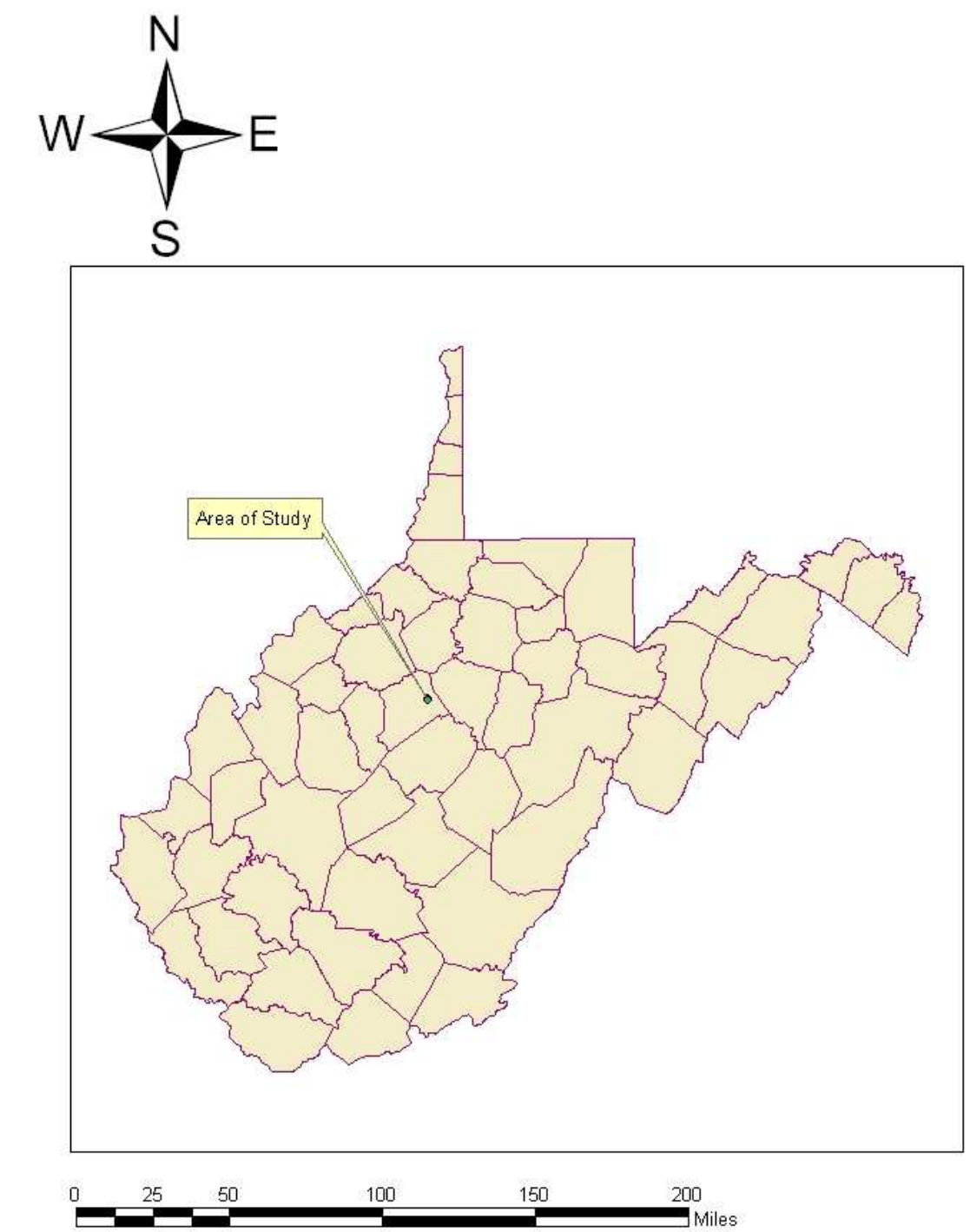


For this study, a 733-acre tract of second-growth forest was used. The tract was divided into compartments and subdivided into blocks. Within each block two to five CFI plots were established. The fixed-area CFI plots were one-tenth acre in size and were marked with an iron pipe in the center (fig. 3.2). The following data were recorded on most plots:

Tree number

Species

Diameter

Total height

Crown diameter

Age

Other data that was inconsistently measured included:

Height to a 4 inch top

Height to a 6 inch top

Height to an 8 inch top

Height to a 12 inch top

Form class

Bark thickness

Only trees with a DBH of five inches or larger were measured if they were within a 37.2 foot radius from the plot center. Each tree was numbered with paint for later recognition. The initial CFI plot inventory for this tract began around 1979. No specific time was set for remeasurements, although most of the plots had been remeasured at least once. The location of the CFI plots with reference to the block boundary was also mapped (fig. 3.2). 
Figure 3.2: Location of the CFI plots.

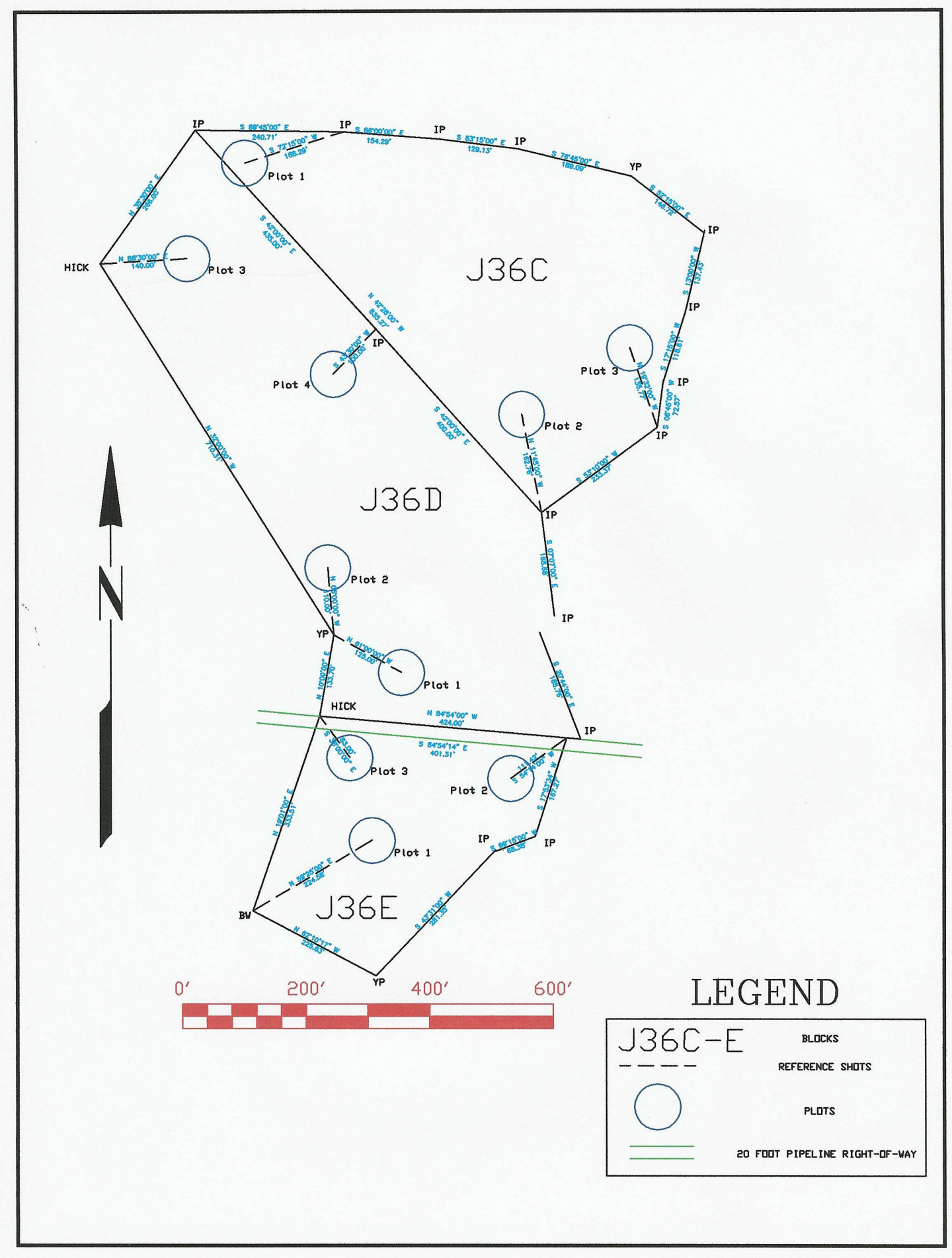


Some old aerial photographs were obtained from the years 1939, 1951, and 1958. In 1939 the area that was studied did not have any trees on it. In 1951 there were small trees all across the area and in 1958 there were medium sized trees. This information is in agreement with the data. When the first measurements were recorded around 1979, the approximate age of the stand was 31 years. There were several species associated with the yellow-poplar trees, however, the main species were Virginia pine (Pinus virginiana Mill.), hickory (Carya spp.), and sassafras (Sassafras albidum (Nutt.) Nees). As the years progressed, the Virginia pine and sassafras were out competed.

\section{Field Observations}

Diameter measurements of trees were taken with a diameter tape. The measurements were taken on the trunk at four and a half feet from the soil surface on the upslope side and were recorded to the nearest one-tenth inch (DBH). If the tree was less than five inches at this point it was not recorded. Total tree height measurements were recorded using a relascope. The crown diameters were obtained as an average of two measurements taken with a 100-foot tape. The first measurement was the largest diameter and the second was the smallest diameter of the crown. An increment borer was used to take a core sample at DBH. The core was placed in a straw for further analysis. The rings were counted on the core and the age was recorded. No additional years were added to account for the growth to breast height. All measurements were taken on standing trees. These measurements were taken at two different time periods on the CFI plots.

With emphasis on yellow-poplar, the CFI plots were first screened to find those plots containing the largest number of yellow-poplar trees. The next step was to examine 
the data and determine whether or not they were useable. Missing measurements or missing dates could render the data useless. CFI plots that showed the most potential were identified and reinventoried. Many tree numbers were not obtainable, which resulted in the elimination from further analysis. After a final examination of the data, reliable measurements taken from two time periods could be found for 69 yellow-poplar trees. These trees were distributed through ten CFI plots (fig. 3.3).

Figure 3.3: The number of yellow-poplar sample trees by plot number.

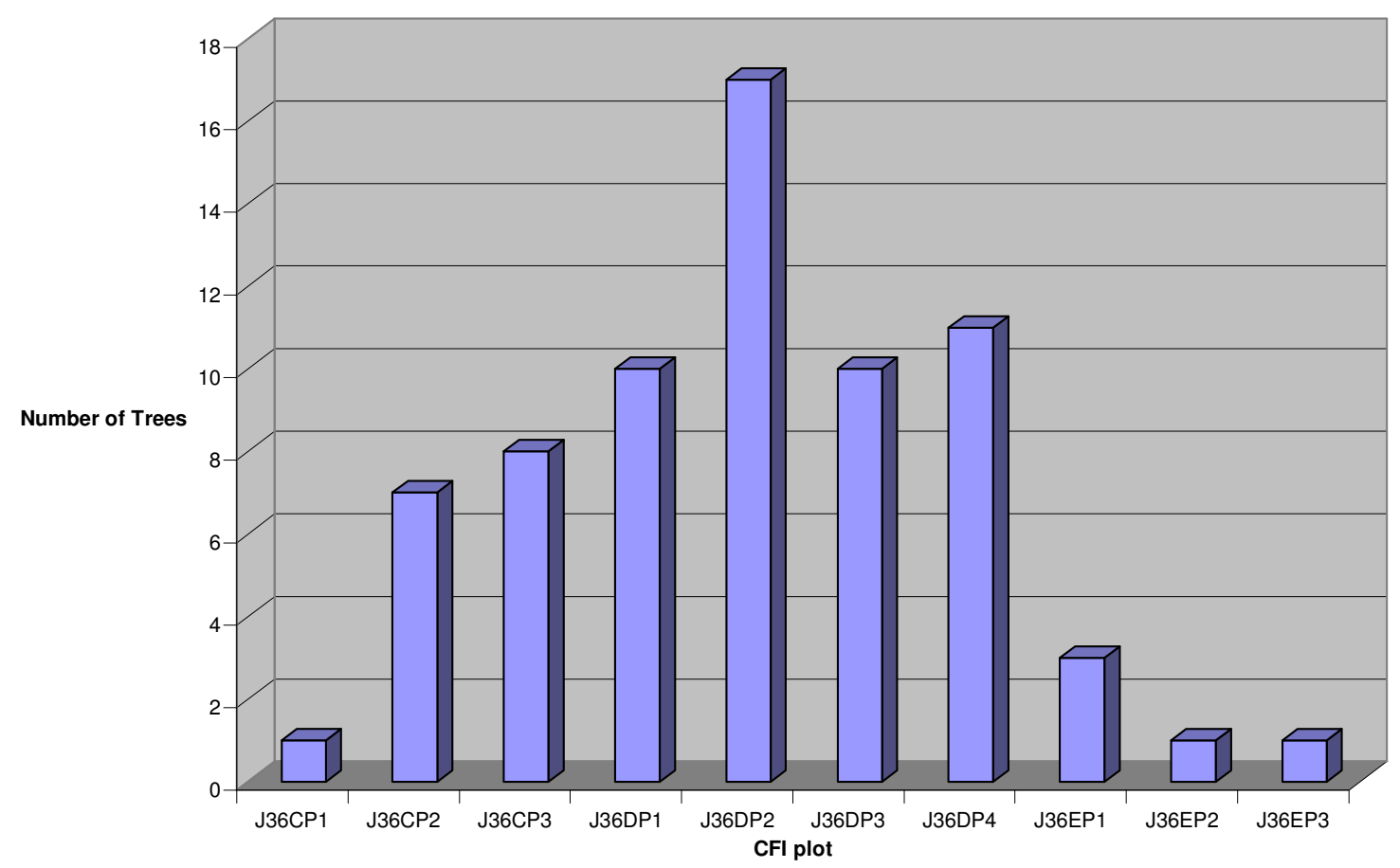

In the plot numbering system shown in Figure 3.3, the $\mathrm{J}$ represents Jakes Run which was the name for the tract. The 36 indicates compartments 3 and 6 combined. Next was the letter associated with the block and then the designated CFI plot number. 
These ten plots were relocated on the ground and the coordinates were obtained using a hand held global positioning system (GPS).

Table 3.1: Coordinates for each CFI center point in decimal degrees.

\begin{tabular}{|r|l|r|r|}
\hline NUMBER & NAME & LATITUDE & LONGITUDE \\
\hline 1 & J36CP1 & 38.96799 & -80.74576 \\
2 & J36CP2 & 38.96715 & -80.74421 \\
3 & J36CP3 & 38.96749 & -80.74352 \\
4 & J36DP1 & 38.96612 & -80.74476 \\
5 & J36DP2 & 38.96655 & -80.74506 \\
6 & J36DP3 & 38.9679 & -80.74606 \\
7 & J36DP4 & 38.96716 & -80.74477 \\
8 & J36EP1 & 38.96533 & -80.74469 \\
9 & J36EP2 & 38.96568 & -80.74398 \\
10 & J36EP3 & 38.96557 & -80.7449 \\
\hline
\end{tabular}

The information was put into a table (table 3.1) using Microsoft Excel and then added in ArcMap (ArcView 8 2002). ArcMap (ArcView 8 2002) was then used to obtain the aspect, slope position, and steepness associated with each of these CFI plots. This method was used because it produced more consistent results than field observations and was less time consuming. Slope position can be difficult to analyze without a relative knowledge of the distance from the bottom and top of the slope, which are not usually visible from the plot. Also the aspect is difficult to establish when plots are located on a spur or narrow draws. Thus, geographic information system (GIS) software was used to eliminate human error.

\section{Data Analysis}

The interval over which the two DBH measurements were collected did not occur over the same period for each tree. This time period varied between six and seven years. Because of this, basal area growth was expressed on a per year basis in order to facilitate comparisons to the other variables. The basal area growth per year (BAGY) was 
compared to the growth per year of total height, crown diameter, $\mathrm{DBH}$, and the averages of total height, crown diameter, $\mathrm{DBH}$, and age. The averages were calculated as the mean of the initial and final measurement.

Basal area per acre was calculated for each plot by summing the basal areas of each tree within the plot and then expanded to a per acre basis. Although border trees do not directly affect each of the study trees in a particular plot, it was assumed that plot basal area was a reasonable representation of the stand density of the area.

The trees per acre were calculated based on the number of trees in each plot that were five inches $\mathrm{DBH}$, or larger. BAGY was compared to the change in basal area per acre and trees per acre as well as the average basal area per acre and trees per acre. These averages were calculated as the mean of the beginning and ending measurement. The change was calculated as the difference between the final measurement and the beginning measurement. This was then placed on a per year basis by dividing that number by the years between these two measurements.

The topographic variables of aspect, steepness, and slope position were computed using ArcMap. All plot centers were established using a hand held GPS unit. A table of latitude and longitude values was imported into ArcMap (ArcView 8 2002) and placed over an elevation grid. Each cell of this grid represented about 9,688 square feet and contained a value associated with the elevation. The raster calculator was used to create aspect, steepness, and slope position grids. The grids were then reclassified to specification (Appendix B). The steepness and slope position were placed in three classes and the aspect was converted to a number based on the assumed site quality for 
that aspect with values ranging from zero to two. This number was calculated by using the cosine of the azimuth turned 45 degrees and then adding one:

$$
\text { Aspect }=[\cos (\text { Azimuth })]+1
$$

Figure 3.4: Values assigned to azimuths.

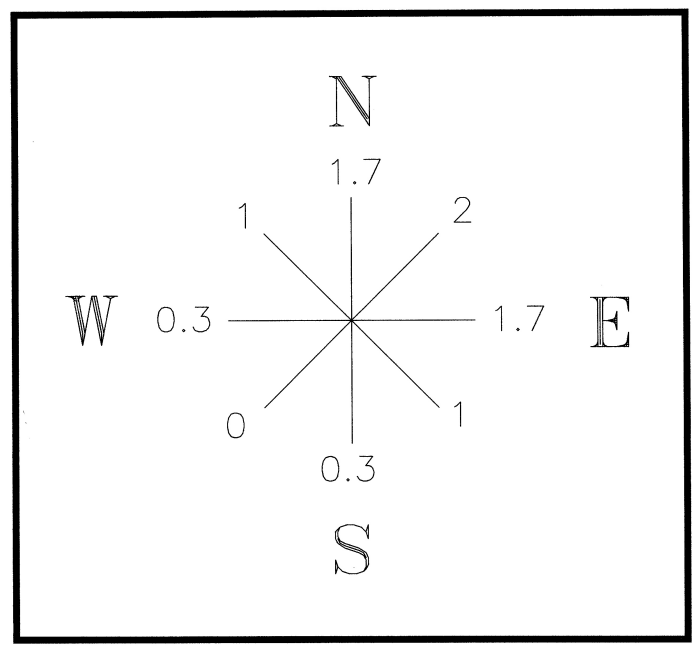

The turning of the azimuth assumes the best site to be at northeast and the poorest site to be at southwest. This formula resulted in values ranging from 0 to 2 .

Steepness was divided into three classifications based on the range of percent slope in the area. The observed percent slope ranged from near zero to approximately 55 percent. This was split into three equal classes and given dummy values of 0,1 , and 2 , with a higher value being associated with the less steep slopes which represent better sites (low=2, medium=1, high=0).

Slope position was also split into three categories based on the elevation of the surrounding area which included the top and bottom of the slope. The range in elevation was from 922 feet to 1,178 feet according to the elevation data obtained from the West Virginia State GIS Technical Center website (http://www.wvgis.wvu.edu). At the plot 
locations upper slopes were given a dummy value of 0 , mid-slopes a value of 1 and lower slopes representing the best sites were assigned a value of 2 .

A fourth topographic variable (landform) was based on the observed shape of the land where the CFI plot was located. These three shapes (spur/ridge, hillside, and draw/valley) were given dummy values according to their importance with yellow-poplar growth $($ spur/ridge $=0$, hillside $=1$, draw/valley $=2$ )

BAGY was compared to each of these and a combination of all four. The combination of these four variables, called total site (TS), could range from 0 (the worst site) to 8 (the best site). All of these comparisons were based on linear regressions and the $\mathrm{R}^{2}$ value was examined to determine the best relationship of a characteristic to basal area growth.

BAGY was also compared to the individual data sets to look for inconsistencies. Once the best relationship was found, based on the $\mathrm{R}^{2}$ value, the data were analyzed using SAS PROC REG (SAS v9.1 2004) to determine relationships and to test the significance of each relationship. All of the variables and the abbreviations associated with them can be found in Table 3.2. 
Table 3.2: Variables and their abbreviations.

\begin{tabular}{|l|l|}
\hline basal area growth per year & BAGY \\
\hline landform & LF \\
\hline aspect & ASP \\
\hline steepness & STP \\
\hline slope position & SP \\
\hline total site & TS \\
\hline diameter initial measurement & DBH1 \\
\hline crown diameter initial measurement & CD1 \\
\hline age initial measurement & A1 \\
\hline total height initial measurement & TH1 \\
\hline basal area per acre initial measurement & BAA1 \\
\hline trees per acre initial measurement & TPA1 \\
\hline diameter final measurement & DBH2 \\
\hline crown diameter final measurement & CD2 \\
\hline age final measurement & A2 \\
\hline total height final measurement & TH2 \\
\hline basal area per acre final measurement & BAA2 \\
\hline trees per acre final measurement & TPA2 \\
\hline change in basal area per acre per year & BAAGY \\
\hline change in trees per acre per year & TPAGY \\
\hline average basal area per acre & AVGBAA \\
\hline average trees per acre & AVGTPA \\
\hline diameter growth per year & DBHGY \\
\hline crown diameter growth per year & CDGY \\
\hline total height growth per year & THGY \\
\hline average diameter & AVGDBH \\
\hline average crown diameter & AVGCD \\
\hline average total height & AVGTH \\
\hline average age & AVGA \\
\hline
\end{tabular}




\section{CHAPTER 4: RESULTS}

\section{Topographic Factors}

All topographic factors were plotted against BAGY (Appendix C fig. A.1). Total site (TS) was also included which represents a combination of all four topographic factors. Next, the coefficient of determination $\left(\mathrm{R}^{2}\right)$ for each linear relationship was determined (table 4.1). Also, the significance of the relationship between BAGY and the variables was evaluated using the SAS PROC REG (SAS v9.1 2004) procedure (table 4.1).

Table 4.1: $\mathbf{R}^{2}$ values of topographic factors and topographic variable results from SAS using simple linear regression.

\begin{tabular}{|l|rrr|l|}
\hline Variable & $\mathbf{R}^{2}$ & & \multicolumn{1}{l|}{ Significance } & MSE \\
\hline Landform (LF) & & 0.0012 & $0.7732(\mathrm{NS})$ & 0.00029 \\
Aspect (ASP) & 0.0316 & $0.1439(\mathrm{NS})$ & 0.00028 \\
Steepness (STP) & 0.0001 & $0.9207(\mathrm{NS})$ & 0.00029 \\
Slope position (SP) & 0.0205 & $0.2411(\mathrm{NS})$ & 0.00028 \\
Total site (TS) & 0.00002 & $0.9681(\mathrm{NS})$ & 0.00029 \\
\hline
\end{tabular}

MSE is the mean squared error calculated using SAS. None of these variables proved to have a significant relationship with BAGY. Furthermore, combining them into the TS variable did not yield a significant relationship with BAGY.

\section{Competition Variables}

The relationship between basal area per acre and trees per acre was examined with respect to BAGY (Appendix C fig. A.2). Using a simple linear model, the basal area per acre for the first and second measurement periods (BAA1 and BAA2), trees per acre for the two periods (TPA1 and TPA2), average basal area per acre (AVGBAA), average trees per acre (AVGTPA), change in basal area per acre per year (BAAGY), and 
the change in trees per acre per year (TPAGY) were all examined with respect to BAGY (table 4.2).

Table 4.2: $\mathbf{R}^{2}$ values of competition variables using simple linear regression.

\begin{tabular}{|l|l|}
\hline Variables & $\mathbf{R}^{2}$ \\
\hline Basal area per acre initial measurement (BAA1) & 0.0067 \\
Trees per acre initial measurement (TPA1) & 0.0263 \\
Basal area per acre final measurement (BAA2) & 0.0018 \\
Trees per acre final measurement (TPA2) & 0.0328 \\
Average basal area per acre (AVGBAA) & 0.0037 \\
Average trees per acre (AVGTPA) & 0.0312 \\
Change in basal area per acre per year (BAAGY) & 0.0119 \\
Change in trees per acre per year (TPAGY) & 0.0155 \\
\hline
\end{tabular}

The comparison made with regard to data from the two measurement periods was to look for obvious inconsistencies. The other variables were examined further to check the significance of their relationship with BAGY (table 4.3).

Table 4.3: Competition variable results from SAS.

\begin{tabular}{|l|l|l|}
\hline Variables & Significance & MSE \\
\hline Change in trees per acre per year (TPAGY) & 0.3075 (NS) & 0.00029 \\
Change in basal area per acre per year (BAAGY) & 0.3732 (NS) & 0.00029 \\
Average basal area per acre (AVGBAA) & 0.6197 (NS) & 0.00029 \\
Average trees per acre (AVGTPA) & 0.1466 (NS) & 0.00028 \\
\hline
\end{tabular}

(NS) Model was not significant in a 95 percent confidence interval

All of these variables showed negligible slope coefficients and were not significantly related to BAGY.

For further analysis, the relationship between the competition indices $(\mathrm{y}=$ BAAGY and $\mathrm{x}=\mathrm{TPAGY}$ ) was examined. The values were examined on a per plot basis $\left(\mathrm{n}=10\right.$ ). The $\mathrm{R}^{2}$ value was 0.5342 (Appendix $\mathrm{C}$ fig. A.3). The beta 0 and beta 1 values were 2.3575 and 0.1789 . The MSE value was 0.2951 and the probability of a larger F was 0.0163 . The relationship was significant at the $(\mathrm{p}<.05)$ level and both parameters were significant with a 95 percent confidence interval (Appendix D p. 73). 


\section{Tree Characteristics}

Four tree characteristics (total height, age, crown diameter, and DBH) were compared to the BAGY. The average (AVG), change per year (GY), initial measurement (1), and final measurement (2) were all plotted against BAGY for comparison (Appendix C fig. A.4 - A.10). The resulting $\mathrm{R}^{2}$ values were calculated from a linear relationship (table 4.4).

Table 4.4: $\mathbf{R}^{2}$ values associated with the tree characteristics against basal area growth per year using simple linear regression.

\begin{tabular}{|l|r|}
\hline Variables & $\mathbf{R}^{2}$ \\
\hline Average age (AVGA) & 0.3137 \\
Average total height (AVGTH) & 0.1761 \\
Average crown diameter (AVGCD) & 0.5537 \\
Average diameter (AVGDBH) & 0.7515 \\
Total height growth per year (THGY) & 0.0565 \\
Crown diameter growth per year (CDGY) & 0.034 \\
Diameter growth per year (DBHGY) & 0.8698 \\
Age initial measurement (A1) & 0.3098 \\
Total height initial measurement (TH1) & 0.0405 \\
Crown diameter initial measurement (CD1) & 0.4685 \\
Diameter initial measurement (DBH1) & 0.655 \\
Age final measurement (A2) & 0.3174 \\
Total height final measurement (TH2) & 0.3364 \\
Crown diameter final measurement (CD2) & 0.5123 \\
Diameter final measurement (DBH2) & 0.8213 \\
\hline
\end{tabular}

The averages seemed to generally have higher $\mathrm{R}^{2}$ values than the changes per year, with the exception of DBH. The averages of the characteristics should give a good estimation of the tree characteristics half way through the growth period from the first to the final measurement. The average variables were then examined to see if their linear coefficients were significant and the following results were calculated (table 4.5). 
Table 4.5: Linear regression parameters for tree characteristics.

\begin{tabular}{|l|r|r|r|l|}
\hline Variables & \multicolumn{1}{l|}{$\begin{array}{l}\text { Estimated } \\
\text { b0 }\end{array}$} & $\begin{array}{l}\text { Estimated } \\
\text { b1 }\end{array}$ & Significance & \multicolumn{1}{l|}{ MSE } \\
\hline Average total height (AVGTH) & -0.0313 & 0.000806 & $0.0003^{* *}$ & 0.00024 \\
Average diameter (AVGDBH) & -0.0261 & 0.00569 & $<0.0001^{* *}$ & 0.00007 \\
Average crown diameter (AVGCD) & -0.0137 & 0.00212 & $<0.0001^{* *}$ & 0.00013 \\
Average age (AVGA) & -0.0298 & 0.00158 & $<0.0001^{* *}$ & 0.00020 \\
\hline
\end{tabular}

** Highly significant $(\mathrm{p}<.01)$

All models were highly significant $(\mathrm{p}<.01)$ and all parameter estimates for each model were significant at the 95 percent confidence level. 


\section{CHAPTER 5: DISCUSSION}

\section{Topographic Factors}

The topographic factors proved to have little or no correlation with basal area growth. This was also observed in other studies in the literature. Site class, slope, aspect, and elevation explained less than eight percent of the variation when compared to basal area growth in the study conducted by Poage and Tappeiner (2002). Total site factors only explained two to six percent of the variation when used to predict basal area growth according to Monserud and Sterba (1996).

McNab (1993) did find a correlation between landform index and terrain shape index when compared to the site index of yellow-poplar. However, site index as mentioned earlier is based on the dominant and codominant trees of the stand. This study looked at all the trees regardless of their crown class. Also this study showed a weaker relationship between total height and BAGY than the other three tree characteristics. This points to the fact that this study of all trees, regardless of crown class, may not be very comparable to studies dealing only with dominant or codominant trees.

The aspect variables appear to explain about three percent of the variation in BAGY and slope position appears to explain two percent of the variation. However, aspect shows a linear relationship of decreasing basal area growth with increasing aspect value. Slope position has the strongest positive relationship to BAGY of all the topographic features, even though it does not have a significant relationship $(\mathrm{p}<.05)$ with basal area growth. Although it was thought that the combination of these topographic factors may show a higher correlation with basal area growth than the individual variables, the opposite was true. The combination of these factors resulted in a 
weaker relationship with basal area growth than any of the variables had individually.

Landform seemed to have a slight association with BAGY. There was no linear relationship of slope steepness and total site to BAGY.

\section{Competition Variables}

The variables BAAGY (change in basal area per acre per year) and TPAGY (change in trees per acre per year) were similar in their relationships to basal area growth per year. The $\mathrm{R}^{2}$ values showed that about one percent of the variation in BAGY could be explained by each of these variables. Further analysis was completed on the comparison of these variables with each other. On a per plot basis the change in basal area per acre per year against the change in trees per acre per year resulted in an $\mathrm{R}^{2}$ value of 0.5342 . The $\mathrm{p}$-value was 0.0163 , which was significant $(\mathrm{p}<.05)$. Even though these two variables lack a significant correlation with basal area growth, they are significantly correlated with each other which stands to reason in unmanaged even-aged stands.

Barnes et al. (1998) stated that diameter growth is strongly influenced by density, which is usually measured by the number of trees or basal area per unit area. Schroder et al. (2002) indicated that competition should be a factor when estimating basal area growth. Why was there such a lack of correlation between these variables? One reason could be the method of measurement. The variables were calculated by taking the sum of each tree that was five inches DBH or larger and contained within the one-tenth-acre plot. This should have given an overall basal area per acre and trees per acre, but did not give a good estimate for the competition that each individual yellow-poplar tree within the plot was experiencing. Thus, a lack of correlation may be due to every tree within a certain plot is assumed to be influenced the same amount by the competition variable of that plot. 
Another reason might be that yellow-poplar trees typically grow faster in height than their competitors and the sample trees were probably mostly dominant or codominant. In this case, they are probably not competing as much for light as the other trees.

Gibbs (1969) measured competition differently. He used a prism to detect competing trees around a study tree. The larger the diameter of a tree the further it can be picked up and be counted as a competitor. This method proved to be more individualized toward the study tree than the plot method used in this study. The sum of competing basal areas and the sum of competing basal areas divided by their distances were both significant $(\mathrm{p}<.01)$ for yellow-poplar in Gibbs' study. However, the number of competing trees was not significant $(\mathrm{p}<.05)$ for yellow-poplar when compared to basal area growth.

\section{Tree Characteristics}

Of the tree characteristics, diameter had the best correlation, as expected. This is a result of $\mathrm{DBH}$ being used to compute basal area growth. The average $\mathrm{DBH}$ showed a linear relationship that explained 75 percent of the variation.

The next best linear relationship was with average crown diameter $\left(\mathrm{R}^{2}=0.5537\right)$. This relationship was explained in several different ways within the literature. One study explained that basal area growth increases with increasing crown size because of the mechanical stress on a tree's trunk (Dean, 2004). Barnes et al. (1998) stated that growth is related to the amount of hormones and photosynthate produced by the foliage. While these two factors make sense, the crown could also be a representation of the intensity of competition on a tree (after so many years). It could be assumed that more trees around a 
subject tree would hinder the expansion of its crown, which would in turn influence its physiological productivity and growth.

Average age versus basal area growth resulted in an $\mathrm{R}^{2}$ value of 0.3137 and a significant correlation $(\mathrm{p}<.01)$. It should be noted that this study did not limit the trees to dominant and codominant crown classes. The best relationship with age should result from using only dominant and codominant crown classes.

The literature on age relationships is mixed. Gibbs (1963) found no relationship between diameter and age in uneven-aged stands. Loewenstein et al. (2000) found a good relationship between age and diameter in an uneven-aged oak forest by fitting a sigmoidal curve. Probably the greatest difference between these two studies is that Gibbs (1963) used two inch diameter classes and Loewenstein et al. (2000) measured diameter to the nearest 0.5 centimeters.

The reason uneven-aged stands are usually avoided when looking for a relationship among variables associated with tree size is because of the ability of some species to exist for years in the understory without much growth. Yellow-poplar is a very intolerant species and therefore will not exist in these conditions. This eliminates some of the variability. Buckner and McCraken (1978) explain that yellow-poplar can even exist in a climax forest. The reason they proposed for this was related to the species ability to outgrow its competitors when seeded into large openings, often created by a large mature tree falling.

Average total height versus BAGY resulted in an $\mathrm{R}^{2}$ value of 0.1761 . This was much smaller than the other tree characteristics. Total height for the initial measurement had an $\mathrm{R}^{2}$ value of 0.0405 but the $\mathrm{R}^{2}$ value was 0.3364 for the heights taken at the final 
measurement. It can only be assumed that error in tree height measurement for the initial period caused the difference. However, the average of these two measurements when compared to BAGY still resulted in a significant $(\mathrm{p}<.01)$ relationship.

O’Brien et al. (1995) developed a curvilinear relationship between DBH and total height for eight neotropical tree species and had resulting $\mathrm{R}^{2}$ values range from 0.88 to 0.97. The average total height against basal area growth that Gibbs (1969) calculated had an $\mathrm{R}^{2}$ value of 0.41 . This further justifies the belief that some error occurred in the initial measuring of total height. Height can be a difficult measurement on large hardwood trees, as the forester is forced to sight through the crown to an assumed top of the tree. If the tree is leaning it further complicates the process.

Linear relationships might not be the best relationship between these variables and BAGY. Logrithmic, polynomial, power, and exponential regressions were all used on the relationship between BAGY and the following tree characteristics: AVGDBH, AVGTH, AVGCD, and AVGA. These provided only a slight increase in the $\mathrm{R}^{2}$ value, if any at all, with the exception of AVGTH. AVGTH had an $\mathrm{R}^{2}$ value of about .22 with both the power and exponential regressions. Since the power regression was a more simplistic equation of the two and the results were very similar, it was further evaluated using SAS PROC NLIN. SAS showed this new equation to have a p-value of <.0001, however, beta 0 was not significant (95\% confidence interval). When beta 0 was dropped from the equation, the relationship still had a p-value of <.0001 (Appendix D p. 81).

AVGDBH, AVGCD, AVGA and AVGTH were also used in a multiple regression equation to predict BAGY. The resulting equation had an $\mathrm{R}^{2}$ value of 0.81 with all beta 
values significant (95\% confidence interval) (Appendix D p. 82). The p-value for this equation was $<.0001$.

$\mathrm{BAGY}=\mathrm{b} 0+\mathrm{b} 1(\mathrm{AVGDBH})+\mathrm{b} 2(\mathrm{AVGCD})+\mathrm{b} 3(\mathrm{AVGA})+\mathrm{b} 4(\mathrm{AVGTH})$

Where:

$\mathrm{b} 0=-0.0563$

$\mathrm{b} 1=0.00333$

$\mathrm{b} 2=0.000808$

b3 $=0.000409$

$\mathrm{b} 4=0.000335$

The residuals of this equation were plotted and showed that most of the estimates fell within plus or minus 0.01 square foot of basal area growth per year of the actual values (Appendix C fig. A.11 - A.15). The $\mathrm{R}^{2}$ value did not increase by taking AVGTH out of the equation.

The $\mathrm{R}^{2}$ for average DBH with BAGY in this study equals 0.75 as compared to Gibbs (1969) $\mathrm{R}^{2}=0.70$; and average crown diameter $\mathrm{R}^{2}$ value equals 0.55 , as compared to Gibbs (1969) $\mathrm{R}^{2}=0.62$. These values seem to be fairly consistent in comparison. It should be noted that, overall, data from the final measurement had slightly higher $\mathrm{R}^{2}$ values with BAGY than data from the initial measurement period. It is logical to assume that individual tree measurements are better at predicting past basal area growth than future growth. It is also very obvious that individual tree measurements explain more about basal area growth than generalized site characteristics. 


\section{CHAPTER 6: CONCLUSION / COMMENTS}

\section{Topographic Factors}

The site characteristics did not have a significant correlation $(\mathrm{p}<.05)$ with basal area growth per year. Several recommendations could be made to try to correct this problem.

1. Try to make the data as specific to the subject trees as possible. For example perhaps actual elevations would have yielded better results than the coded slope positions.

2. The data need to be more uniform. Four plots contained ten or more trees and three plots contained only one tree. This was a limitation of the overall data set, but it results in some plots having one topographic variable to account for ten different trees and other plots have one topographic variable to compare to one tree.

3. Try to obtain a more uniform distribution of trees over the different variables. This is frequently a problem with biological data sets. It is difficult to find as many yellow-poplar trees growing on southwest aspects as compared to northeast aspects in a given area. This can result in trying to eliminate some of the study trees on the northeast aspect. Most researchers are reluctant to remove plots from the data set, so it ends up being skewed, like the present study. Another option is to eliminate the classes of the variable where fewer study trees exist.

\section{Competition Variables}

The competition variables did not have a significant correlation $(\mathrm{p}<.05)$ with BAGY. They did, however, have a significant correlation $(\mathrm{p}<.05)$ with each other. The 
lack of relationship is most likely a function of the method used to account for competition than to the lack of a relationship. The recommendation is to make the measure of competition more individualized to the study tree. Gibbs (1969) provides an example of measuring competition variables on an individual tree basis. While two of his competition variables were significant $(\mathrm{p}<.01)$, a third (number of competing trees) was not significant $(\mathrm{p}<.05)$.

\section{Tree Characteristics}

All of the tree characteristics proved to have a significant relationship with BAGY. Average DBH, average age, and average crown diameter all had a p-value of $<.0001$ and average tree height had a p-value of 0.0003 . It was proposed that average tree height could have a better correlation if the initial height measurements were more accurate. There was a better correlation among the tree characteristic variables with BAGY than the site characteristic variables because they are on an individual tree basis. Other studies predicting basal area growth have had similar results (Monserud and Sterba, 1996; Gibbs, 1969). Also, a higher correlation would probably exist if the study only used dominant and codominant trees.

The results did indicate that $\mathrm{DBH}$ had the highest $\mathrm{R}^{2}$ value, which was expected since basal area is a function of DBH squared. Crown diameter also showed a high correlation. All the tree characteristics showed a positive relationship with BAGY. This proves that trees which have a history of good growth continue to grow fast and trees that have larger crowns will grow faster. It also has implications that management practices that increase crown growing space will increase basal area growth. Some of these management practices are thinnings, crop tree release, or any timber stand improvement 
that would open up the canopy. It is important that there is not too much light on the trunks, as this would result in epicormic branching which lowers the timber value. Another disadvantage in opening up the canopy would be more movement in the upper portion of the tree, which could result in broken tops. This can only be avoided by choosing the proper trees to be released. There is a fine line between maximizing DBH growth and maximizing quality. It is important to invest in the trees that have good form and are fast growers, so they will continue in this trend.

\section{Other Objectives}

CFI data, such as this, did not have enough individualized variables to produce a basal area growth prediction model. While the tree characteristics were accurate enough, the topographic factors and competition variables were too generalized.

In the past, topographic variables were acquired by using tapes, clinometers, Abney levels, and compasses (McNab, 1987; Munn and Vimmerstedt, 1980). The topographic variables used in this paper were calculated using GIS. This is not only easier but it eliminates human bias.

GIS is a powerful tool that can be used to compute many topographic variables from latitude and longitude coordinates. This data set was completed using a raster image made up of 30 meter by 30 meter grid squares. However, technology is increasing and with the increasing speed of computers and light detection and ranging (LiDAR) data it will be possible to compute these variables on one square meter of ground as long as the coordinates are as accurate. The world of forestry will have many uses for this new technology. 


\section{REFERENCES}

ArcView 8 2002, ESRI (Environmental Systems Research Institute, Inc.), Redlands, CA, Est. 1969

Auten, J. T. 1945. Prediction of Site Index for Yellow Poplar from Soil and Topography. Journal of Forestry 43, 662-668.

Barnes, B. V., Zak, D. R., Denton, S. R., Spurr, S. H. 1998. Forest Ecology. John Wiley \& Sons Inc., New York, NY.

Bragg, D. C. 2001. A local basal area adjustment for crown width prediction. Northern Journal of Applied Forestry 18(1): 22-28.

Brunori, A., Nair, P. K. R., Rockwood, D. L. 1995. Performance of two Eucalyptus species at different slope positions and aspects in a contour-ridge planting system in the Negev Desert of Israel. Forest Ecology and Management 75: 41-48.

Buckner, E., McCracken, W. 1978. Yellow-Poplar: A Component of Climax Forests?. Journal of Forestry July, 421-423.

Carmean, W. H. 1975. Forest site quality evaluation in the United States. Advances in Agronomy 27, 209-269.

Carmean, W. H., Hahn, J. T. 1983. Site Comparisons for Upland Oaks and YellowPoplar in the Central States. Journal of Forestry Nov., 736-739.

Dean, T. J. 2004. Basal area increment and growth efficiency as functions of canopy dynamics and stem mechanics. Forestry Science. 50(1): 106-116.

Fekedulegn, D., Hicks Jr., R. R., Colbert, J. J. 2002. Influence of topographic aspect, precipitation and drought on radial growth of four major tree species in an Appalachian watershed. Forest Ecology and Management 6094, 1-17. 
Frank Jr., P. S., Hicks Jr., R. R., Harner Jr., E. J. 1984. Biomass predicted by soil-site factors: a case study in north central West Virginia. Canadian Journal of Forest Research 14: 137-140.

Gibbs, C. B. 1963. Tree Diameter a poor indicator of age in West Virginia hardwoods. U. S. Forest Service Research Note NE-11, 4p.

Gibbs, C. B. 1969. The relationship of tree characteristics and competition to basal area growth in Appalachian hardwoods. Thesis, 210p.

Hicks Jr., R. R., and Frank Jr., P. S. 1984. Relationship of aspect to soil nutrients, species importance and biomass in a forested watershed in West Virginia. Forest Ecology and Management 8: 281-291.

Kenefic, L. S., Nyland, R. D. 1999. Sugar maple height-diameter and age-diameter relationships in an uneven-aged northern hardwood stand. Northern Journal of Applied Forestry 16(1): 43-47.

Leak, W. B. 1985. Yellow-poplar site quality related to slope type in mountainous terrain. Northern Journal of Applied Forestry 4: 189-192.

Loewenstein, E. F., Johnson, P. S., and Garrett, H. E. 2000. Age and diameter structure of a managed uneven-aged oak forest. Canadian Journal of Forest Research 30: 1060-1070.

McNab, W. H. 1987. Yellow-poplar site quality related to slope type in mountainous terrain. Northern Journal of Applied Forestry 4: 189-192.

McNab, W. H. 1989. Terrain Shape Index: Quantifying Effect of Minor Landforms on Tree Height. Forest Science 35, 91-104. 
McNab, W. H. 1993. A topographic index to quantify the effect of mesoscale landform on site productivity. Canadian Journal of Forest Research 23: 1100-1107.

Miller, G. W. 2000. Effect of crown growing space on the development of young hardwood crop trees. Northern Journal of Applied Forestry 17(1): 25-35.

Molecular Expressions: Tree Collection: Microscopy of Tree Thin Sections. 10 Nov. 2002<http://www.microscopy.fsu.edu/trees/pages/tulippoplar.html

Monserud, R. A., Sterba, H. 1996. A basal area increment model for individual trees growing in even- and uneven-aged forest stands in Austria. Forest Ecology and Management 80, 57-80.

Munn, L. C., Vimmerstedt, J. P. 1980. Predicting height growth of yellow-poplar from soils and topography in south eastern Ohio. Soil Science Society of America. Journal 44: 384-387.

O’Brien, S. T., Hubbell, S. P., Spiro, P., Condit, R., Foster, R. B. 1995. Diameter, height, crown, and age relationships in eight neotropical tree species. Ecology 76(6): 1926-1939.

Oliver, C. D., Larson, B. C. 1996. Forest Stand Dynamics. John Wiley \& Sons Inc., New York, NY.

Olson Jr., D. F. 1969. Silvical characteristics of yellow-poplar. USDA Forest Service Research Paper SE-48, 16p.

Ottorini, J. M., Goff, N. L., Cluzean, C. 1996. Relationships between crown dimensions and stem development in Fraxinus excelsior. Canadian Journal of Forest Research 26: 394-401. 
Phillips, J. J. 1996. Site index of yellow-poplar related to soil and topography in southern New Jersey. USDA Forest Service NEFES Research Paper NE-52, 10pp.

Poage, N. J., Tappeiner II, J. C. 2002. Long-term patterns of diameter and basal area growth of old-growth douglas-fir trees in western Oregon. Canadian Journal of Forest Research 32: 1232-1243.

SAS Institute Inc., 2002. SAS/STAT Online User's Guide, Version 9.0, SAS Institute Inc., Cary NC.

Schroder, J., Soalleiro, R. R., Alonso, G. G. 2002. An age-independent basal area increment model for maritime pine trees in northwestern Spain. Forest Ecology and Management. 157: 55-64,

Smith W. R., Farrar Jr., R. M., Murphy, P. A., Yeiser, J. L., Meldahl, R. S., Kush, J. S. 1992. Crown and basal area relationships of open-grown southern pines for modeling competition and growth. Canadian Journal of Forest Research 22: 341-347.

Stage, A. R. 1976. An expression for the effect of aspect, slope, and habitat type on tree growth. Forest Science 22: 475-460.

Strub, M. R., Vasey, R. B., Burkhart, H. E. 1975. Comparison of diameter growth and crown competition factor in loblolly pine plantations. Forest Science. 21: 427431.

U.S. Department of Agriculture. 1965. Silvics of Forest Trees of the United States. Washington: GPO. 244-245.

Van Lear, D. H., Hosner, J. F. 1967. Correlation of site index and soil mapping units: Poor for yellow-poplar in southwest Virginia. Journal of Forestry Jan., 22-24. 
West Virginia GIS Technical Center. 26 July 2004<http://www.wvgis.wvu.edu 


\section{APPENDIX A}

DATA 
Table A.1: Topographic Factors

\begin{tabular}{|c|c|c|c|c|c|c|c|c|c|c|c|c|}
\hline CFI PLOT & $\begin{array}{l}\text { TREE } \\
\text { NUMBER }\end{array}$ & SPECIAL SITE & LANDFORM & AZIMUTH & $\begin{array}{l}\text { ASPECT } \\
\text { DIRECTION }\end{array}$ & ASPECT & $\%$ SLOPE & $\begin{array}{l}\text { STEEPNESS } \\
\text { CLASS }\end{array}$ & STEEPNESS & $\begin{array}{l}\text { SLOPE } \\
\text { POSITION } \\
\text { CLASS }\end{array}$ & $\begin{array}{l}\text { SLOPE } \\
\text { POSITION }\end{array}$ & $\begin{array}{l}\text { TOTAL } \\
\text { SITE }\end{array}$ \\
\hline J36CP1 & 12 & top of spur & 0 & 146 & southeast & 0.8092 & 28 & medium & 1 & middle & 1 & 2.8092 \\
\hline J36CP2 & 1 & $\begin{array}{l}\text { close to } \\
\text { draw }\end{array}$ & 2 & 126 & southeast & 1.1564 & 15 & low & 2 & low & 2 & 7.1564 \\
\hline J36CP2 & 2 & $\begin{array}{l}\text { close to } \\
\text { draw }\end{array}$ & 2 & 126 & southeast & 1.1564 & 15 & low & 2 & low & 2 & 7.1564 \\
\hline J36CP2 & 3 & $\begin{array}{l}\text { close to } \\
\text { draw }\end{array}$ & 2 & 126 & southeast & 1.1564 & 15 & low & 2 & low & 2 & 7.1564 \\
\hline J36CP2 & 4 & $\begin{array}{l}\text { close to } \\
\text { draw }\end{array}$ & 2 & 126 & southeast & 1.1564 & 15 & low & 2 & low & 2 & 7.1564 \\
\hline J36CP2 & 6 & $\begin{array}{l}\text { close to } \\
\text { draw }\end{array}$ & 2 & 126 & southeast & 1.1564 & 15 & low & 2 & low & 2 & 7.1564 \\
\hline J36CP2 & 10 & $\begin{array}{l}\text { close to } \\
\text { draw }\end{array}$ & 2 & 126 & southeast & 1.1564 & 15 & low & 2 & low & 2 & 7.1564 \\
\hline J36CP2 & 14 & $\begin{array}{l}\text { close to } \\
\text { draw }\end{array}$ & 2 & 126 & southeast & 1.1564 & 15 & low & 2 & low & 2 & 7.1564 \\
\hline J36CP3 & 2 & in a draw & 2 & 204 & southwest & 0.0664 & 25 & medium & 1 & low & 2 & 5.0664 \\
\hline J36CP3 & 4 & in a draw & 2 & 204 & southwest & 0.0664 & 25 & medium & 1 & low & 2 & 5.0664 \\
\hline J36CP3 & 6 & in a draw & 2 & 204 & southwest & 0.0664 & 25 & medium & 1 & low & 2 & 5.0664 \\
\hline J36CP3 & 8 & in a draw & 2 & 204 & southwest & 0.0664 & 25 & medium & 1 & low & 2 & 5.0664 \\
\hline J36CP3 & 10 & in a draw & 2 & 204 & southwest & 0.0664 & 25 & medium & 1 & low & 2 & 5.0664 \\
\hline J36CP3 & 11 & in a draw & 2 & 204 & southwest & 0.0664 & 25 & medium & 1 & low & 2 & 5.0664 \\
\hline J36CP3 & 12 & in a draw & 2 & 204 & southwest & 0.0664 & 25 & medium & 1 & low & 2 & 5.0664 \\
\hline J36CP3 & 13 & in a draw & 2 & 204 & southwest & 0.0664 & 25 & medium & 1 & low & 2 & 5.0664 \\
\hline J36DP1 & 1 & hillside & 1 & 76 & east & 1.8572 & 29 & medium & 1 & high & 0 & 3.8572 \\
\hline J36DP1 & 2 & hillside & 1 & 76 & east & 1.8572 & 29 & medium & 1 & high & 0 & 3.8572 \\
\hline J36DP1 & 3 & hillside & 1 & 76 & east & 1.8572 & 29 & medium & 1 & high & 0 & 3.8572 \\
\hline J36DP1 & 5 & hillside & 1 & 76 & east & 1.8572 & 29 & medium & 1 & high & 0 & 3.8572 \\
\hline J36DP1 & 8 & hillside & 1 & 76 & east & 1.8572 & 29 & medium & 1 & high & 0 & 3.8572 \\
\hline J36DP1 & 12 & hillside & 1 & 76 & east & 1.8572 & 29 & medium & 1 & high & 0 & 3.8572 \\
\hline
\end{tabular}




\begin{tabular}{|c|c|c|c|c|c|c|c|c|c|c|c|c|}
\hline J36DP1 & 16 & hillside & 1 & 76 & east & 1.8572 & 29 & medium & 1 & high & 0 & 3.8572 \\
\hline J36DP1 & 19 & hillside & 1 & 76 & east & 1.8572 & 29 & medium & 1 & high & 0 & 3.8572 \\
\hline J36DP1 & 20 & hillside & 1 & 76 & east & 1.8572 & 29 & medium & 1 & high & 0 & 3.8572 \\
\hline J36DP1 & 21 & hillside & 1 & 76 & east & 1.8572 & 29 & medium & 1 & high & 0 & 3.8572 \\
\hline J36DP2 & 2 & hillside & 1 & 52 & northeast & 1.9925 & 36 & high & 0 & high & 0 & 2.9925 \\
\hline J36DP2 & 3 & hillside & 1 & 52 & northeast & 1.9925 & 36 & high & 0 & high & 0 & 2.9925 \\
\hline J36DP2 & 4 & hillside & 1 & 52 & northeast & 1.9925 & 36 & high & 0 & high & 0 & 2.9925 \\
\hline J36DP2 & 5 & hillside & 1 & 52 & northeast & 1.9925 & 36 & high & 0 & high & 0 & 2.9925 \\
\hline J36DP2 & 6 & hillside & 1 & 52 & northeast & 1.9925 & 36 & high & 0 & high & 0 & 2.9925 \\
\hline J36DP2 & 7 & hillside & 1 & 52 & northeast & 1.9925 & 36 & high & 0 & high & 0 & 2.9925 \\
\hline J36DP2 & 11 & hillside & 1 & 52 & northeast & 1.9925 & 36 & high & 0 & high & 0 & 2.9925 \\
\hline J36DP2 & 12 & hillside & 1 & 52 & northeast & 1.9925 & 36 & high & 0 & high & 0 & 2.9925 \\
\hline J36DP2 & 13 & hillside & 1 & 52 & northeast & 1.9925 & 36 & high & 0 & high & 0 & 2.9925 \\
\hline J36DP2 & 14 & hillside & 1 & 52 & northeast & 1.9925 & 36 & high & 0 & high & 0 & 2.9925 \\
\hline J36DP2 & 15 & hillside & 1 & 52 & northeast & 1.9925 & 36 & high & 0 & high & 0 & 2.9925 \\
\hline J36DP2 & 16 & hillside & 1 & 52 & northeast & 1.9925 & 36 & high & 0 & high & 0 & 2.9925 \\
\hline J36DP2 & 18 & hillside & 1 & 52 & northeast & 1.9925 & 36 & high & 0 & high & 0 & 2.9925 \\
\hline J36DP2 & 19 & hillside & 1 & 52 & northeast & 1.9925 & 36 & high & 0 & high & 0 & 2.9925 \\
\hline J36DP2 & 22 & hillside & 1 & 52 & northeast & 1.9925 & 36 & high & 0 & high & 0 & 2.9925 \\
\hline J36DP2 & 23 & hillside & 1 & 52 & northeast & 1.9925 & 36 & high & 0 & high & 0 & 2.9925 \\
\hline J36DP2 & 24 & hillside & 1 & 52 & northeast & 1.9925 & 36 & high & 0 & high & 0 & 2.9925 \\
\hline J36DP3 & 3 & hillside & 1 & 120 & southeast & 1.2588 & 28 & medium & 1 & middle & 1 & 4.2588 \\
\hline J36DP3 & 6 & hillside & 1 & 120 & southeast & 1.2588 & 28 & medium & 1 & middle & 1 & 4.2588 \\
\hline J36DP3 & 7 & hillside & 1 & 120 & southeast & 1.2588 & 28 & medium & 1 & middle & 1 & 4.2588 \\
\hline J36DP3 & 9 & hillside & 1 & 120 & southeast & 1.2588 & 28 & medium & 1 & middle & 1 & 4.2588 \\
\hline J36DP3 & 11 & hillside & 1 & 120 & southeast & 1.2588 & 28 & medium & 1 & middle & 1 & 4.2588 \\
\hline J36DP3 & 12 & hillside & 1 & 120 & southeast & 1.2588 & 28 & medium & 1 & middle & 1 & 4.2588 \\
\hline J36DP3 & 13 & hillside & 1 & 120 & southeast & 1.2588 & 28 & medium & 1 & middle & 1 & 4.2588 \\
\hline J36DP3 & 14 & hillside & 1 & 120 & southeast & 1.2588 & 28 & medium & 1 & middle & 1 & 4.2588 \\
\hline J36DP3 & 15 & hillside & 1 & 120 & southeast & 1.2588 & 28 & medium & 1 & middle & 1 & 4.2588 \\
\hline J36DP3 & 16 & hillside & 1 & 120 & southeast & 1.2588 & 28 & medium & 1 & middle & 1 & 4.2588 \\
\hline J36DP4 & 1 & hillside & 1 & 52 & northeast & 1.9925 & 21 & medium & 1 & middle & 1 & 4.9925 \\
\hline
\end{tabular}




\begin{tabular}{|c|c|c|c|c|c|c|c|c|c|c|c|c|}
\hline J36DP4 & 2 & hillside & 1 & 52 & northeast & 1.9925 & 21 & medium & 1 & middle & 1 & 4.9925 \\
\hline J36DP4 & 3 & hillside & 1 & 52 & northeast & 1.9925 & 21 & medium & 1 & middle & 1 & 4.9925 \\
\hline J36DP4 & 4 & hillside & 1 & 52 & northeast & 1.9925 & 21 & medium & 1 & middle & 1 & 4.9925 \\
\hline J36DP4 & 5 & hillside & 1 & 52 & northeast & 1.9925 & 21 & medium & 1 & middle & 1 & 4.9925 \\
\hline J36DP4 & 6 & hillside & 1 & 52 & northeast & 1.9925 & 21 & medium & 1 & middle & 1 & 4.9925 \\
\hline J36DP4 & 8 & hillside & 1 & 52 & northeast & 1.9925 & 21 & medium & 1 & middle & 1 & 4.9925 \\
\hline J36DP4 & 13 & hillside & 1 & 52 & northeast & 1.9925 & 21 & medium & 1 & middle & 1 & 4.9925 \\
\hline J36DP4 & 17 & hillside & 1 & 52 & northeast & 1.9925 & 21 & medium & 1 & middle & 1 & 4.9925 \\
\hline J36DP4 & 18 & hillside & 1 & 52 & northeast & 1.9925 & 21 & medium & 1 & middle & 1 & 4.9925 \\
\hline J36DP4 & 19 & hillside & 1 & 52 & northeast & 1.9925 & 21 & medium & 1 & middle & 1 & 4.9925 \\
\hline J36EP1 & 4 & hillside & 1 & 114 & southeast & 1.3584 & 37 & high & 0 & middle & 1 & 3.3584 \\
\hline J36EP1 & 10 & hillside & 1 & 114 & southeast & 1.3584 & 37 & high & 0 & middle & 1 & 3.3584 \\
\hline J36EP1 & 11 & hillside & 1 & 114 & southeast & 1.3584 & 37 & high & 0 & middle & 1 & 3.3584 \\
\hline J36EP2 & 4 & hillside & 1 & 111 & east & 0.4067 & 32 & medium & 1 & low & 2 & 4.4067 \\
\hline J36EP3 & 9 & hillside & 1 & 120 & southeast & 1.2588 & 38 & high & 0 & middle & 1 & 3.2588 \\
\hline
\end{tabular}

Table A.2: Initial Tree Measurements

\begin{tabular}{|l|r|r|l|r|r|r|r|r|}
\hline CFI PLOT & $\begin{array}{l}\text { TREE } \\
\text { NUMBER }\end{array}$ & DBH1 & BA1 & BAA1 & TPA1 & A1 & TH1 & CD1 \\
\hline J36CP1 & 12 & 9.9 & 0.534547 & 62.371 & 230 & 44 & 64 & 22 \\
\hline J36CP2 & 1 & 13.1 & 0.935961 & 69.844 & 170 & 25 & 73 & 29 \\
\hline J36CP2 & 2 & 5.2 & 0.147476 & 69.844 & 170 & 23 & 52 & 16 \\
\hline J36CP2 & 3 & 10.5 & 0.601304 & 69.844 & 170 & 30 & 63 & 25 \\
\hline J36CP2 & 4 & 6.9 & 0.259665 & 69.844 & 170 & 27 & 56 & 24 \\
\hline J36CP2 & 6 & 8.8 & 0.422358 & 69.844 & 170 & 30 & 59 & 24 \\
\hline J36CP2 & 10 & 7.9 & 0.340384 & 69.844 & 170 & 37 & 52 & 22 \\
\hline J36CP2 & 14 & 7.8 & 0.331821 & 69.844 & 170 & 20 & 49 & 21 \\
\hline J36CP3 & 2 & 10.4 & 0.589905 & 71.063 & 160 & 32 & 57 & 24 \\
\hline J36CP3 & 4 & 9 & 0.441774 & 71.063 & 160 & 36 & 47 & 20 \\
\hline J36CP3 & 6 & 9.4 & 0.481915 & 71.063 & 160 & 31 & 35 & 19 \\
\hline
\end{tabular}




\begin{tabular}{|c|c|c|c|c|c|c|c|c|}
\hline J36CP3 & 8 & 9.4 & 0.481915 & 71.063 & 160 & 34 & 47 & 22 \\
\hline J36CP3 & 10 & 10.2 & 0.567434 & 71.063 & 160 & 37 & 48 & 10 \\
\hline J36CP3 & 11 & 13.9 & 1.053767 & 71.063 & 160 & 39 & 72 & 30 \\
\hline J36CP3 & 12 & 7.9 & 0.340384 & 71.063 & 160 & 25 & 28 & 27 \\
\hline J36CP3 & 13 & 5.8 & 0.183473 & 71.063 & 160 & 30 & 37 & 23 \\
\hline J36DP1 & 1 & 9.1 & 0.451646 & 77.213 & 220 & 35 & 67 & 15 \\
\hline J36DP1 & 2 & 7.5 & 0.306788 & 77.213 & 220 & 28 & 79 & 13 \\
\hline J36DP1 & 3 & 11 & 0.659934 & 77.213 & 220 & 31 & 83 & 19 \\
\hline J36DP1 & 5 & 8.5 & 0.394052 & 77.213 & 220 & 34 & 70 & 15 \\
\hline J36DP1 & 8 & 10 & 0.5454 & 77.213 & 220 & 31 & 70 & 18 \\
\hline J36DP1 & 12 & 7 & 0.267246 & 77.213 & 220 & 38 & 75 & 19 \\
\hline J36DP1 & 16 & 8.7 & 0.412813 & 77.213 & 220 & 37 & 80 & 11 \\
\hline J36DP1 & 19 & 6.7 & 0.24483 & 77.213 & 220 & 22 & 67 & 14 \\
\hline J36DP1 & 20 & 5.8 & 0.183473 & 77.213 & 220 & 32 & 49 & 13 \\
\hline J36DP1 & 21 & 6.7 & 0.24483 & 77.213 & 220 & 33 & 69 & 10 \\
\hline J36DP2 & 2 & 7.7 & 0.323368 & 80.947 & 240 & 28 & 67 & 14 \\
\hline J36DP2 & 3 & 6 & 0.196344 & 80.947 & 240 & 25 & 66 & 10 \\
\hline J36DP2 & 4 & 5.9 & 0.189854 & 80.947 & 240 & 26 & 55 & 13 \\
\hline J36DP2 & 5 & 7.8 & 0.331821 & 80.947 & 240 & 26 & 77 & 15 \\
\hline J36DP2 & 6 & 8.2 & 0.366727 & 80.947 & 240 & 28 & 78 & 16 \\
\hline J36DP2 & 7 & 7.3 & 0.290644 & 80.947 & 240 & 31 & 72 & 15 \\
\hline J36DP2 & 11 & 6.6 & 0.237576 & 80.947 & 240 & 28 & 70 & 12 \\
\hline J36DP2 & 12 & 10.6 & 0.612811 & 80.947 & 240 & 32 & 80 & 24 \\
\hline J36DP2 & 13 & 5.5 & 0.164984 & 80.947 & 240 & 25 & 63 & 9 \\
\hline J36DP2 & 14 & 9 & 0.441774 & 80.947 & 240 & 25 & 75 & 12 \\
\hline J36DP2 & 15 & 5.7 & 0.1772 & 80.947 & 240 & 31 & 62 & 14 \\
\hline J36DP2 & 16 & 12.2 & 0.811773 & 80.947 & 240 & 31 & 86 & 25 \\
\hline J36DP2 & 18 & 14.4 & 1.130941 & 80.947 & 240 & 32 & 85 & 20 \\
\hline J36DP2 & 19 & 5.4 & 0.159039 & 80.947 & 240 & 29 & 69 & 11 \\
\hline J36DP2 & 22 & 5.4 & 0.159039 & 80.947 & 240 & 24 & 55 & 11 \\
\hline J36DP2 & 23 & 5.9 & 0.189854 & 80.947 & 240 & 26 & 62 & 13 \\
\hline J36DP2 & 24 & 6.8 & 0.252193 & 80.947 & 240 & 21 & 70 & 13 \\
\hline
\end{tabular}




\begin{tabular}{|c|c|c|c|c|c|c|c|c|}
\hline J36DP3 & 3 & 6.6 & 0.237576 & 54.999 & 180 & 28 & 69 & 11 \\
\hline J36DP3 & 6 & 6.6 & 0.237576 & 54.999 & 180 & 30 & 71 & 15 \\
\hline J36DP3 & 7 & 5.9 & 0.189854 & 54.999 & 180 & 29 & 54 & 16 \\
\hline J36DP3 & 9 & 9.7 & 0.513167 & 54.999 & 180 & 31 & 70 & 20 \\
\hline J36DP3 & 11 & 6.7 & 0.24483 & 54.999 & 180 & 21 & 62 & 12 \\
\hline J36DP3 & 12 & 8.6 & 0.403378 & 54.999 & 180 & 37 & 70 & 20 \\
\hline J36DP3 & 13 & 5.7 & 0.1772 & 54.999 & 180 & 23 & 66 & 11 \\
\hline J36DP3 & 14 & 6 & 0.196344 & 54.999 & 180 & 30 & 66 & 12 \\
\hline J36DP3 & 15 & 6.1 & 0.202943 & 54.999 & 180 & 34 & 64 & 9 \\
\hline J36DP3 & 16 & 6.2 & 0.209652 & 54.999 & 180 & 36 & 72 & 13 \\
\hline J36DP4 & 1 & 5.2 & 0.147476 & 59.838 & 190 & 30 & 61 & 14 \\
\hline J36DP4 & 2 & 5.8 & 0.183473 & 59.838 & 190 & 25 & 71 & 14 \\
\hline J36DP4 & 3 & 5.9 & 0.189854 & 59.838 & 190 & 29 & 67 & 10 \\
\hline J36DP4 & 4 & 6 & 0.196344 & 59.838 & 190 & 27 & 75 & 13 \\
\hline J36DP4 & 5 & 5.9 & 0.189854 & 59.838 & 190 & 33 & 64 & 11 \\
\hline J36DP4 & 6 & 6 & 0.196344 & 59.838 & 190 & 29 & 71 & 11 \\
\hline J36DP4 & 8 & 8 & 0.349056 & 59.838 & 190 & 29 & 79 & 16 \\
\hline J36DP4 & 13 & 7.5 & 0.306788 & 59.838 & 190 & 35 & 60 & 15 \\
\hline J36DP4 & 17 & 7.1 & 0.274936 & 59.838 & 190 & 24 & 65 & 15 \\
\hline J36DP4 & 18 & 5.5 & 0.164984 & 59.838 & 190 & 35 & 65 & 15 \\
\hline J36DP4 & 19 & 7.3 & 0.290644 & 59.838 & 190 & 33 & 70 & 17 \\
\hline J36EP1 & 4 & 11.9 & 0.772341 & 75.426 & 180 & 43 & 61 & 30 \\
\hline J36EP1 & 10 & 11 & 0.659934 & 75.426 & 180 & 52 & 53 & 29 \\
\hline J36EP1 & 11 & 11.2 & 0.68415 & 75.426 & 180 & 39 & 56 & 32 \\
\hline J36EP2 & 4 & 13.7 & 1.023661 & 64.491 & 170 & 44 & 66 & 23 \\
\hline J36EP3 & 9 & 10.5 & 0.601304 & 70.402 & 180 & 29 & 51 & 20 \\
\hline
\end{tabular}


Table A.3: Final Tree Measurements

\begin{tabular}{|c|c|c|c|c|c|c|c|c|}
\hline CFI PLOT & $\begin{array}{l}\text { TREE } \\
\text { NUMBER }\end{array}$ & DBH2 & BA2 & BAA2 & TPA2 & A2 & TH2 & CD2 \\
\hline J36CP1 & 12 & 12.1 & 0.79852 & 75.968 & 240 & 50 & 83 & 39 \\
\hline J36CP2 & 1 & 14.6 & 1.162575 & 86.285 & 180 & 31 & 79 & 42 \\
\hline J36CP2 & 2 & 6.6 & 0.237576 & 86.285 & 180 & 29 & 55 & 24 \\
\hline J36CP2 & 3 & 12.2 & 0.811773 & 86.285 & 180 & 36 & 63 & 32 \\
\hline J36CP2 & 4 & 7.4 & 0.298661 & 86.285 & 180 & 33 & 63 & 19 \\
\hline J36CP2 & 6 & 10.2 & 0.567434 & 86.285 & 180 & 36 & 64 & 32 \\
\hline J36CP2 & 10 & 9.3 & 0.471716 & 86.285 & 180 & 43 & 59 & 17 \\
\hline J36CP2 & 14 & 10 & 0.5454 & 86.285 & 180 & 26 & 62 & 24 \\
\hline J36CP3 & 2 & 12.2 & 0.811773 & 77.081 & 130 & 38 & 85 & 23 \\
\hline J36CP3 & 4 & 10.1 & 0.556363 & 77.081 & 130 & 42 & 70 & 15 \\
\hline J36CP3 & 6 & 10.7 & 0.624428 & 77.081 & 130 & 37 & 69 & 15 \\
\hline J36CP3 & 8 & 10.8 & 0.636155 & 77.081 & 130 & 40 & 69 & 16 \\
\hline J36CP3 & 10 & 11.2 & 0.68415 & 77.081 & 130 & 43 & 83 & 12 \\
\hline J36CP3 & 11 & 16.7 & 1.521066 & 77.081 & 130 & 45 & 90 & 30 \\
\hline J36CP3 & 12 & 8 & 0.349056 & 77.081 & 130 & 31 & 46 & 15 \\
\hline J36CP3 & 13 & 6.7 & 0.24483 & 77.081 & 130 & 36 & 55 & 20 \\
\hline J36DP1 & 1 & 10.8 & 0.636155 & 90.085 & 200 & 41 & 80 & 17 \\
\hline J36DP1 & 2 & 8.1 & 0.357837 & 90.085 & 200 & 34 & 72 & 11.5 \\
\hline J36DP1 & 3 & 12.4 & 0.838607 & 90.085 & 200 & 37 & 75 & 19 \\
\hline J36DP1 & 5 & 10.6 & 0.612811 & 90.085 & 200 & 40 & 68 & 16.5 \\
\hline J36DP1 & 8 & 12.6 & 0.865877 & 90.085 & 200 & 37 & 77 & 18 \\
\hline J36DP1 & 12 & 8.7 & 0.412813 & 90.085 & 200 & 44 & 69 & 15.5 \\
\hline J36DP1 & 16 & 10.9 & 0.64799 & 90.085 & 200 & 43 & 81 & 19 \\
\hline J36DP1 & 19 & 7.8 & 0.331821 & 90.085 & 200 & 28 & 62 & 14.5 \\
\hline J36DP1 & 20 & 6.8 & 0.252193 & 90.085 & 200 & 38 & 54 & 16 \\
\hline J36DP1 & 21 & 7.5 & 0.306788 & 90.085 & 200 & 39 & 69 & 12 \\
\hline J36DP2 & 2 & 8.3 & 0.375726 & 102.653 & 250 & 34 & 68 & 13.5 \\
\hline J36DP2 & 3 & 6.4 & 0.223396 & 102.653 & 250 & 31 & 63 & 10.5 \\
\hline J36DP2 & 4 & 6.1 & 0.202943 & 102.653 & 250 & 32 & 70 & 14 \\
\hline
\end{tabular}




\begin{tabular}{|c|c|c|c|c|c|c|c|c|}
\hline J36DP2 & 5 & 8.9 & 0.432011 & 102.653 & 250 & 32 & 68 & 15.5 \\
\hline J36DP2 & 6 & 9.6 & 0.502641 & 102.653 & 250 & 34 & 82 & 17 \\
\hline J36DP2 & 7 & 8.1 & 0.357837 & 102.653 & 250 & 37 & 78 & 12 \\
\hline J36DP2 & 11 & 7.4 & 0.298661 & 102.653 & 250 & 34 & 68 & 14.5 \\
\hline J36DP2 & 12 & 12.7 & 0.879676 & 102.653 & 250 & 38 & 74 & 24 \\
\hline J36DP2 & 13 & 5.8 & 0.183473 & 102.653 & 250 & 31 & 66 & 10.5 \\
\hline J36DP2 & 14 & 10.5 & 0.601304 & 102.653 & 250 & 31 & 74 & 16.5 \\
\hline J36DP2 & 15 & 5.9 & 0.189854 & 102.653 & 250 & 37 & 55 & 12.5 \\
\hline J36DP2 & 16 & 14.4 & 1.130941 & 102.653 & 250 & 37 & 82 & 26.5 \\
\hline J36DP2 & 18 & 16 & 1.396224 & 102.653 & 250 & 38 & 81 & 21 \\
\hline J36DP2 & 19 & 6.3 & 0.216469 & 102.653 & 250 & 35 & 70 & 14 \\
\hline J36DP2 & 22 & 6 & 0.196344 & 102.653 & 250 & 30 & 61 & 12.5 \\
\hline J36DP2 & 23 & 6.9 & 0.259665 & 102.653 & 250 & 32 & 64 & 12.5 \\
\hline J36DP2 & 24 & 8 & 0.349056 & 102.653 & 250 & 27 & 77 & 16.5 \\
\hline J36DP3 & 3 & 7.5 & 0.306788 & 70.897 & 190 & 34 & 74 & 13.5 \\
\hline J36DP3 & 6 & 7.6 & 0.315023 & 70.897 & 190 & 36 & 78 & 14 \\
\hline J36DP3 & 7 & 6.6 & 0.237576 & 70.897 & 190 & 35 & 75 & 16 \\
\hline J36DP3 & 9 & 11.7 & 0.746598 & 70.897 & 190 & 37 & 83 & 25 \\
\hline J36DP3 & 11 & 7.5 & 0.306788 & 70.897 & 190 & 27 & 66 & 15.5 \\
\hline J36DP3 & 12 & 10.5 & 0.601304 & 70.897 & 190 & 43 & 83 & 22 \\
\hline J36DP3 & 13 & 6.1 & 0.202943 & 70.897 & 190 & 29 & 72 & 10.5 \\
\hline J36DP3 & 14 & 7.2 & 0.282735 & 70.897 & 190 & 36 & 73 & 14 \\
\hline J36DP3 & 15 & 7 & 0.267246 & 70.897 & 190 & 40 & 74 & 19 \\
\hline J36DP3 & 16 & 7.7 & 0.323368 & 70.897 & 190 & 42 & 74 & 18 \\
\hline J36DP4 & 1 & 6.6 & 0.237576 & 69.947 & 180 & 36 & 60 & 12 \\
\hline J36DP4 & 2 & 6.8 & 0.252193 & 69.947 & 180 & 31 & 75 & 11 \\
\hline J36DP4 & 3 & 6.8 & 0.252193 & 69.947 & 180 & 35 & 68 & 12 \\
\hline J36DP4 & 4 & 6.7 & 0.24483 & 69.947 & 180 & 33 & 75 & 11 \\
\hline J36DP4 & 5 & 6.5 & 0.230432 & 69.947 & 180 & 39 & 63 & 12 \\
\hline J36DP4 & 6 & 6.9 & 0.259665 & 69.947 & 180 & 35 & 78 & 13 \\
\hline J36DP4 & 8 & 9.9 & 0.534547 & 69.947 & 180 & 35 & 79 & 18 \\
\hline J36DP4 & 13 & 9.4 & 0.481915 & 69.947 & 180 & 41 & 82 & 15 \\
\hline
\end{tabular}




\begin{tabular}{|r|r|r|r|r|r|r|r|r|} 
J36DP4 & 17 & 9.3 & 0.471716 & 69.947 & 180 & 30 & 74 & 15 \\
\hline J36DP4 & 18 & 7.2 & 0.282735 & 69.947 & 180 & 41 & 72 & 15 \\
\hline J36DP4 & 19 & 10.1 & 0.556363 & 69.947 & 180 & 39 & 70 & 19.5 \\
\hline J36EP1 & 4 & 14.9 & 1.210843 & 96.337 & 180 & 50 & 77 & 29 \\
\hline J36EP1 & 10 & 14.2 & 1.099745 & 96.337 & 180 & 59 & 79 & 29 \\
\hline J36EP1 & 11 & 13.8 & 1.03866 & 96.337 & 180 & 46 & 84 & 28 \\
\hline J36EP2 & 4 & 15.1 & 1.243567 & 84.312 & 210 & 51 & 77 & 21 \\
\hline J36EP3 & 9 & 12.9 & 0.9076 & 83.139 & 170 & 36 & 75 & 22.5 \\
\hline
\end{tabular}

Table A.4: Tree Characteristics

\begin{tabular}{|c|c|c|c|c|c|c|c|c|c|c|}
\hline CFI PLOT & $\begin{array}{l}\text { TREE } \\
\text { NUMBER }\end{array}$ & BAGY & A2-A1 & THGY & CDGY & DBHGY & AVGA & AVGTH & AVGCD & AVGDBH \\
\hline J36CP1 & 12 & 0.043996 & 6 & 3.166667 & 2.833333 & 0.366667 & 47 & 73.5 & 30.5 & 11 \\
\hline J36CP2 & 1 & 0.037769 & 6 & 1 & 2.166667 & 0.25 & 28 & 76 & 35.5 & 13.85 \\
\hline J36CP2 & 2 & 0.015017 & 6 & 0.5 & 1.333333 & 0.233333 & 26 & 53.5 & 20 & 5.9 \\
\hline J36CP2 & 3 & 0.035078 & 6 & 0 & 1.166667 & 0.283333 & 33 & 63 & 28.5 & 11.35 \\
\hline J36CP2 & 4 & 0.006499 & 6 & 1.166667 & -0.83333 & 0.083333 & 30 & 59.5 & 21.5 & 7.15 \\
\hline J36CP2 & 6 & 0.024179 & 6 & 0.833333 & 1.333333 & 0.233333 & 33 & 61.5 & 28 & 9.5 \\
\hline J36CP2 & 10 & 0.021889 & 6 & 1.166667 & -0.83333 & 0.233333 & 40 & 55.5 & 19.5 & 8.6 \\
\hline J36CP2 & 14 & 0.035596 & 6 & 2.166667 & 0.5 & 0.366667 & 23 & 55.5 & 22.5 & 8.9 \\
\hline J36CP3 & 2 & 0.036978 & 6 & 4.666667 & -0.16667 & 0.3 & 35 & 71 & 23.5 & 11.3 \\
\hline J36CP3 & 4 & 0.019098 & 6 & 3.833333 & -0.83333 & 0.183333 & 39 & 58.5 & 17.5 & 9.55 \\
\hline J36CP3 & 6 & 0.023752 & 6 & 5.666667 & -0.66667 & 0.216667 & 34 & 52 & 17 & 10.05 \\
\hline J36CP3 & 8 & 0.025707 & 6 & 3.666667 & -1 & 0.233333 & 37 & 58 & 19 & 10.1 \\
\hline J36CP3 & 10 & 0.019453 & 6 & 5.833333 & 0.333333 & 0.166667 & 40 & 65.5 & 11 & 10.7 \\
\hline J36CP3 & 11 & 0.077883 & 6 & 3 & 0 & 0.466667 & 42 & 81 & 30 & 15.3 \\
\hline J36CP3 & 12 & 0.001445 & 6 & 3 & -2 & 0.016667 & 28 & 37 & 21 & 7.95 \\
\hline J36CP3 & 13 & 0.010226 & 6 & 3 & -0.5 & 0.15 & 33 & 46 & 21.5 & 6.25 \\
\hline J36DP1 & 1 & 0.030751 & 6 & 2.166667 & 0.333333 & 0.283333 & 38 & 73.5 & 16 & 9.95 \\
\hline J36DP1 & 2 & 0.008508 & 6 & -1.16667 & -0.25 & 0.1 & 31 & 75.5 & 12.25 & 7.8 \\
\hline
\end{tabular}




\begin{tabular}{|c|c|c|c|c|c|c|c|c|c|c|}
\hline J36DP1 & 3 & 0.029779 & 6 & -1.33333 & 0 & 0.233333 & 34 & 79 & 19 & 11.7 \\
\hline J36DP1 & 5 & 0.03646 & 6 & -0.33333 & 0.25 & 0.35 & 37 & 69 & 15.75 & 9.55 \\
\hline J36DP1 & 8 & 0.053413 & 6 & 1.166667 & 0 & 0.433333 & 34 & 73.5 & 18 & 11.3 \\
\hline J36DP1 & 12 & 0.024261 & 6 & -1 & -0.58333 & 0.283333 & 41 & 72 & 17.25 & 7.85 \\
\hline J36DP1 & 16 & 0.039196 & 6 & 0.166667 & 1.333333 & 0.366667 & 40 & 80.5 & 15 & 9.8 \\
\hline J36DP1 & 19 & 0.014499 & 6 & -0.83333 & 0.083333 & 0.183333 & 25 & 64.5 & 14.25 & 7.25 \\
\hline J36DP1 & 20 & 0.011453 & 6 & 0.833333 & 0.5 & 0.166667 & 35 & 51.5 & 14.5 & 6.3 \\
\hline J36DP1 & 21 & 0.010326 & 6 & 0 & 0.333333 & 0.133333 & 36 & 69 & 11 & 7.1 \\
\hline J36DP2 & 2 & 0.008726 & 6 & 0.166667 & -0.08333 & 0.1 & 31 & 67.5 & 13.75 & 8 \\
\hline J36DP2 & 3 & 0.004509 & 6 & -0.5 & 0.083333 & 0.066667 & 28 & 64.5 & 10.25 & 6.2 \\
\hline J36DP2 & 4 & 0.002182 & 6 & 2.5 & 0.166667 & 0.033333 & 29 & 62.5 & 13.5 & 6 \\
\hline J36DP2 & 5 & 0.016698 & 6 & -1.5 & 0.083333 & 0.183333 & 29 & 72.5 & 15.25 & 8.35 \\
\hline J36DP2 & 6 & 0.022652 & 6 & 0.666667 & 0.166667 & 0.233333 & 31 & 80 & 16.5 & 8.9 \\
\hline J36DP2 & 7 & 0.011199 & 6 & 1 & -0.5 & 0.133333 & 34 & 75 & 13.5 & 7.7 \\
\hline J36DP2 & 11 & 0.010181 & 6 & -0.33333 & 0.416667 & 0.133333 & 31 & 69 & 13.25 & 7 \\
\hline J36DP2 & 12 & 0.044477 & 6 & -1 & 0 & 0.35 & 35 & 77 & 24 & 11.65 \\
\hline J36DP2 & 13 & 0.003082 & 6 & 0.5 & 0.25 & 0.05 & 28 & 64.5 & 9.75 & 5.65 \\
\hline J36DP2 & 14 & 0.026588 & 6 & -0.16667 & 0.75 & 0.25 & 28 & 74.5 & 14.25 & 9.75 \\
\hline J36DP2 & 15 & 0.002109 & 6 & -1.16667 & -0.25 & 0.033333 & 34 & 58.5 & 13.25 & 5.8 \\
\hline J36DP2 & 16 & 0.053195 & 6 & -0.66667 & 0.25 & 0.366667 & 34 & 84 & 25.75 & 13.3 \\
\hline J36DP2 & 18 & 0.044214 & 6 & -0.66667 & 0.166667 & 0.266667 & 35 & 83 & 20.5 & 15.2 \\
\hline J36DP2 & 19 & 0.009572 & 6 & 0.166667 & 0.5 & 0.15 & 32 & 69.5 & 12.5 & 5.85 \\
\hline J36DP2 & 22 & 0.006218 & 6 & 1 & 0.25 & 0.1 & 27 & 58 & 11.75 & 5.7 \\
\hline J36DP2 & 23 & 0.011635 & 6 & 0.333333 & -0.08333 & 0.166667 & 29 & 63 & 12.75 & 6.4 \\
\hline J36DP2 & 24 & 0.016144 & 6 & 1.166667 & 0.583333 & 0.2 & 24 & 73.5 & 14.75 & 7.4 \\
\hline J36DP3 & 3 & 0.011535 & 6 & 0.833333 & 0.416667 & 0.15 & 31 & 71.5 & 12.25 & 7.05 \\
\hline J36DP3 & 6 & 0.012908 & 6 & 1.166667 & -0.16667 & 0.166667 & 33 & 74.5 & 14.5 & 7.1 \\
\hline J36DP3 & 7 & 0.007954 & 6 & 3.5 & 0 & 0.116667 & 32 & 64.5 & 16 & 6.25 \\
\hline J36DP3 & 9 & 0.038905 & 6 & 2.166667 & 0.833333 & 0.333333 & 34 & 76.5 & 22.5 & 10.7 \\
\hline J36DP3 & 11 & 0.010326 & 6 & 0.666667 & 0.583333 & 0.133333 & 24 & 64 & 13.75 & 7.1 \\
\hline J36DP3 & 12 & 0.032988 & 6 & 2.166667 & 0.333333 & 0.316667 & 40 & 76.5 & 21 & 9.55 \\
\hline J36DP3 & 13 & 0.00429 & 6 & 1 & -0.08333 & 0.066667 & 26 & 69 & 10.75 & 5.9 \\
\hline
\end{tabular}




\begin{tabular}{|c|c|c|c|c|c|c|c|c|c|c|}
\hline J36DP3 & 14 & 0.014399 & 6 & 1.166667 & 0.333333 & 0.2 & 33 & 69.5 & 13 & 6.6 \\
\hline J36DP3 & 15 & 0.010717 & 6 & 1.666667 & 1.666667 & 0.15 & 37 & 69 & 14 & 6.55 \\
\hline J36DP3 & 16 & 0.018953 & 6 & 0.333333 & 0.833333 & 0.25 & 39 & 73 & 15.5 & 6.95 \\
\hline J36DP4 & 1 & 0.015017 & 6 & -0.16667 & -0.33333 & 0.233333 & 33 & 60.5 & 13 & 5.9 \\
\hline J36DP4 & 2 & 0.011453 & 6 & 0.666667 & -0.5 & 0.166667 & 28 & 73 & 12.5 & 6.3 \\
\hline J36DP4 & 3 & 0.01039 & 6 & 0.166667 & 0.333333 & 0.15 & 32 & 67.5 & 11 & 6.35 \\
\hline J36DP4 & 4 & 0.008081 & 6 & 0 & -0.33333 & 0.116667 & 30 & 75 & 12 & 6.35 \\
\hline J36DP4 & 5 & 0.006763 & 6 & -0.16667 & 0.166667 & 0.1 & 36 & 63.5 & 11.5 & 6.2 \\
\hline J36DP4 & 6 & 0.010553 & 6 & 1.166667 & 0.333333 & 0.15 & 32 & 74.5 & 12 & 6.45 \\
\hline J36DP4 & 8 & 0.030915 & 6 & 0 & 0.333333 & 0.316667 & 32 & 79 & 17 & 8.95 \\
\hline J36DP4 & 13 & 0.029188 & 6 & 3.666667 & 0 & 0.316667 & 38 & 71 & 15 & 8.45 \\
\hline J36DP4 & 17 & 0.032797 & 6 & 1.5 & 0 & 0.366667 & 27 & 69.5 & 15 & 8.2 \\
\hline J36DP4 & 18 & 0.019625 & 6 & 1.166667 & 0 & 0.283333 & 38 & 68.5 & 15 & 6.35 \\
\hline J36DP4 & 19 & 0.044286 & 6 & 0 & 0.416667 & 0.466667 & 36 & 70 & 18.25 & 8.7 \\
\hline J36EP1 & 4 & 0.062643 & 7 & 2.285714 & -0.14286 & 0.428571 & 46.5 & 69 & 29.5 & 13.4 \\
\hline J36EP1 & 10 & 0.06283 & 7 & 3.714286 & 0 & 0.457143 & 55.5 & 66 & 29 & 12.6 \\
\hline J36EP1 & 11 & 0.050644 & 7 & 4 & -0.57143 & 0.371429 & 42.5 & 70 & 30 & 12.5 \\
\hline J36EP2 & 4 & 0.031415 & 7 & 1.571429 & -0.28571 & 0.2 & 47.5 & 71.5 & 22 & 14.4 \\
\hline J36EP3 & 9 & 0.043757 & 7 & 3.428571 & 0.357143 & 0.342857 & 32.5 & 63 & 21.25 & 11.7 \\
\hline
\end{tabular}

Table A.5: Competition Variables

\begin{tabular}{|l|r|l|l|l|r|}
\hline CFI PLOT & $\begin{array}{l}\text { TREE } \\
\text { NUMBER }\end{array}$ & BAAGY & TPAGY & AVGBAA & AVGTPA \\
\hline J36CP1 & 12 & 2.266167 & 1.666667 & 69.1695 & 235 \\
\hline J36CP2 & 1 & 2.740167 & 1.666667 & 78.0645 & 175 \\
\hline J36CP2 & 2 & 2.740167 & 1.666667 & 78.0645 & 175 \\
\hline J36CP2 & 3 & 2.740167 & 1.666667 & 78.0645 & 175 \\
\hline J36CP2 & 4 & 2.740167 & 1.666667 & 78.0645 & 175 \\
\hline J36CP2 & 6 & 2.740167 & 1.666667 & 78.0645 & 175 \\
\hline J36CP2 & 10 & 2.740167 & 1.666667 & 78.0645 & 175 \\
\hline
\end{tabular}




\begin{tabular}{|l|r|r|r|r|r|} 
J36CP2 & 14 & 2.740167 & 1.666667 & 78.0645 & 175 \\
\hline J36CP3 & 2 & 1.003 & -5 & 74.072 & 145 \\
\hline J36CP3 & 4 & 1.003 & -5 & 74.072 & 145 \\
\hline J36CP3 & 6 & 1.003 & -5 & 74.072 & 145 \\
\hline J36CP3 & 8 & 1.003 & -5 & 74.072 & 145 \\
\hline J36CP3 & 10 & 1.003 & -5 & 74.072 & 145 \\
\hline J36CP3 & 11 & 1.003 & -5 & 74.072 & 145 \\
\hline J36CP3 & 12 & 1.003 & -5 & 74.072 & 145 \\
\hline J36CP3 & 13 & 1.003 & -5 & 74.072 & 145 \\
\hline J36DP1 & 1 & 2.145333 & -3.33333 & 83.649 & 210 \\
\hline J36DP1 & 2 & 2.145333 & -3.33333 & 83.649 & 210 \\
\hline J36DP1 & 3 & 2.145333 & -3.33333 & 83.649 & 210 \\
\hline J36DP1 & 5 & 2.145333 & -3.33333 & 83.649 & 210 \\
\hline J36DP1 & 8 & 2.145333 & -3.33333 & 83.649 & 210 \\
\hline J36DP1 & 12 & 2.145333 & -3.33333 & 83.649 & 210 \\
\hline J36DP1 & 16 & 2.145333 & -3.33333 & 83.649 & 210 \\
\hline J36DP1 & 19 & 2.145333 & -3.33333 & 83.649 & 210 \\
\hline J36DP1 & 20 & 2.145333 & -3.33333 & 83.649 & 210 \\
\hline J36DP1 & 21 & 2.145333 & -3.33333 & 83.649 & 210 \\
\hline J36DP2 & 2 & 3.617667 & 1.666667 & 91.8 & 245 \\
\hline J36DP2 & 3 & 3.617667 & 1.666667 & 91.8 & 245 \\
\hline J36DP2 & 4 & 3.617667 & 1.666667 & 91.8 & 245 \\
\hline J36DP2 & 5 & 3.617667 & 1.666667 & 91.8 & 245 \\
\hline J36DP2 & 6 & 3.617667 & 1.666667 & 91.8 & 245 \\
\hline J36DP2 & 7 & 3.617667 & 1.666667 & 91.8 & 245 \\
\hline J36DP2 & 11 & 3.617667 & 1.666667 & 91.8 & 245 \\
\hline J36DP2 & 12 & 3.617667 & 1.666667 & 91.8 & 245 \\
\hline J36DP2 & 13 & 3.617667 & 1.666667 & 91.8 & 245 \\
\hline J36DP2 & 14 & 3.617667 & 1.666667 & 91.8 & 245 \\
\hline J36DP2 & 15 & 3.617667 & 1.666667 & 91.8 & 245 \\
\hline J36DP2 & 16 & 3.617667 & 1.666667 & 91.8 & 245 \\
\hline J36DP2 & 18 & 3.617667 & 1.666667 & 91.8 & 245 \\
\hline
\end{tabular}




\begin{tabular}{|l|r|r|r|r|r|} 
J36DP2 & 19 & 3.617667 & 1.666667 & 91.8 & 245 \\
\hline J36DP2 & 22 & 3.617667 & 1.666667 & 91.8 & 245 \\
\hline J36DP2 & 23 & 3.617667 & 1.666667 & 91.8 & 245 \\
\hline J36DP2 & 24 & 3.617667 & 1.666667 & 91.8 & 245 \\
\hline J36DP3 & 3 & 2.649667 & 1.666667 & 62.948 & 185 \\
\hline J36DP3 & 6 & 2.649667 & 1.666667 & 62.948 & 185 \\
\hline J36DP3 & 7 & 2.649667 & 1.666667 & 62.948 & 185 \\
\hline J36DP3 & 9 & 2.649667 & 1.666667 & 62.948 & 185 \\
\hline J36DP3 & 11 & 2.649667 & 1.666667 & 62.948 & 185 \\
\hline J36DP3 & 12 & 2.649667 & 1.666667 & 62.948 & 185 \\
\hline J36DP3 & 13 & 2.649667 & 1.666667 & 62.948 & 185 \\
\hline J36DP3 & 14 & 2.649667 & 1.666667 & 62.948 & 185 \\
\hline J36DP3 & 15 & 2.649667 & 1.666667 & 62.948 & 185 \\
\hline J36DP3 & 16 & 2.649667 & 1.666667 & 62.948 & 185 \\
\hline J36DP4 & 1 & 1.684833 & -1.66667 & 64.8925 & 185 \\
\hline J36DP4 & 2 & 1.684833 & -1.66667 & 64.8925 & 185 \\
\hline J36DP4 & 3 & 1.684833 & -1.66667 & 64.8925 & 185 \\
\hline J36DP4 & 4 & 1.684833 & -1.66667 & 64.8925 & 185 \\
\hline J36DP4 & 5 & 1.684833 & -1.66667 & 64.8925 & 185 \\
\hline J36DP4 & 6 & 1.684833 & -1.66667 & 64.8925 & 185 \\
\hline J36DP4 & 8 & 1.684833 & -1.66667 & 64.8925 & 185 \\
\hline J36DP4 & 13 & 1.684833 & -1.66667 & 64.8925 & 185 \\
\hline J36DP4 & 17 & 1.684833 & -1.66667 & 64.8925 & 185 \\
\hline J36DP4 & 18 & 1.684833 & -1.66667 & 64.8925 & 185 \\
\hline J36DP4 & 19 & 1.684833 & -1.66667 & 64.8925 & 185 \\
\hline J36EP1 & 4 & 2.987286 & 0 & 85.8815 & 180 \\
\hline J36EP1 & 10 & 2.987286 & 0 & 85.8815 & 180 \\
\hline J36EP1 & 11 & 2.987286 & 0 & 85.8815 & 180 \\
\hline J36EP2 & 4 & 2.831571 & 5.714286 & 74.4015 & 190 \\
\hline J36EP3 & 9 & 1.819571 & -1.42857 & 76.7705 & 175 \\
\hline
\end{tabular}


APPENDIX B

GIS MAPS 

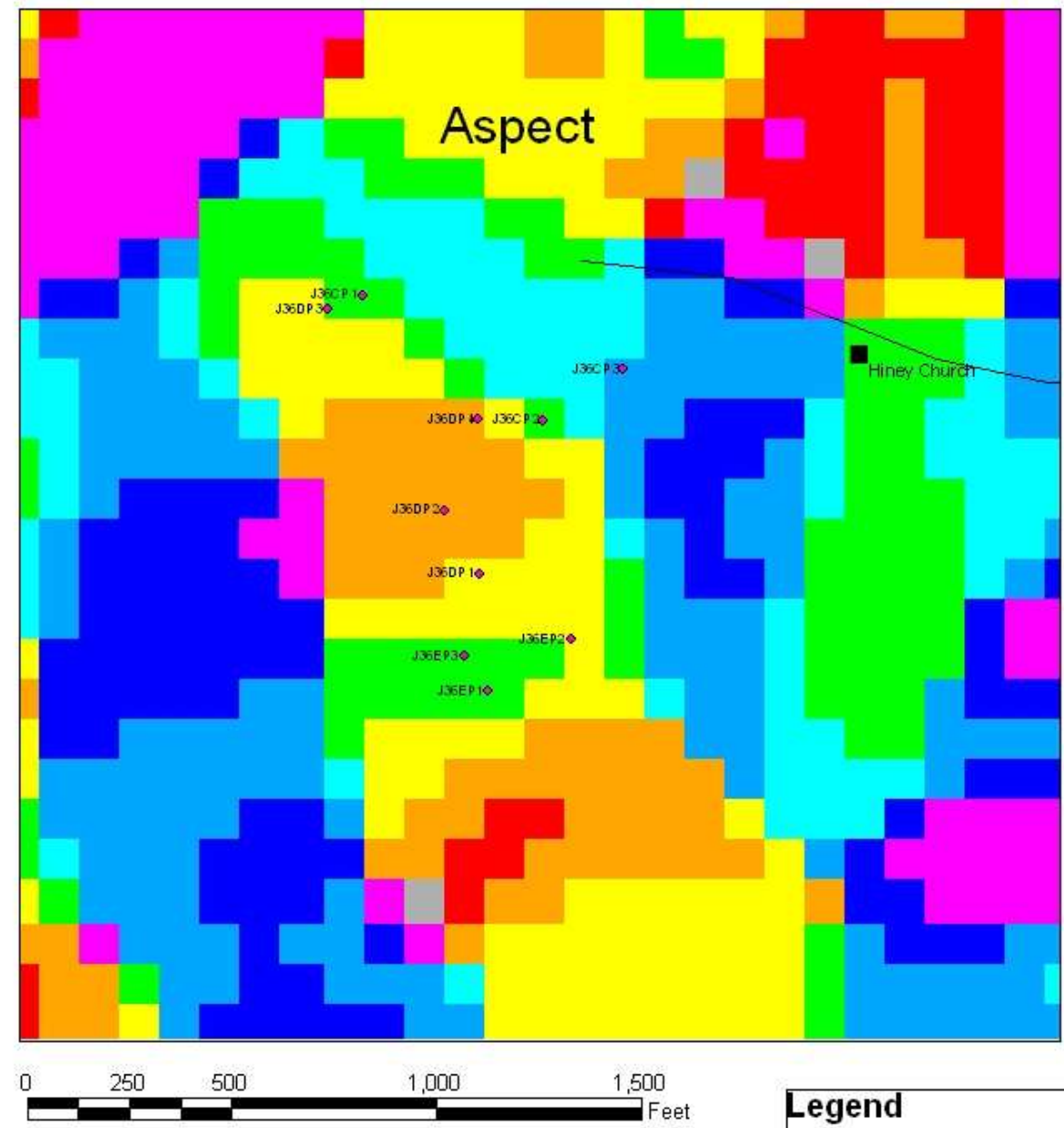

\begin{tabular}{l} 
Legend \\
Aspect \\
\hline \\
\hline \\
Flat \\
North (0-22.5) \\
Northeast (22.5-67.5) \\
East (67.5-112.5) \\
Southeast (112.5-157.5) \\
South (157 .5-202.5) \\
Southwest (202.5-247.5) \\
West(247.5-292.5) \\
Northwest (292.5-337.5) \\
North (337.5-360) \\
\hline
\end{tabular}

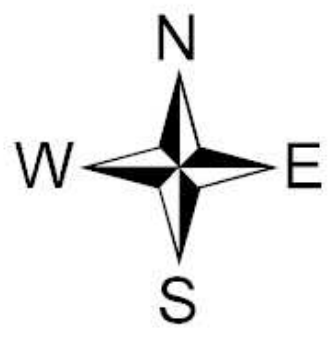




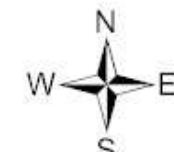

\section{Slope Position}

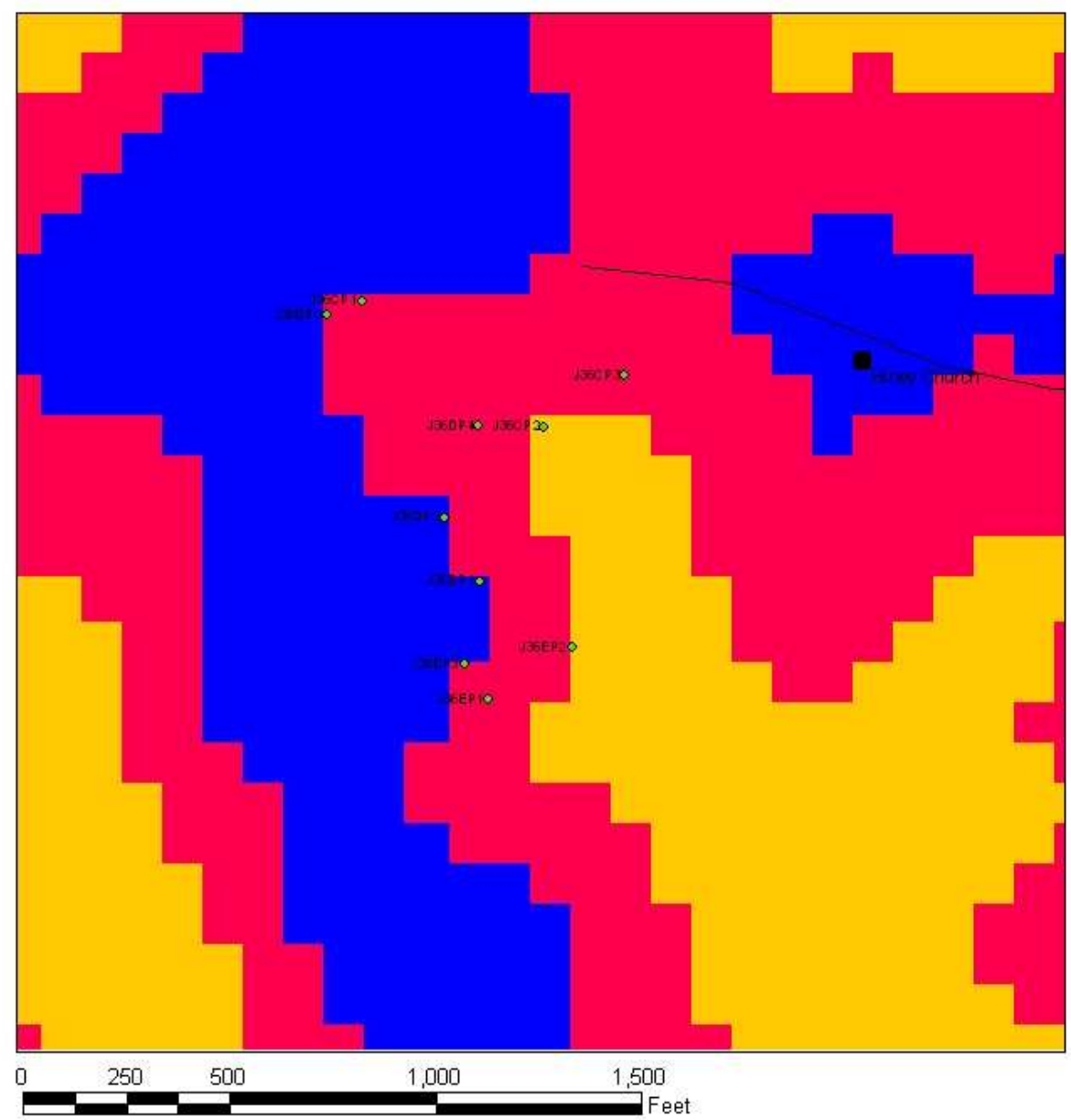

Chris Crum

July 26, 2004

\begin{tabular}{|l|}
\hline Legend \\
Slope Position \\
\hline \\
Low \\
\hline Middle \\
\hline High \\
\hline
\end{tabular}



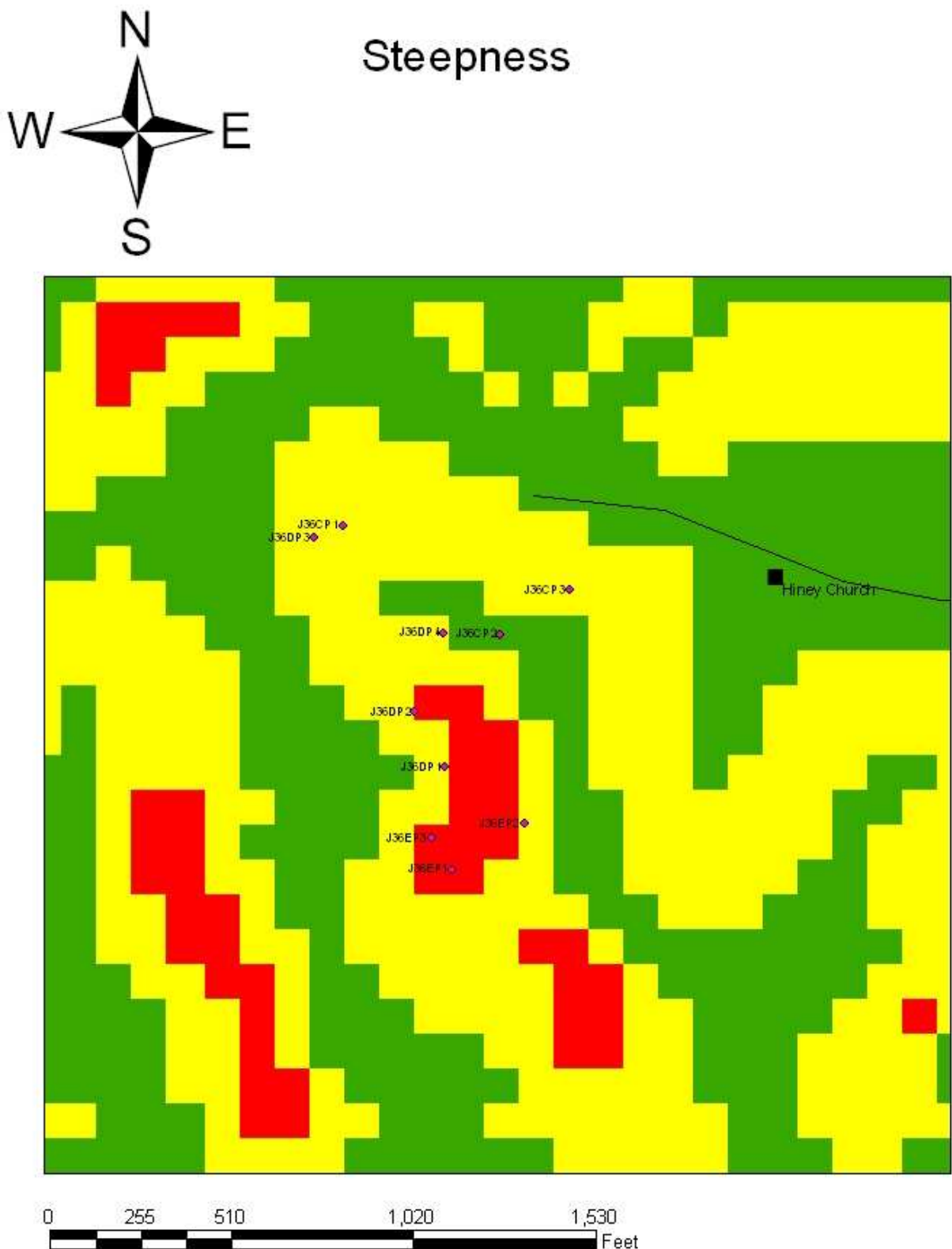

Chris Crum

July 26, 2004

Legend

Low

Medium

High 
APPENDIX C

GRAPHS 
Figure A.1: Basal Area Growth per Year Plotted Against Topographic Factors

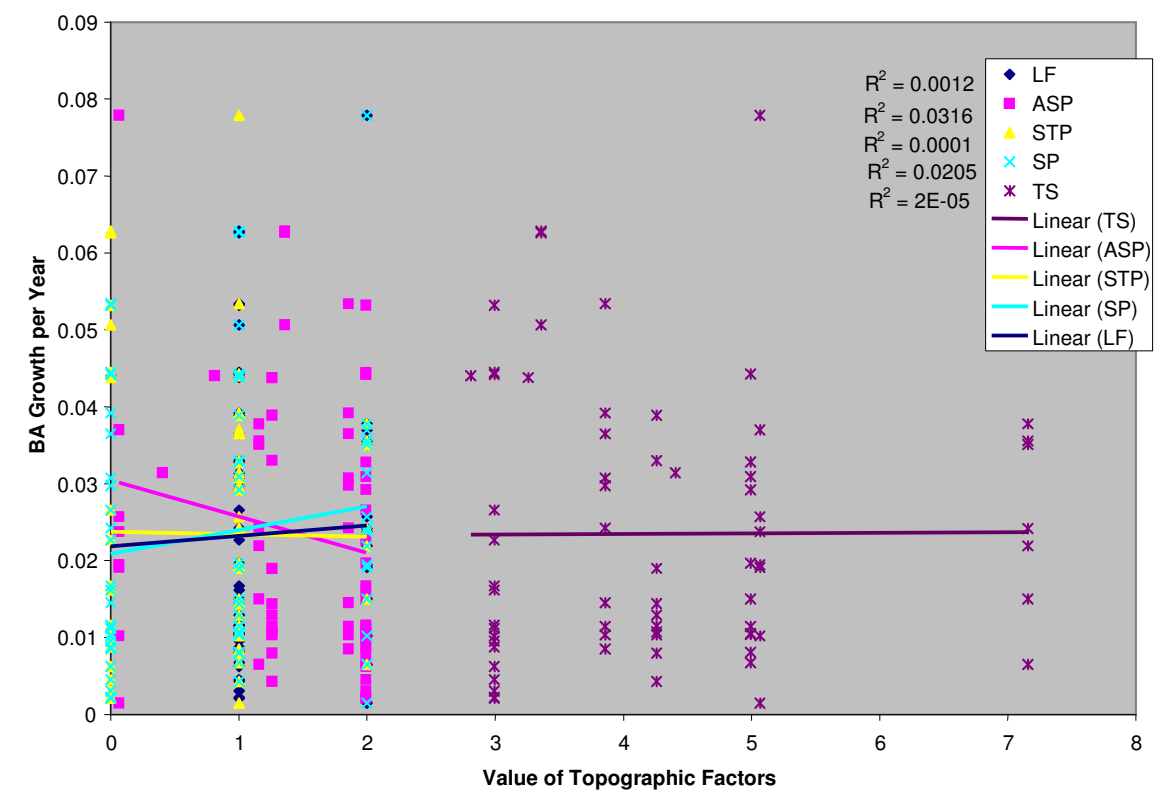

Figure A.2: Basal Area Growth per Year Plotted Against Basal Area per Acre and

\section{Trees per Acre}

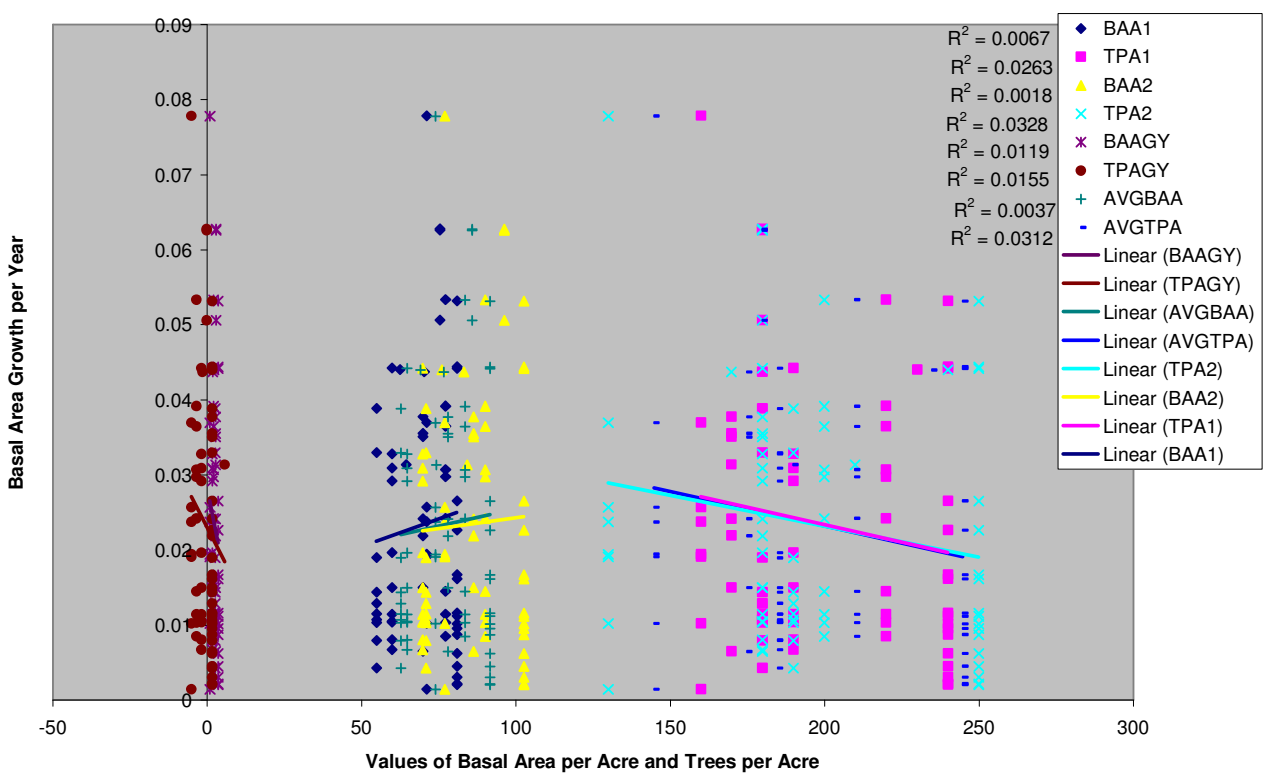


Figure A.3: Change in Basal Area per Acre per Year Versus Change in Trees per Acre per Year

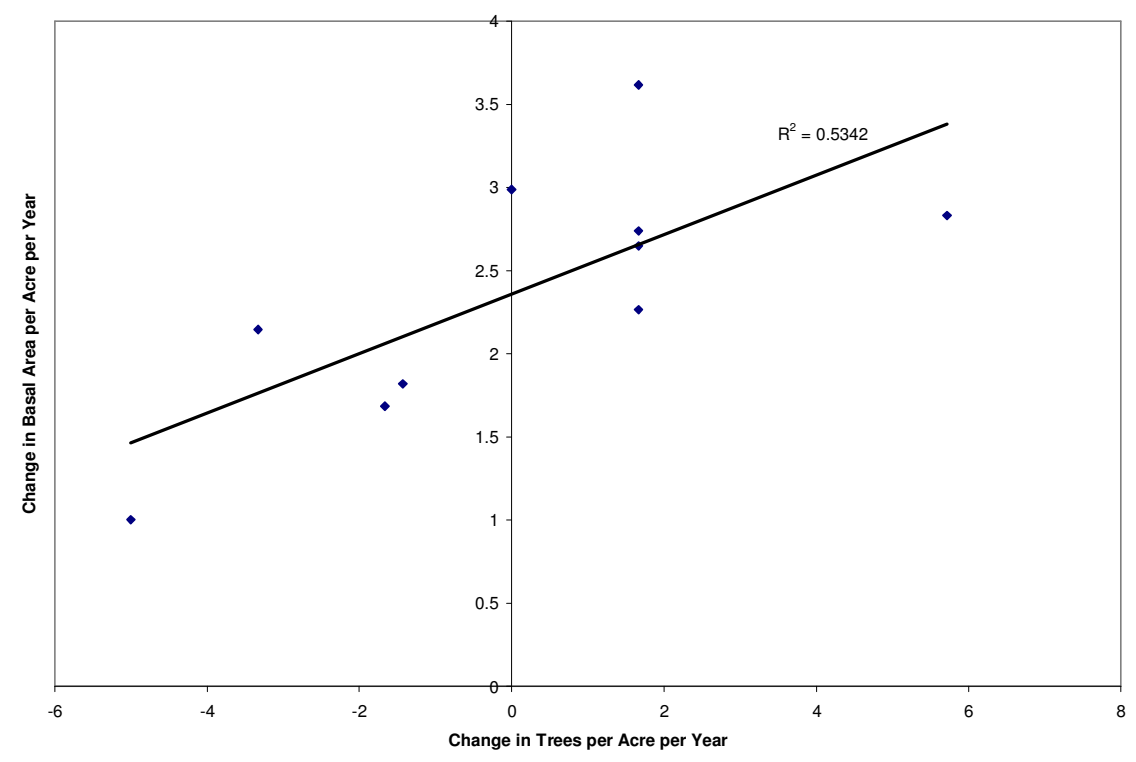

Figure A.4: Basal Area Growth per Year Plotted Against Average Age

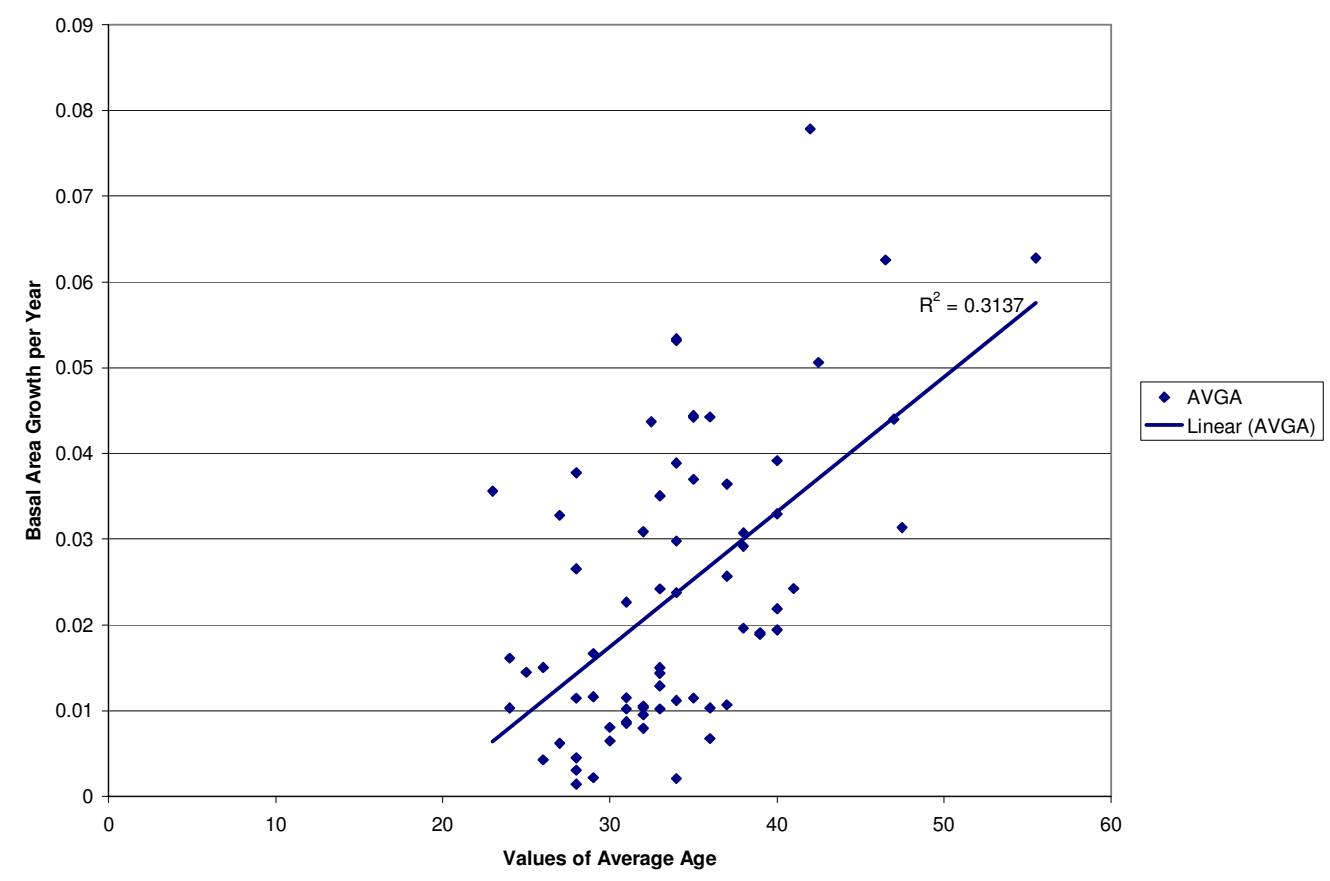


Figure A.5: Basal Area Growth per Year Plotted Against Average Total Height

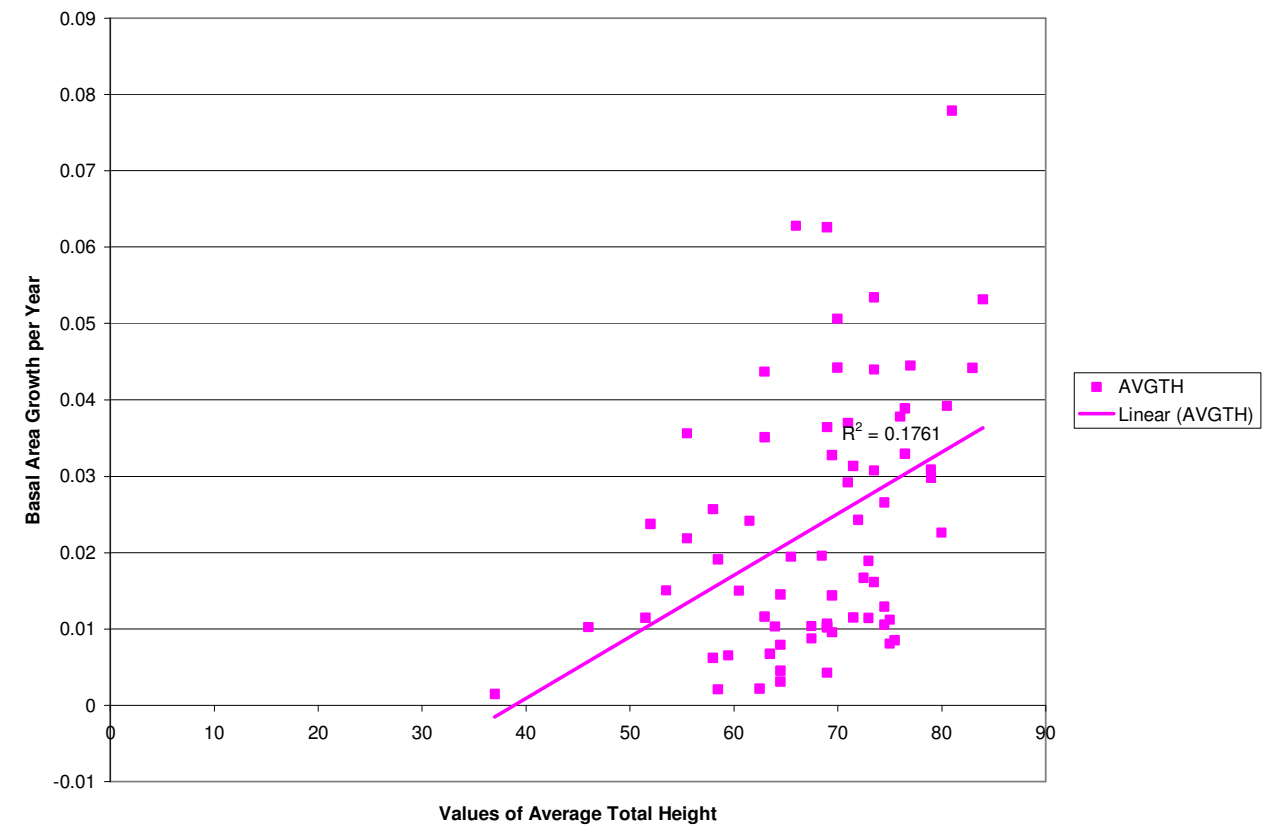

Figure A.6: Basal Area Growth per Year Plotted Against Average DBH

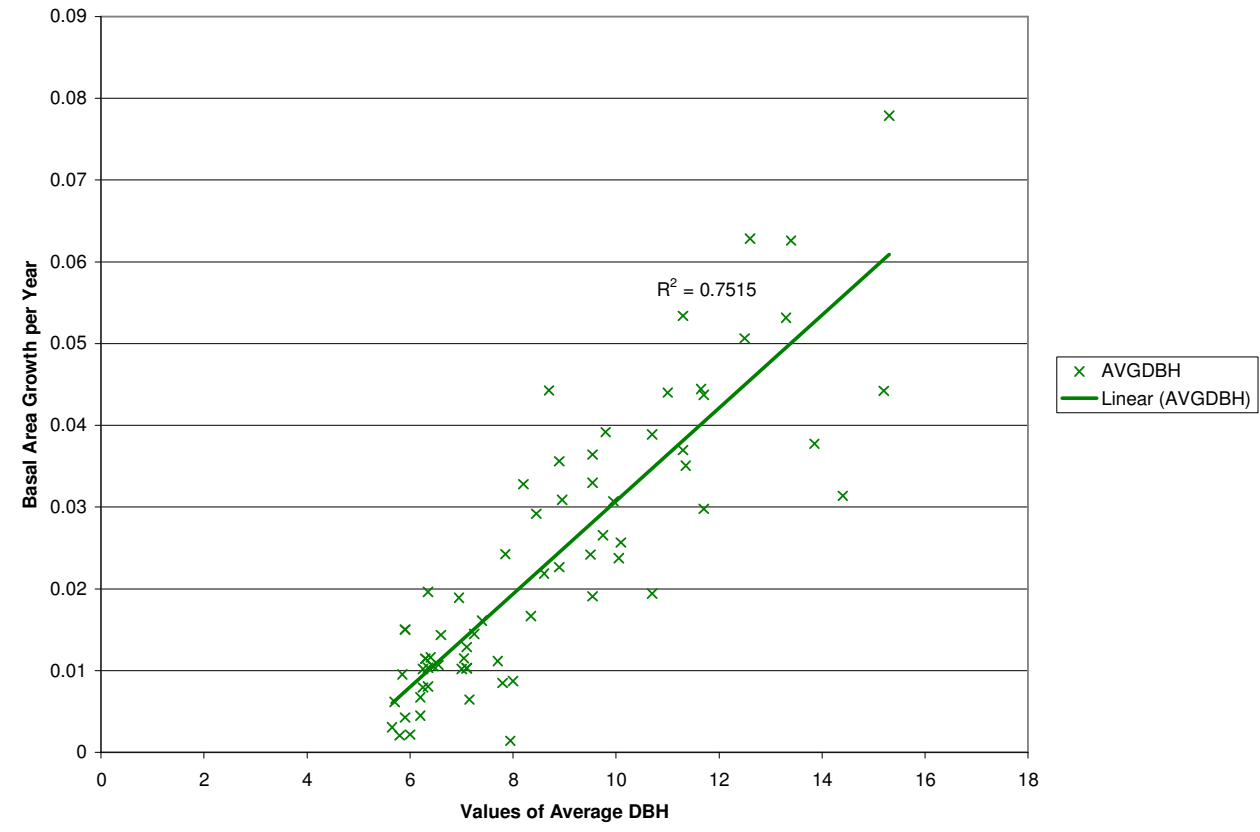


Figure A.7: Basal Area Growth per Year Plotted Against Average Crown Diameter

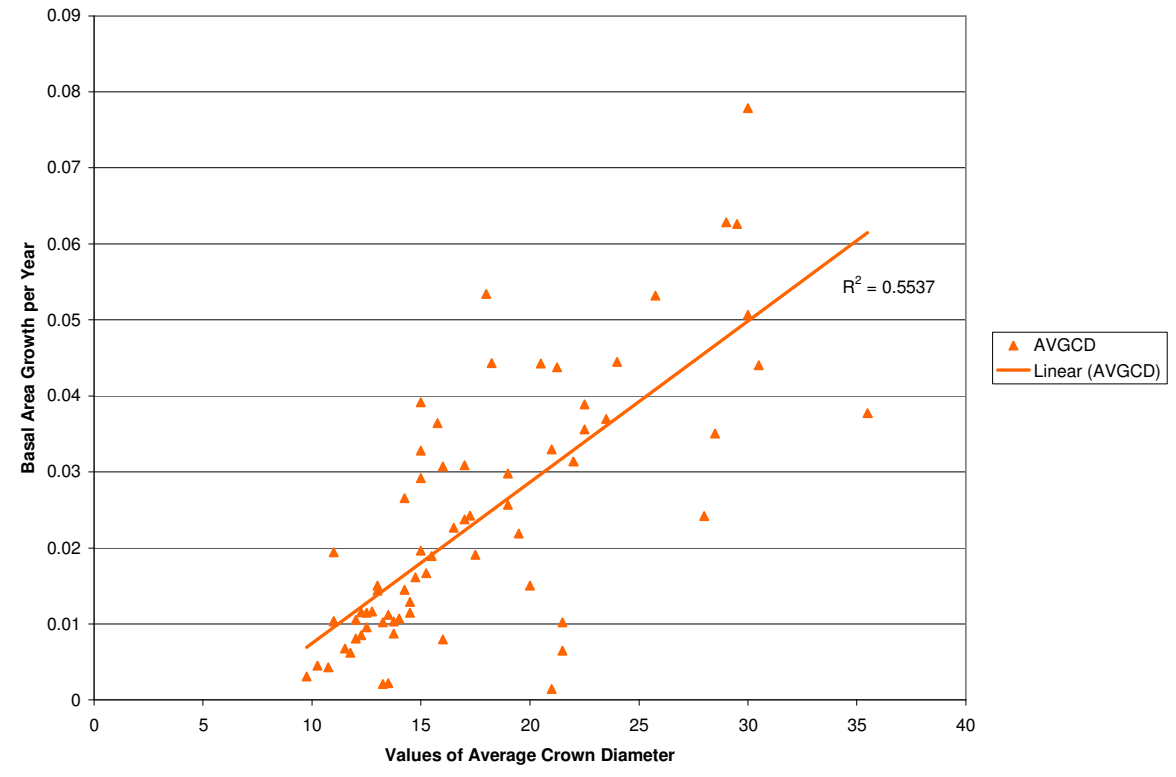

Figure A.8: Basal Area Growth per Year Plotted Against Change in Tree

\section{Characteristics per Year}

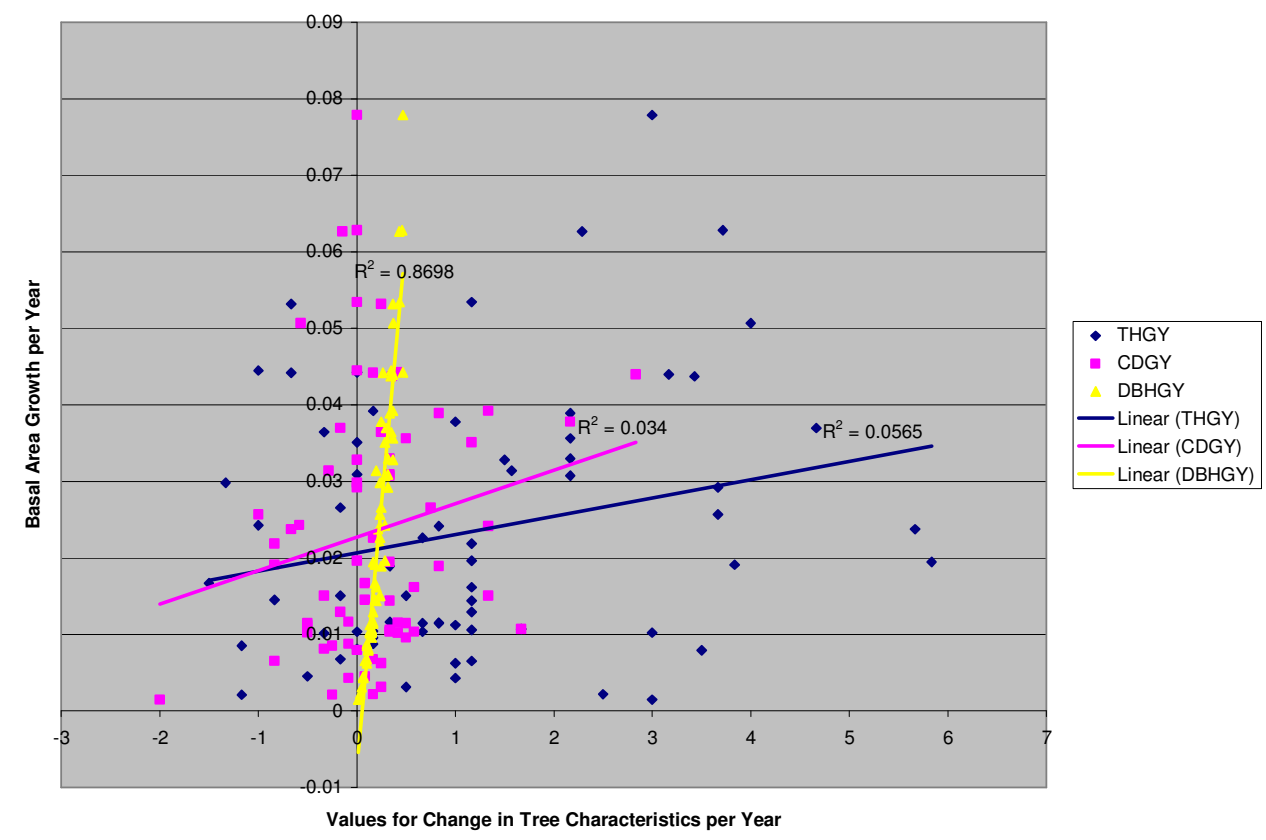


Figure A.9: Basal Area Growth per Year Plotted Against Initial Tree Characteristic

\section{Measurements}

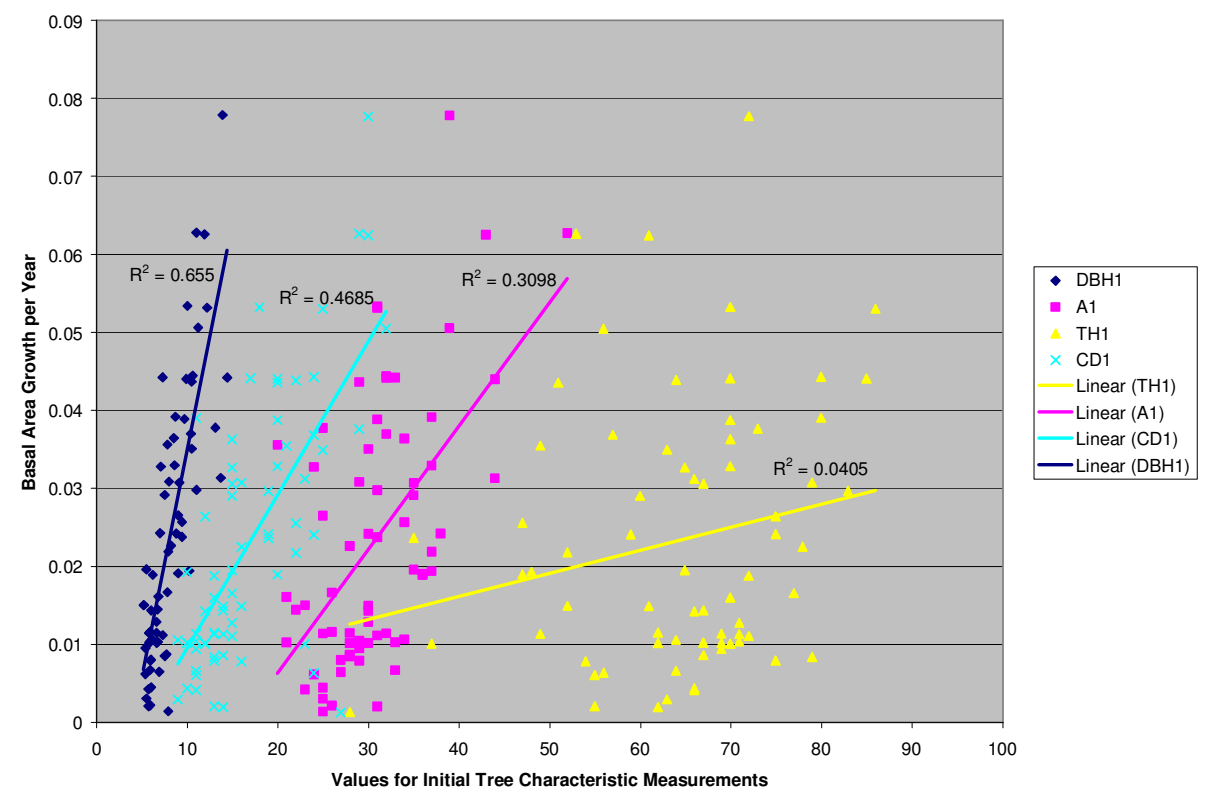

Figure A.10: Basal Area Growth per Year Plotted Against Final Tree Characteristic

\section{Measurements}

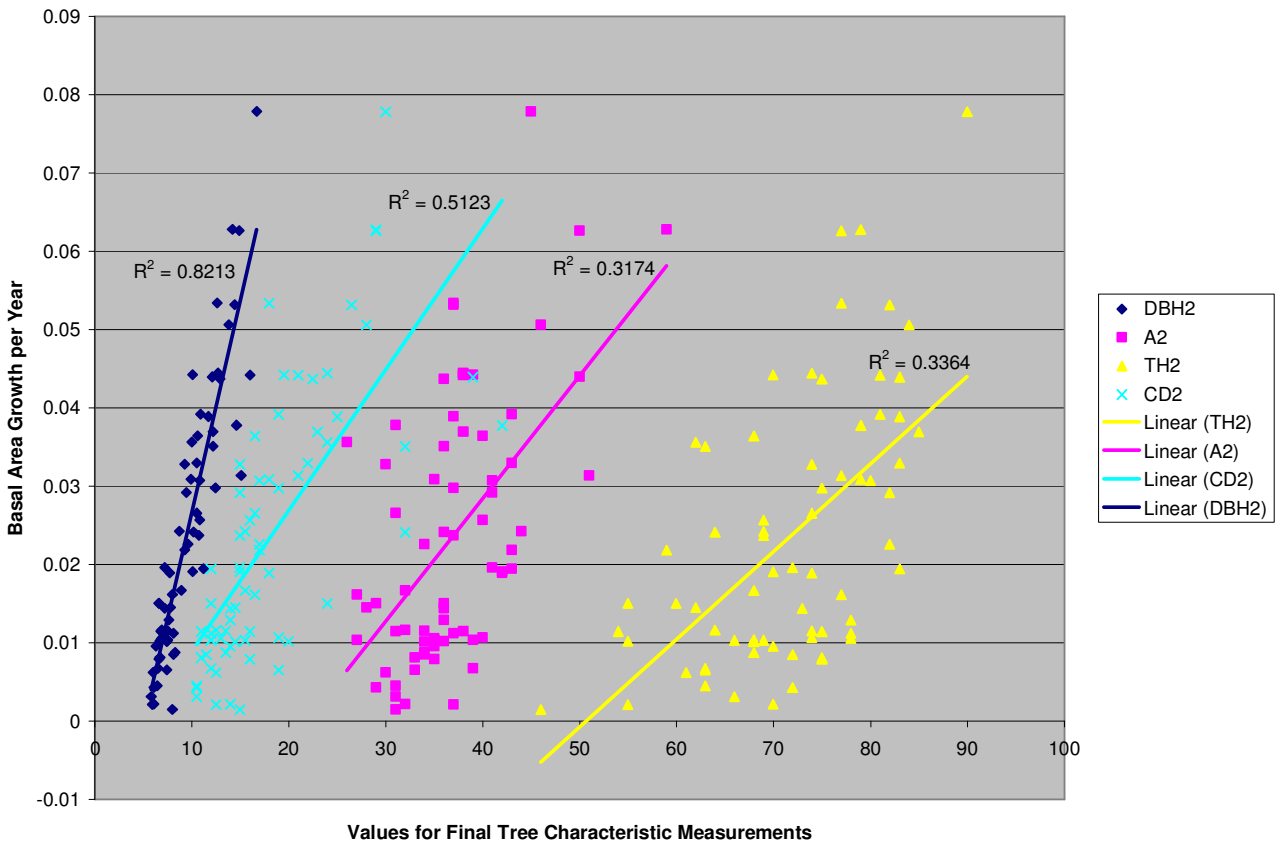


Figure A.11: Basal Area Growth per Year Plotted Against Residuals for Multiple Linear Regression Using the Averages of the Tree Characteristics

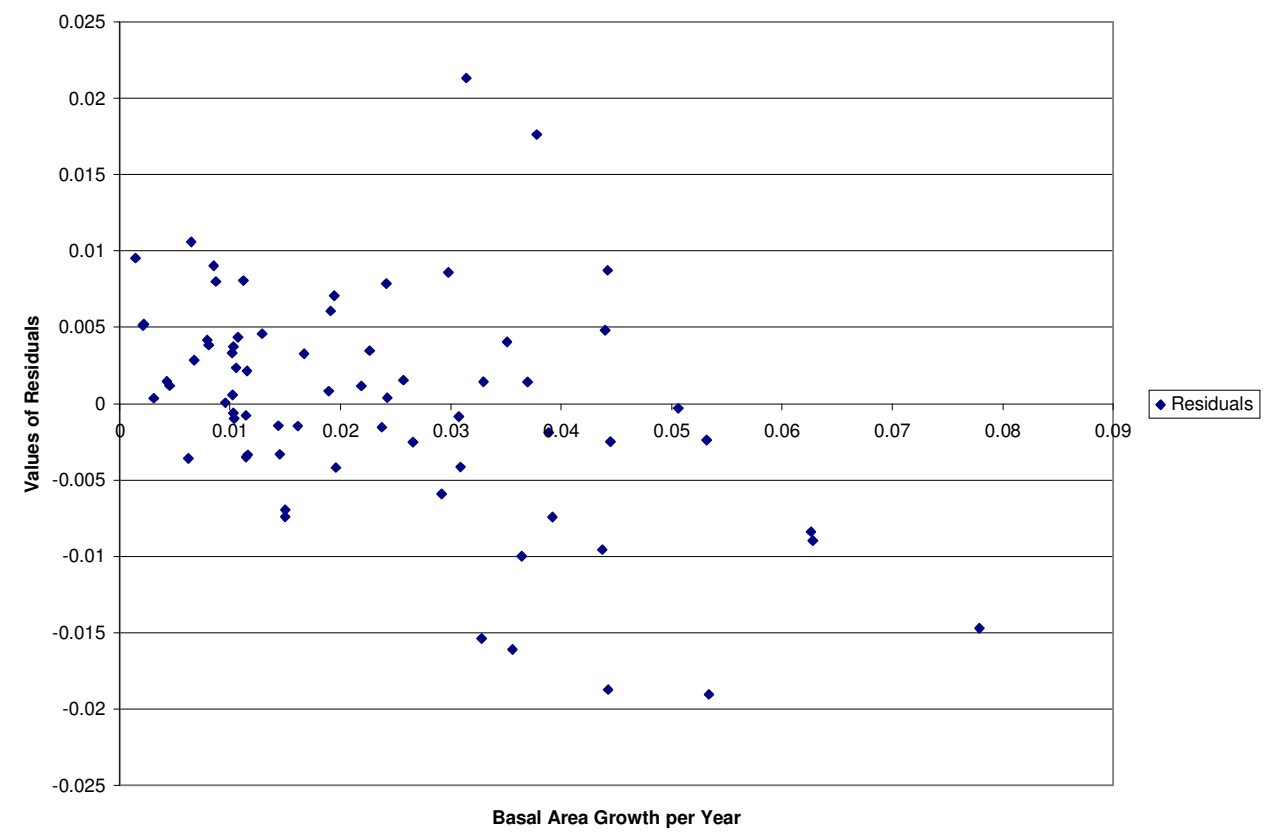

Figure A.12: Average DBH Plotted Against Residuals for Multiple Linear Regression Using the Averages of the Tree Characteristics

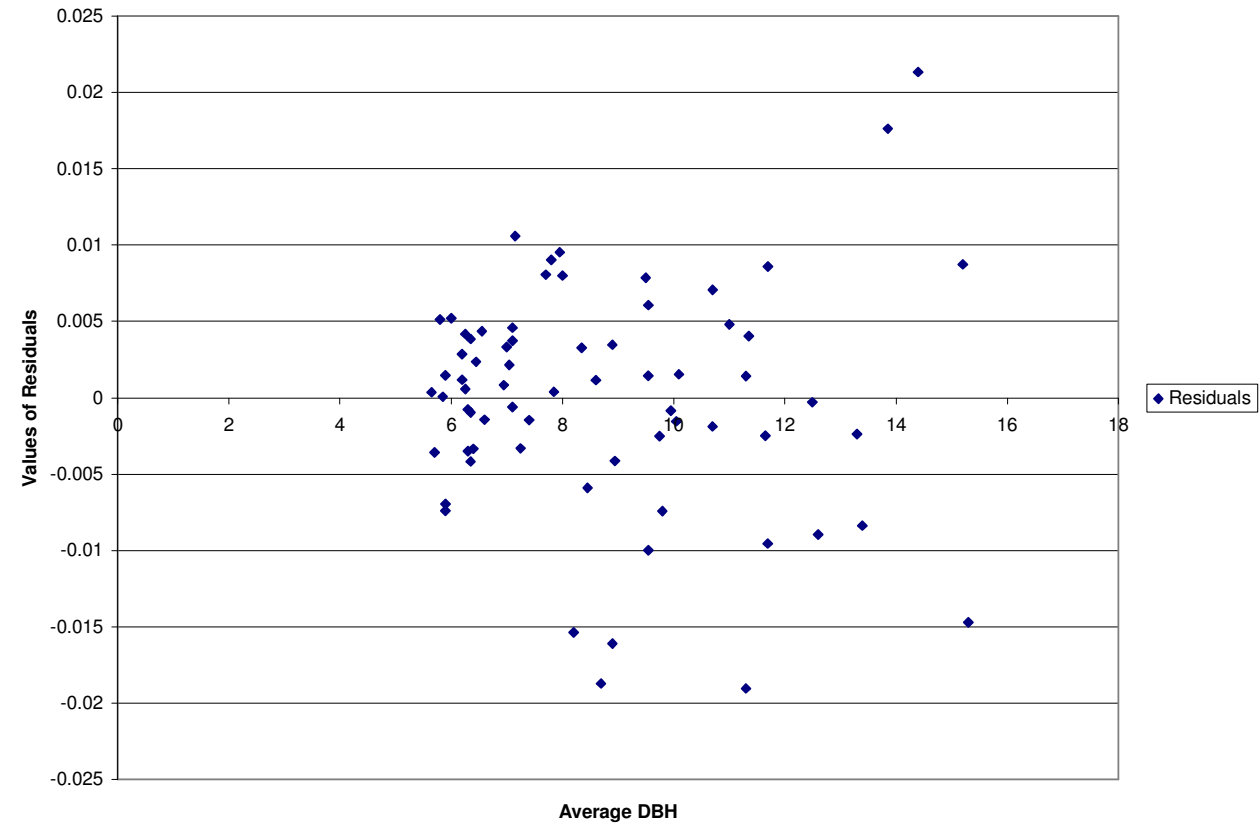


Figure A.13: Average Crown Diameter Plotted Against Residuals for Multiple Linear Regression Using the Averages of the Tree Characteristics

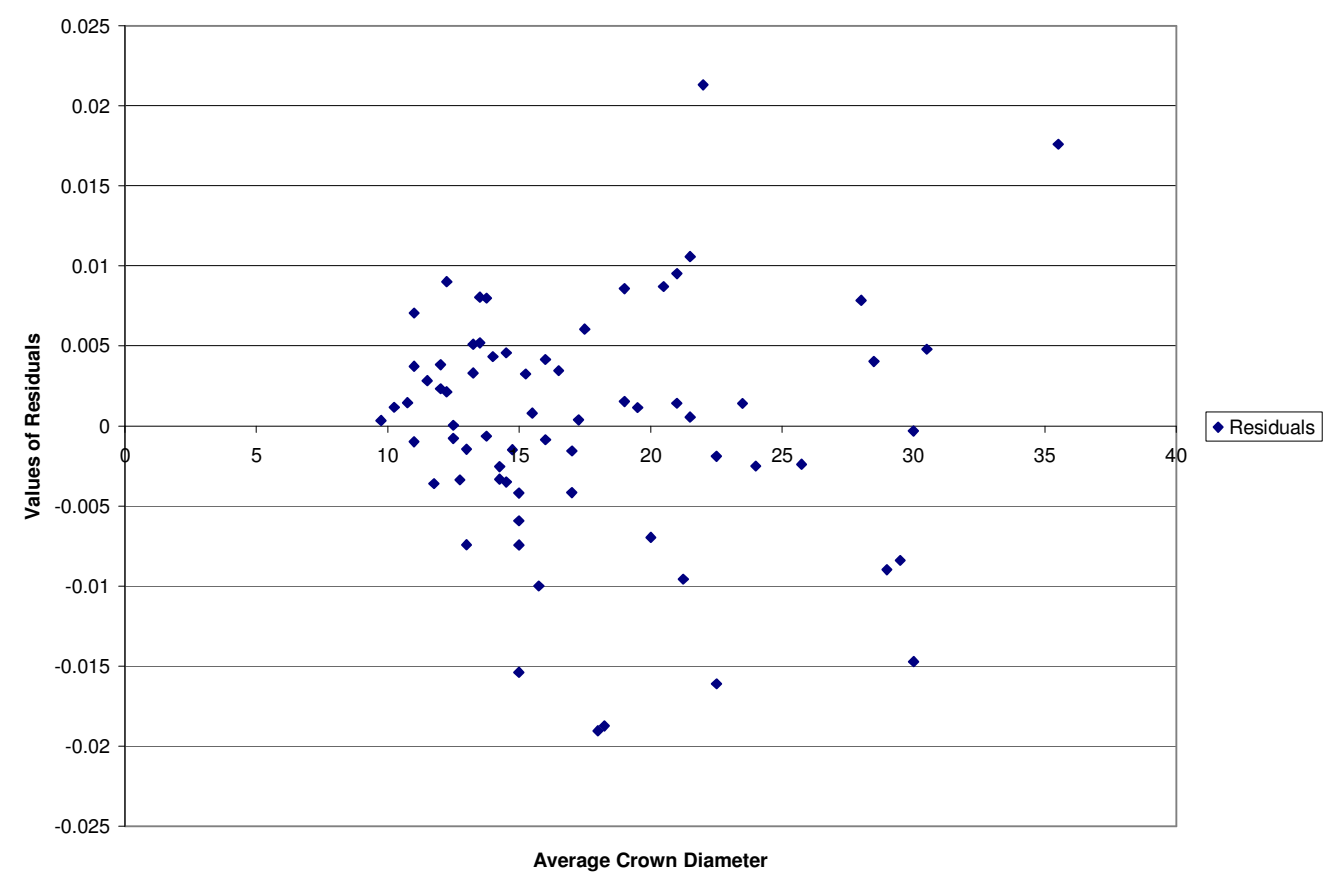

Figure A.14: Average Age Plotted Against Residuals for Multiple Linear Regression Using the Averages of the Tree Characteristics

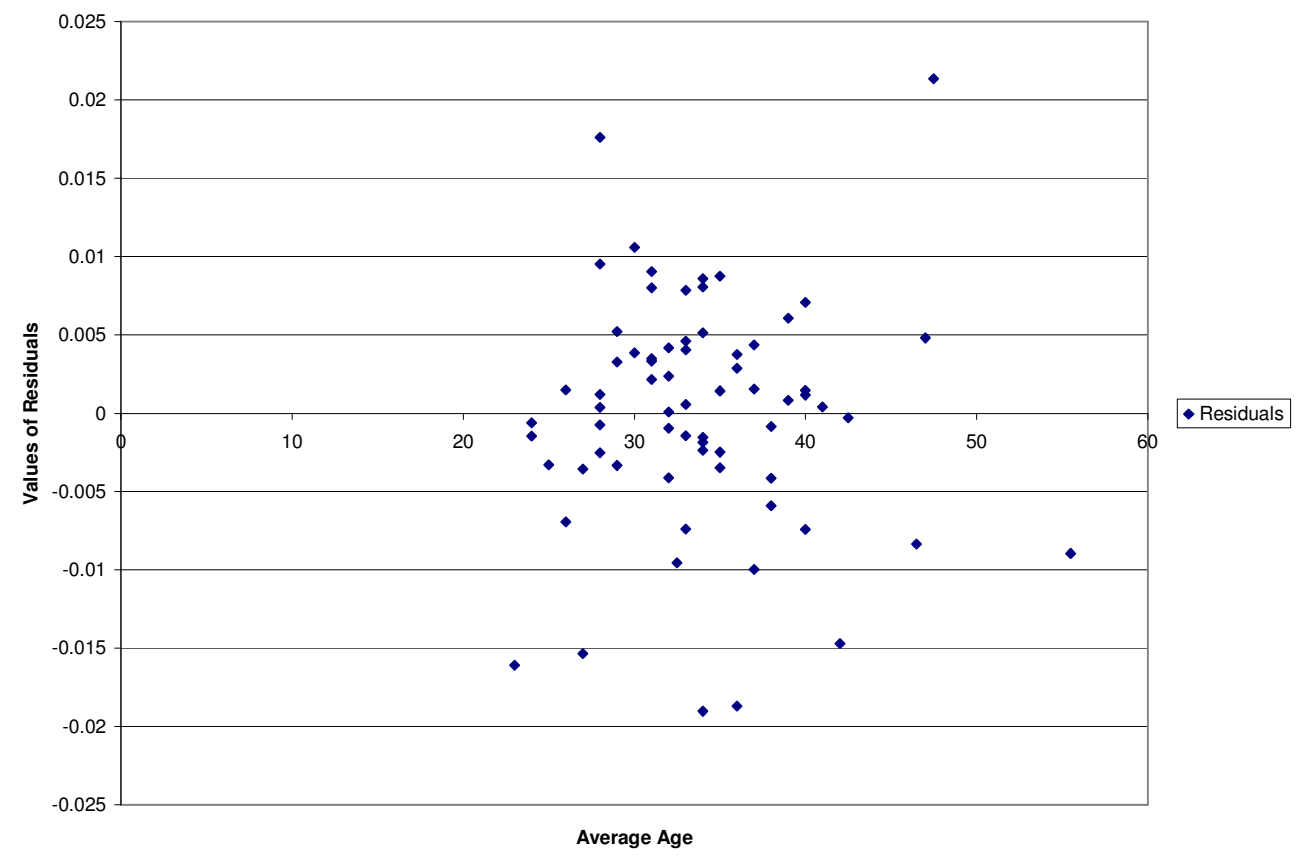


Figure A.15: Average Total Height Plotted Against Residuals for Multiple Linear Regression Using the Averages of the Tree Characteristics

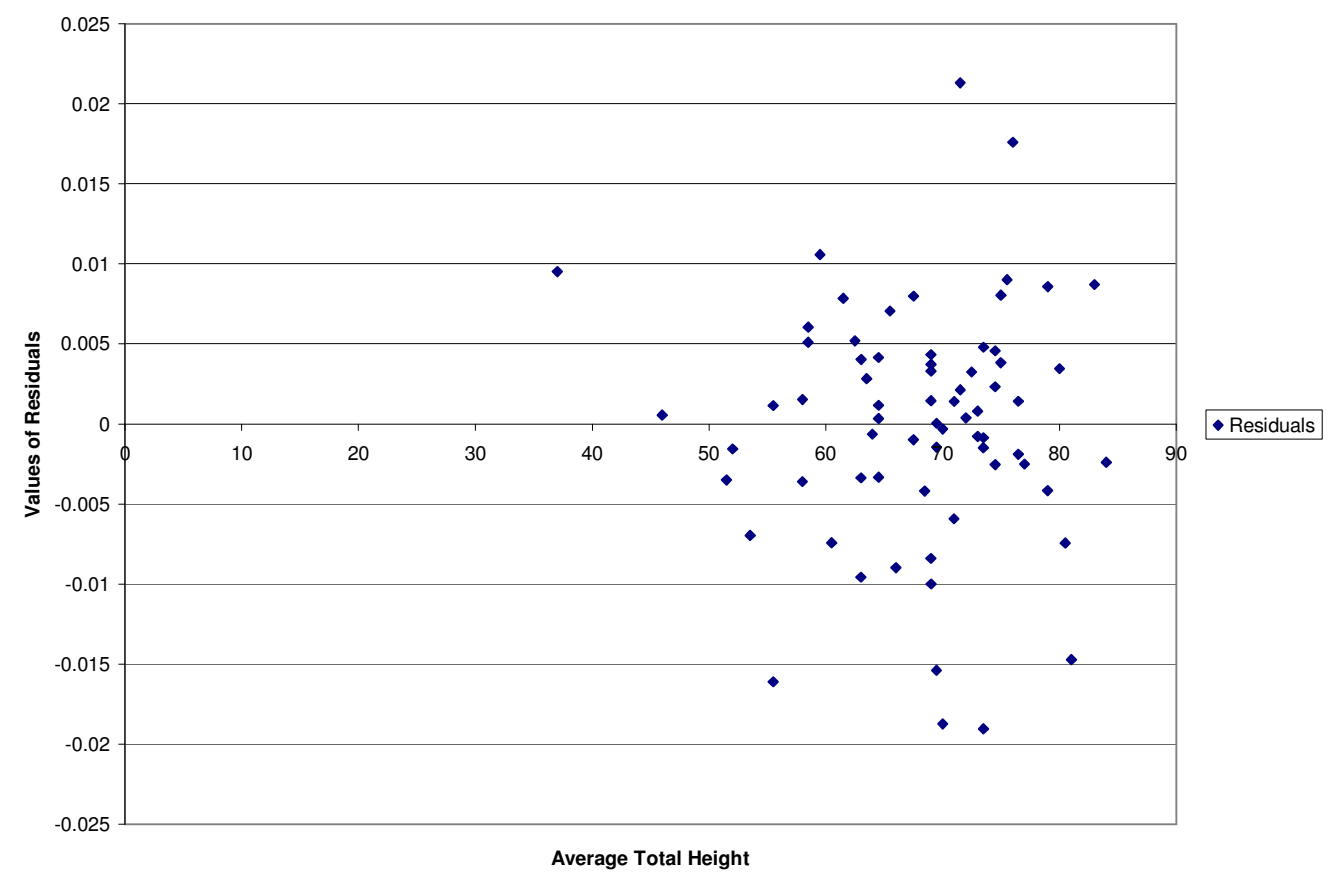


APPENDIX D

SAS OUTPUT 
Aspect

The SAS System

The REG Procedure

Mode 1: MODEL1

Dependent Variable: BAGY

$\begin{array}{ll}\text { Number of Observations Read } & 69 \\ \text { Number of Observations Used } & 69\end{array}$

Analysis of Variance

$\begin{array}{lrrrrr}\text { Source } & \text { DF } & \begin{array}{r}\text { Sum of } \\ \text { Squares }\end{array} & \begin{array}{r}\text { Mean } \\ \text { Square }\end{array} & \text { F value } & \text { Pr }>\text { F } \\ \text { Mode1 } & 1 & 0.00061581 & 0.00061581 & 2.19 & 0.1439 \\ \text { Error } & 67 & 0.01887 & 0.00028165 & & \\ \text { Corrected Total } & 68 & 0.01949 & & \\ & & & & \\ & & 0.01678 & \text { R-Square } & 0.0316 \\ & & 0.02348 & \text { Adj R-Sq } & 0.0171 \\ & \begin{array}{l}\text { Root MSE } \\ \text { Dependent Mean } \\ \text { Coeff Var }\end{array} & 71.48381 & & \end{array}$

Parameter Estimates

\begin{tabular}{|c|c|c|c|c|c|c|}
\hline Variable & Labe1 & DF & $\begin{array}{c}\text { Parameter } \\
\text { Estimate }\end{array}$ & $\begin{array}{r}\text { Standard } \\
\text { Error }\end{array}$ & t value & $\operatorname{Pr}>|t|$ \\
\hline $\begin{array}{l}\text { Intercept } \\
\text { ASP }\end{array}$ & $\begin{array}{l}\text { Intercept } \\
\text { ASP }\end{array}$ & $\begin{array}{l}1 \\
1\end{array}$ & $\begin{array}{r}0.03046 \\
-0.00472\end{array}$ & $\begin{array}{l}0.00514 \\
0.00319\end{array}$ & $\begin{array}{r}5.93 \\
-1.48\end{array}$ & $\begin{array}{l}<.0001 \\
0.1439\end{array}$ \\
\hline
\end{tabular}


Slope Position

The SAS System

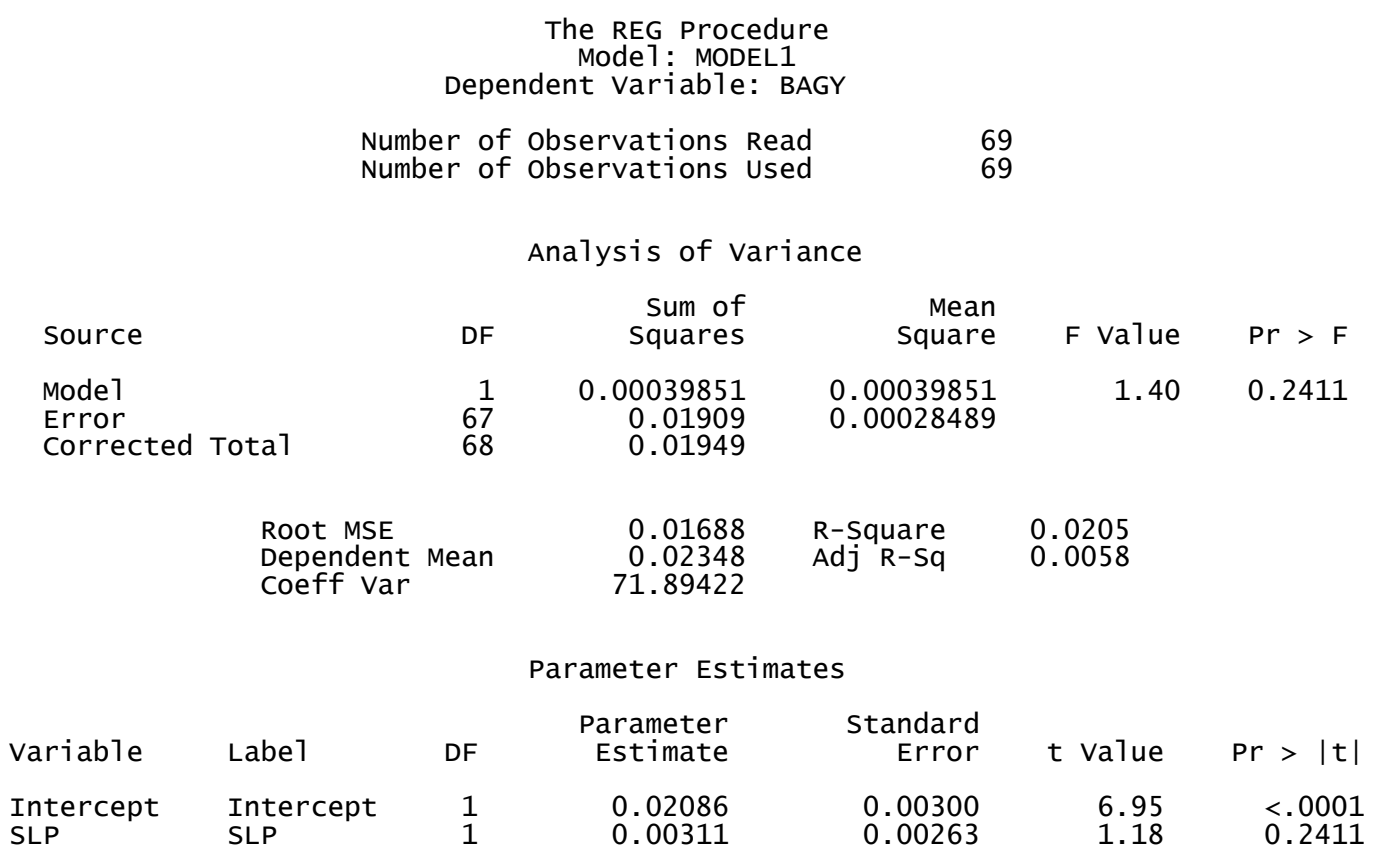


The REG Procedure

Mode 1: MODEL1

Dependent Variable: BAGY

$\begin{array}{ll}\text { Number of Observations Read } & 69 \\ \text { Number of Observations Used } & 69\end{array}$

Analysis of Variance

\begin{tabular}{|c|c|c|c|c|c|}
\hline Source & DF & $\begin{array}{r}\text { Sum of } \\
\text { squares }\end{array}$ & $\begin{array}{r}\text { Mean } \\
\text { square }\end{array}$ & F value & $\mathrm{Pr}>\mathrm{F}$ \\
\hline $\begin{array}{l}\text { Mode1 } \\
\text { Error } \\
\text { Corrected Total }\end{array}$ & $\begin{array}{l}1 \\
67 \\
68\end{array}$ & $\begin{array}{r}0.00000290 \\
0.01948 \\
0.01949\end{array}$ & $\begin{array}{l}0.00000290 \\
0.00029080\end{array}$ & 0.01 & 0.9207 \\
\hline
\end{tabular}

Root MSE
Dependent Mean
Coeff Var

$$
\begin{array}{r}
0.01705 \\
0.02348 \\
72.63543
\end{array}
$$

R-Square

Adj R-Sq

0.0001

$-0.0148$

Parameter Estimates

$\begin{array}{ll}\text { Variable } & \text { Labe1 } \\ \text { Intercept } & \text { Intercept } \\ \text { STP } & \text { STP }\end{array}$

DF
1
1

Standard
Error

0.00340

0.00340 t value

6.99

$-0.10$
$\operatorname{Pr}>|t|$
$<.0001$
0.9207 
Landform

The SAS System

The REG Procedure

Mode 1: MODEL1

Dependent Variable: BAGY

$\begin{array}{ll}\text { Number of Observations Read } & 69 \\ \text { Number of Observations Used } & 69\end{array}$

Analysis of Variance

\begin{tabular}{|c|c|c|c|c|c|}
\hline Source & DF & $\begin{array}{r}\text { Sum of } \\
\text { squares }\end{array}$ & $\begin{array}{r}\text { Mean } \\
\text { square }\end{array}$ & F value & $\mathrm{Pr}>\mathrm{F}$ \\
\hline $\begin{array}{l}\text { Mode1 } \\
\text { Error } \\
\text { Corrected Total }\end{array}$ & $\begin{array}{l}1 \\
67 \\
68\end{array}$ & $\begin{array}{r}0.00002433 \\
0.01946 \\
0.01949\end{array}$ & $\begin{array}{l}0.00002433 \\
0.00029048\end{array}$ & 0.08 & 0.7732 \\
\hline
\end{tabular}

Root MSE
Dependent Mean
Coeff Var

$\begin{array}{rrr}0.01704 & \text { R-Square } & 0.0012 \\ 0.02348 & \text { Adj R-Sq } & -0.0137 \\ 72.59547 & \end{array}$

Parameter Estimates

$\begin{array}{llrrrrr}\text { Variable } & \text { Label } & \text { DF } & \begin{array}{r}\text { Parameter } \\ \text { Estimate }\end{array} & \begin{array}{r}\text { Standard } \\ \text { Error }\end{array} & t \text { value } & \operatorname{Pr}>|t| \\ \text { Intercept } & \text { Intercept } & 1 & 0.02184 & 0.00601 & 3.63 & 0.0005 \\ \text { LF } & \text { LF } & 1 & 0.00136 & 0.00470 & 0.29 & 0.7732\end{array}$


Total site

The SAS System

The REG Procedure

Mode 1: MODEL1

Dependent Variable: BAGY

$\begin{array}{ll}\text { Number of Observations Read } & 69 \\ \text { Number of Observations Used } & 69\end{array}$

\begin{tabular}{|c|c|c|c|c|c|c|}
\hline \multicolumn{7}{|c|}{ Analysis of Variance } \\
\hline Source & & DF & $\begin{array}{l}\text { Sum of } \\
\text { squares }\end{array}$ & $\begin{array}{r}\text { Mean } \\
\text { Square }\end{array}$ & F value & $\mathrm{Pr}>\mathrm{F}$ \\
\hline $\begin{array}{l}\text { Mode1 } \\
\text { Error } \\
\text { Corrected }\end{array}$ & Tota1 & $\begin{array}{l}1 \\
67 \\
68\end{array}$ & $\begin{array}{r}4.700804 \mathrm{E}-7 \\
0.01949 \\
0.01949\end{array}$ & $\begin{array}{r}4.700804 \mathrm{E}-7 \\
0.00029083\end{array}$ & 0.00 & 0.9681 \\
\hline & $\begin{array}{l}\text { Root MSE } \\
\text { Dependent } \\
\text { Coeff Var }\end{array}$ & Mean & $\begin{array}{r}0.01705 \\
0.02348 \\
72.63996\end{array}$ & $\begin{array}{l}\text { R-Square } \\
\text { Adj R-Sq }\end{array}$ & $\begin{array}{r}0.0000 \\
-0.0149\end{array}$ & \\
\hline \multicolumn{7}{|c|}{ Parameter Estimates } \\
\hline Variable & Labe1 & DF & $\begin{array}{c}\text { Parameter } \\
\text { Estimate }\end{array}$ & $\begin{array}{r}\text { Standard } \\
\text { Error }\end{array}$ & t value & $\operatorname{Pr}>|t|$ \\
\hline $\begin{array}{l}\text { Intercept } \\
\text { TS }\end{array}$ & $\begin{array}{l}\text { Intercept } \\
\text { TS }\end{array}$ & $\begin{array}{l}1 \\
1\end{array}$ & $\begin{array}{r}0.02319 \\
0.00006721\end{array}$ & $\begin{array}{l}0.00751 \\
0.00167\end{array}$ & $\begin{array}{l}3.09 \\
0.04\end{array}$ & $\begin{array}{l}0.0029 \\
0.9681\end{array}$ \\
\hline
\end{tabular}


Change in Basal Area per Acre per Year The SAS System

The REG Procedure

Mode 1: MODEL1

Dependent Variable: BAGY

$\begin{array}{ll}\text { Number of Observations Read } & 69 \\ \text { Number of Observations Used } & 69\end{array}$

\begin{tabular}{|c|c|c|c|c|c|c|}
\hline \multicolumn{7}{|c|}{ Analysis of Variance } \\
\hline Source & & DF & $\begin{array}{l}\text { Sum of } \\
\text { Squares }\end{array}$ & $\begin{array}{r}\text { Mean } \\
\text { Square }\end{array}$ & F value & $\mathrm{Pr}>\mathrm{F}$ \\
\hline $\begin{array}{l}\text { Mode1 } \\
\text { Error } \\
\text { Corrected }\end{array}$ & Tota1 & $\begin{array}{l}1 \\
67 \\
68\end{array}$ & $\begin{array}{r}0.00023100 \\
0.01926 \\
0.01949\end{array}$ & $\begin{array}{l}0.00023100 \\
0.00028739\end{array}$ & 0.80 & 0.3732 \\
\hline & $\begin{array}{l}\text { Root MSE } \\
\text { Dependent } \\
\text { Coeff Var }\end{array}$ & Mean & $\begin{array}{r}0.01695 \\
0.02348 \\
72.20900\end{array}$ & $\begin{array}{l}\text { R-Square } \\
\text { Adj R-Sq }\end{array}$ & $\begin{array}{r}0.0119 \\
-0.0029\end{array}$ & \\
\hline \multicolumn{7}{|c|}{ Parameter Estimates } \\
\hline Variable & Labe1 & DF & $\begin{array}{c}\text { Parameter } \\
\text { Estimate }\end{array}$ & $\begin{array}{r}\text { Standard } \\
\text { Error }\end{array}$ & t value & $\operatorname{Pr}>|t|$ \\
\hline $\begin{array}{l}\text { Intercept } \\
\text { BAAGY }\end{array}$ & $\begin{array}{l}\text { Intercept } \\
\text { BAAGY }\end{array}$ & $\begin{array}{l}1 \\
1\end{array}$ & $\begin{array}{r}0.02882 \\
-0.00216\end{array}$ & $\begin{array}{l}0.00630 \\
0.00241\end{array}$ & $\begin{array}{r}4.57 \\
-0.90\end{array}$ & $\begin{array}{l}<.0001 \\
0.3732\end{array}$ \\
\hline
\end{tabular}


Change in Trees per Acre per Year The SAS System

The REG Procedure

Mode 1: MODEL1

Dependent Variable: BAGY

$\begin{array}{ll}\text { Number of Observations Read } & 69 \\ \text { Number of Observations Used } & 69\end{array}$

Analysis of Variance

\begin{tabular}{|c|c|c|c|c|c|}
\hline Source & DF & $\begin{array}{l}\text { Sum of } \\
\text { Squares }\end{array}$ & $\begin{array}{r}\text { Mean } \\
\text { Square }\end{array}$ & F value & $\mathrm{Pr}>\mathrm{F}$ \\
\hline $\begin{array}{l}\text { Mode1 } \\
\text { Error } \\
\text { Corrected Tota1 }\end{array}$ & $\begin{array}{l}1 \\
67 \\
68\end{array}$ & $\begin{array}{r}0.00030274 \\
0.01918 \\
0.01949\end{array}$ & $\begin{array}{l}0.00030274 \\
0.00028632\end{array}$ & 1.06 & 0.3075 \\
\hline & Mean & $\begin{array}{r}0.01692 \\
0.02348 \\
72.07435\end{array}$ & $\begin{array}{l}\text { R-Square } \\
\text { Adj R-Sq }\end{array}$ & $\begin{array}{l}0.0155 \\
0.0008\end{array}$ & \\
\hline
\end{tabular}

Parameter Estimates

$\begin{array}{llrrrrr}\text { Variable } & \text { Labe1 } & \text { DF } & \begin{array}{r}\text { Parameter } \\ \text { Estimate }\end{array} & \begin{array}{r}\text { Standard } \\ \text { Error }\end{array} & t \text { value } & \operatorname{Pr}>|t| \\ \text { Intercept } & \text { Intercept } & 1 & 0.02314 & 0.00206 & 11.21 & <.0001 \\ \text { TPAGY } & \text { TPAGY } & 1 & -0.00081006 & 0.00078779 & -1.03 & 0.3075\end{array}$


Change in Basal Area per Acre per Year versus Change in Trees per Acre per Year The SAS System

The REG Procedure

Mode 1: MODEL1

Dependent Variable: BAAGY

$\begin{array}{ll}\text { Number of observations Read } & 10 \\ \text { Number of Observations Used } & 10\end{array}$

\begin{tabular}{|c|c|c|c|c|c|c|}
\hline \multicolumn{7}{|c|}{ Analysis of variance } \\
\hline Source & & DF & $\begin{array}{l}\text { Sum of } \\
\text { Squares }\end{array}$ & $\begin{array}{r}\text { Mean } \\
\text { Square }\end{array}$ & F value & $\mathrm{Pr}>\mathrm{F}$ \\
\hline $\begin{array}{l}\text { Mode1 } \\
\text { Error } \\
\text { Corrected }\end{array}$ & Tota1 & $\begin{array}{l}1 \\
8 \\
9\end{array}$ & $\begin{array}{l}2.70751 \\
2.36066 \\
5.06816\end{array}$ & $\begin{array}{l}2.70751 \\
0.29508\end{array}$ & 9.18 & 0.0163 \\
\hline & $\begin{array}{l}\text { Root MSE } \\
\text { Dependent } \\
\text { Coeff Var }\end{array}$ & Mean & $\begin{array}{r}0.54321 \\
2.37453 \\
22.87677\end{array}$ & $\begin{array}{l}\text { R-Square } \\
\text { Adj R-Sq }\end{array}$ & $\begin{array}{l}0.5342 \\
0.4760\end{array}$ & \\
\hline \multicolumn{7}{|c|}{ Parameter Estimates } \\
\hline variable & Labe1 & DF & $\begin{array}{c}\text { Parameter } \\
\text { Estimate }\end{array}$ & $\begin{array}{r}\text { Standard } \\
\text { Error }\end{array}$ & t value & $\operatorname{Pr}>|t|$ \\
\hline $\begin{array}{l}\text { Intercept } \\
\text { TPAGY }\end{array}$ & $\begin{array}{l}\text { Intercept } \\
\text { TPAGY }\end{array}$ & $\begin{array}{l}1 \\
1\end{array}$ & $\begin{array}{l}2.35749 \\
0.17889\end{array}$ & $\begin{array}{l}0.17187 \\
0.05906\end{array}$ & $\begin{array}{r}13.72 \\
3.03\end{array}$ & $\begin{array}{l}<.0001 \\
0.0163\end{array}$ \\
\hline
\end{tabular}


Average Basal Area per Acre

The SAS system

The REG Procedure

Mode 1: MODEL1

Dependent Variable: BAGY

Number of observations Read $\quad 69$

Number of Observations Used 69

\begin{tabular}{|c|c|c|c|c|c|c|}
\hline \multicolumn{7}{|c|}{ Analysis of Variance } \\
\hline Source & & DF & $\begin{array}{l}\text { Sum of } \\
\text { squares }\end{array}$ & $\begin{array}{r}\text { Mean } \\
\text { Square }\end{array}$ & F value & $\mathrm{Pr}>\mathrm{F}$ \\
\hline $\begin{array}{l}\text { Mode1 } \\
\text { Error } \\
\text { Corrected }\end{array}$ & Total & $\begin{array}{l}1 \\
67 \\
68\end{array}$ & $\begin{array}{r}0.00007202 \\
0.01941 \\
0.01949\end{array}$ & $\begin{array}{l}0.00007202 \\
0.00028976\end{array}$ & 0.25 & 0.6197 \\
\hline & $\begin{array}{l}\text { Root MSE } \\
\text { Dependent } \\
\text { Coeff Var }\end{array}$ & Mean & $\begin{array}{r}0.01702 \\
0.02348 \\
72.50647\end{array}$ & $\begin{array}{l}\text { R-Square } \\
\text { Adj R-Sq }\end{array}$ & $\begin{array}{r}0.0037 \\
-0.0112\end{array}$ & \\
\hline \multicolumn{7}{|c|}{ Parameter Estimates } \\
\hline Variable & Labe1 & DF & $\begin{array}{l}\text { Parameter } \\
\text { Estimate }\end{array}$ & $\begin{array}{r}\text { Standard } \\
\text { Error }\end{array}$ & t value & $\operatorname{Pr}>|t|$ \\
\hline $\begin{array}{l}\text { Intercept } \\
\text { AVGBAA }\end{array}$ & $\begin{array}{l}\text { Intercept } \\
\text { AVGBAA }\end{array}$ & $\begin{array}{l}1 \\
1\end{array}$ & $\begin{array}{r}0.01616 \\
0.00009426\end{array}$ & $\begin{array}{r}0.01482 \\
0.00018907\end{array}$ & $\begin{array}{l}1.09 \\
0.50\end{array}$ & $\begin{array}{l}0.2796 \\
0.6197\end{array}$ \\
\hline
\end{tabular}


Average Trees per Acre

The SAS System

The REG Procedure

Mode 1: MODEL1

Dependent Variable: BAGY

$\begin{array}{ll}\text { Number of Observations Read } & 69 \\ \text { Number of Observations Used } & 69\end{array}$

Analysis of Variance

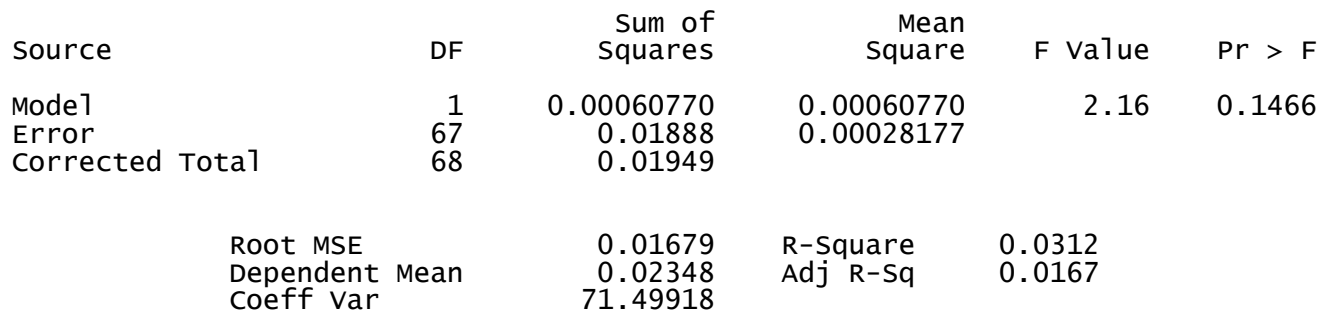

Parameter Estimates

$\begin{array}{llrrrrr}\text { Variable } & \text { Labe1 } & \text { DF } & \begin{array}{r}\text { Parameter } \\ \text { Estimate }\end{array} & \begin{array}{r}\text { Standard } \\ \text { Error }\end{array} & t \text { value } & \text { Pr }>|t| \\ \text { Intercept } & \text { Intercept } & 1 & 0.04173 & 0.01259 & 3.31 & 0.0015 \\ \text { AVGTPA } & \text { AVGTPA } & 1 & -0.00009210 & 0.00006271 & -1.47 & 0.1466\end{array}$


Average Age

The SAS System

The REG Procedure

Mode 1: MODEL1

Dependent Variable: BAGY

$\begin{array}{ll}\text { Number of Observations Read } & 69 \\ \text { Number of Observations Used } & 69\end{array}$

Analysis of Variance

$\begin{array}{lrrrrr}\text { Source } & \text { DF } & \begin{array}{r}\text { Sum of } \\ \text { Squares }\end{array} & \begin{array}{r}\text { Mean } \\ \text { Square }\end{array} & \text { F Value } & \text { Pr }>\text { F } \\ \text { Mode1 } & 1 & 0.00611 & 0.00611 & 30.63 & <.0001 \\ \text { Error } & 67 & 0.01337 & 0.00019959 & & \\ \text { Corrected Total } & 68 & 0.01949 & & \\ & & & & \\ & & 0.01413 & \text { R-Square } & 0.3137 \\ & \begin{array}{l}\text { Root MSE } \\ \text { Dependent Mean } \\ \text { Coeff Var }\end{array} & 0.02348 & \text { Adj R-Sq } & 0.3035 & \end{array}$

Parameter Estimates

\begin{tabular}{|c|c|c|c|c|c|c|}
\hline Variable & Labe1 & DF & $\begin{array}{r}\text { Parameter } \\
\text { Estimate }\end{array}$ & $\begin{array}{r}\text { Standard } \\
\text { Error }\end{array}$ & t value & $\operatorname{Pr}>|t|$ \\
\hline $\begin{array}{l}\text { Intercept } \\
\text { AVGA }\end{array}$ & $\begin{array}{l}\text { Intercept } \\
\text { AVGA }\end{array}$ & $\begin{array}{l}1 \\
1\end{array}$ & $\begin{array}{r}-0.02982 \\
0.00158\end{array}$ & $\begin{array}{r}0.00978 \\
0.00028473\end{array}$ & $\begin{array}{r}-3.05 \\
5.53\end{array}$ & $\begin{array}{l}0.0033 \\
<.0001\end{array}$ \\
\hline
\end{tabular}


Average Total Height

The SAS System

The REG Procedure

Mode 1: MODEL1

Dependent Variable: BAGY

Number of Observations Read $\quad 69$

Number of Observations Used 69

\begin{tabular}{|c|c|c|c|c|c|c|}
\hline \multicolumn{7}{|c|}{ Analysis of Variance } \\
\hline Source & & DF & $\begin{array}{l}\text { Sum of } \\
\text { squares }\end{array}$ & $\begin{array}{r}\text { Mean } \\
\text { Square }\end{array}$ & F value & $\mathrm{Pr}>\mathrm{F}$ \\
\hline $\begin{array}{l}\text { Mode1 } \\
\text { Error } \\
\text { Corrected }\end{array}$ & Total & $\begin{array}{l}1 \\
67 \\
68\end{array}$ & $\begin{array}{l}0.00343 \\
0.01605 \\
0.01949\end{array}$ & $\begin{array}{r}0.00343 \\
0.00023962\end{array}$ & 14.32 & 0.0003 \\
\hline & $\begin{array}{l}\text { Root MSE } \\
\text { Dependent } \\
\text { Coeff Var }\end{array}$ & Mean & $\begin{array}{r}0.01548 \\
0.02348 \\
65.93478\end{array}$ & $\begin{array}{l}\text { R-Square } \\
\text { Adj R-Sq }\end{array}$ & $\begin{array}{l}0.1761 \\
0.1638\end{array}$ & \\
\hline \multicolumn{7}{|c|}{ Parameter Estimates } \\
\hline Variable & Labe1 & DF & $\begin{array}{c}\text { Parameter } \\
\text { Estimate }\end{array}$ & $\begin{array}{r}\text { Standard } \\
\text { Error }\end{array}$ & t value & $\operatorname{Pr}>|t|$ \\
\hline $\begin{array}{l}\text { Intercept } \\
\text { AVGTH }\end{array}$ & $\begin{array}{l}\text { Intercept } \\
\text { AVGTH }\end{array}$ & $\begin{array}{l}1 \\
1\end{array}$ & $\begin{array}{r}-0.03132 \\
0.00080605\end{array}$ & $\begin{array}{r}0.01460 \\
0.00021299\end{array}$ & $\begin{array}{r}-2.15 \\
3.78\end{array}$ & $\begin{array}{l}0.0355 \\
0.0003\end{array}$ \\
\hline
\end{tabular}


Average Crown Diameter

The SAS System

\begin{tabular}{|c|c|c|c|c|c|c|c|}
\hline & & & Depen & $\begin{array}{l}\text { The REG Proced } \\
\text { Mode1: MODEL } \\
\text { ndent Variable: }\end{array}$ & & & \\
\hline & & $\begin{array}{l}\text { Numb } \\
\text { Numb }\end{array}$ & $\begin{array}{l}\text { ber of } \\
\text { ber of }\end{array}$ & $\begin{array}{l}\text { observations Re } \\
\text { observations US }\end{array}$ & $\begin{array}{l}69 \\
69\end{array}$ & & \\
\hline & & & & Analysis of var & ance & & \\
\hline Source & & & DF & $\begin{array}{r}\text { Sum of } \\
\text { squares }\end{array}$ & $\begin{array}{r}\text { Mean } \\
\text { Square }\end{array}$ & F value & $\mathrm{Pr}>\mathrm{F}$ \\
\hline $\begin{array}{l}\text { Mode1 } \\
\text { Error } \\
\text { Corrected }\end{array}$ & & & $\begin{array}{l}1 \\
67 \\
68\end{array}$ & $\begin{array}{l}0.01079 \\
0.00870 \\
0.01949\end{array}$ & $\begin{array}{r}0.01079 \\
0.00012980\end{array}$ & 83.12 & $<.0001$ \\
\hline & $\begin{array}{l}\text { Root } \\
\text { Depen } \\
\text { Coeff }\end{array}$ & $\begin{array}{l}\text { MSE } \\
\text { ident } \\
f \text { Var }\end{array}$ & Mean & $\begin{array}{r}0.01139 \\
0.02348 \\
48.52808\end{array}$ & $\begin{array}{l}\text { R-Square } \\
\text { Adj R-Sq }\end{array}$ & $\begin{array}{l}0.5537 \\
0.5470\end{array}$ & \\
\hline & & & & Parameter Estim & tes & & \\
\hline Variable & Labe1 & & DF & $\begin{array}{l}\text { Parameter } \\
\text { Estimate }\end{array}$ & $\begin{array}{r}\text { Standard } \\
\text { Error }\end{array}$ & $\mathrm{t}$ value & $\operatorname{Pr}>|t|$ \\
\hline $\begin{array}{l}\text { Intercept } \\
\text { AVGCD }\end{array}$ & $\begin{array}{l}\text { Interce } \\
\text { AVGCD }\end{array}$ & & $\begin{array}{l}1 \\
1\end{array}$ & $\begin{array}{r}-0.01372 \\
0.00212\end{array}$ & $\begin{array}{r}0.00430 \\
0.00023230\end{array}$ & $\begin{array}{r}-3.19 \\
9.12\end{array}$ & $\begin{array}{l}0.0022 \\
<.0001\end{array}$ \\
\hline
\end{tabular}


Average DBH

The SAS System

The REG Procedure

Mode 1: MODEL1

Dependent Variable: BAGY

$\begin{array}{ll}\text { Number of Observations Read } & 69 \\ \text { Number of Observations Used } & 69\end{array}$

Analysis of Variance

$\begin{array}{lrrrrr}\text { Source } & \text { DF } & \begin{array}{r}\text { Sum of } \\ \text { Squares }\end{array} & \begin{array}{r}\text { Mean } \\ \text { Square }\end{array} & \text { F value } & \text { Pr }>\text { F } \\ \text { Mode1 } & 1 & 0.01464 & 0.01464 & 202.58 & <.0001 \\ \text { Error } & 67 & 0.00484 & 0.00007228 & & \\ \text { Corrected Total } & 68 & 0.01949 & & \\ & & & & \\ & & & & \\ & \begin{array}{l}\text { Root MSE } \\ \text { Dependent Mean } \\ \text { Coeff Var }\end{array} & 0.00850 & \text { R-Square } & 0.7515 \\ & 36.21407 & \text { Adj R-Sq } & 0.7478\end{array}$

Parameter Estimates

\begin{tabular}{|c|c|c|c|c|c|c|}
\hline Variable & Labe1 & DF & $\begin{array}{l}\text { Parameter } \\
\text { Estimate }\end{array}$ & $\begin{array}{r}\text { Standard } \\
\text { Error }\end{array}$ & t value & $\operatorname{Pr}>|t|$ \\
\hline $\begin{array}{l}\text { Intercept } \\
\text { AVGDBH }\end{array}$ & $\begin{array}{l}\text { Intercept } \\
\text { AVGDBH }\end{array}$ & $\begin{array}{l}1 \\
1\end{array}$ & $\begin{array}{r}-0.02608 \\
0.00569\end{array}$ & $\begin{array}{r}0.00363 \\
0.00039944\end{array}$ & $\begin{array}{l}-7.19 \\
14.23\end{array}$ & $\begin{array}{l}<.0001 \\
<.0001\end{array}$ \\
\hline
\end{tabular}


Average Total Height Power Regression $B A G Y=b 0 * A V G T H \wedge b 1$ The SAS System

The NLIN Procedure Dependent Variable BAGY Method: Gauss-Newton

Iterative Phase

$\begin{array}{rrrr}\text { Iter } & \text { b0 } & \text { b1 } & \begin{array}{r}\text { Sum of } \\ \text { Squares }\end{array} \\ 0 & 9 \mathrm{E}-8 & 2.8797 & 0.0181 \\ 1 & 4.683 \mathrm{E}-8 & 3.0657 & 0.0163 \\ 2 & 5.538 \mathrm{E}-8 & 3.0559 & 0.0156 \\ 3 & 5.586 \mathrm{E}-8 & 3.0553 & 0.0156 \\ 4 & 5.589 \mathrm{E}-8 & 3.0551 & 0.0156\end{array}$

NOTE: Convergence criterion met.

Estimation Summary

$\begin{array}{lr}\text { Method } & \text { Gauss-Newton } \\ \text { Iterations } & 4 \\ \text { R } & 3.491 \mathrm{E}-6 \\ \text { PPC(b1) } & 7.514 \mathrm{E}-6 \\ \text { RPC(b1) } & 0.000039 \\ \text { Object } & 1.481 \mathrm{E}-9 \\ \text { Objective } & 0.015624 \\ \text { Observations Read } & 69 \\ \text { Observations Used } & 69 \\ \text { Observations Missing } & 0\end{array}$

NOTE: An intercept was not specified for this model.

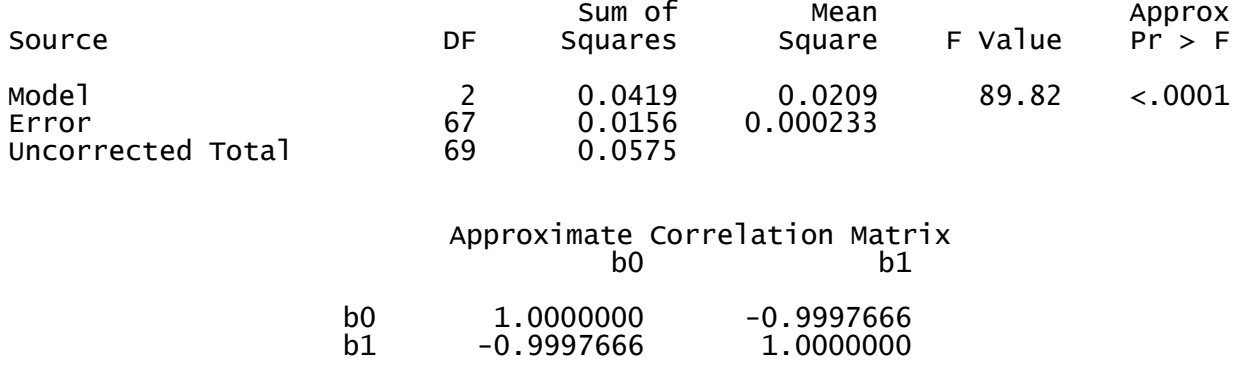


Average Total Height without beta 0 BAGY $=A V G T H \wedge b 1$

The SAS System

The NLIN Procedure

\begin{tabular}{|c|c|c|c|c|c|c|}
\hline & Source & DF & $\begin{array}{l}\text { Sum of } \\
\text { Squares }\end{array}$ & $\begin{array}{r}\text { Mean } \\
\text { Square }\end{array}$ & value & $\begin{array}{l}\text { Approx } \\
\mathrm{Pr}>\mathrm{F}\end{array}$ \\
\hline & $\begin{array}{l}\text { Mode1 } \\
\text { Error } \\
\text { Uncorrected Total }\end{array}$ & $\begin{array}{l}1 \\
68 \\
69\end{array}$ & $\begin{array}{l}0.0345 \\
0.0231 \\
0.0575\end{array}$ & $\begin{array}{r}0.0345 \\
0.000339\end{array}$ & 101.67 & $<.0001$ \\
\hline \multirow{4}{*}{ Limits } & Parameter & Estimate & $\begin{array}{r}\text { Approx } \\
\text { Std Error }\end{array}$ & \multicolumn{2}{|c|}{ Approximate $95 \%$} & nfidence \\
\hline & \multirow[t]{3}{*}{ b1 } & -0.9032 & 0.0234 & -0.9499 & \multicolumn{2}{|c|}{-0.8565} \\
\hline & & \multicolumn{3}{|c|}{$\begin{array}{l}\text { Approximate } \\
\text { Correlation Matrix } \\
\text { b1 }\end{array}$} & & \\
\hline & & b1 & 1.0000 & 000 & & \\
\hline
\end{tabular}


Tree Characteristics Multiple Linear Regression The SAS System

The REG Procedure

Mode 1: MODEL1

Dependent Variable: BAGY

$\begin{array}{ll}\text { Number of Observations Read } & 69 \\ \text { Number of Observations Used } & 69\end{array}$

Analysis of Variance

\begin{tabular}{|c|c|c|c|c|c|}
\hline Source & DF & $\begin{array}{r}\text { Sum of } \\
\text { Squares }\end{array}$ & $\begin{array}{r}\text { Mean } \\
\text { Square }\end{array}$ & F value & $\mathrm{Pr}>\mathrm{F}$ \\
\hline $\begin{array}{l}\text { Mode1 } \\
\text { Error } \\
\text { Corrected Total }\end{array}$ & $\begin{array}{r}4 \\
64 \\
68\end{array}$ & $\begin{array}{l}0.01569 \\
0.00379 \\
0.01949\end{array}$ & $\begin{array}{r}0.00392 \\
0.00005928\end{array}$ & 66.18 & $<.0001$ \\
\hline & Mean & $\begin{array}{r}0.00770 \\
0.02348 \\
32.79536\end{array}$ & $\begin{array}{l}\text { R-Square } \\
\text { Adj R-Sq }\end{array}$ & $\begin{array}{l}0.8053 \\
0.7931\end{array}$ & \\
\hline
\end{tabular}

Parameter Estimates

$\begin{array}{llrrrrr}\text { Variable } & \text { Label } & \text { DF } & \begin{array}{r}\text { Parameter } \\ \text { Estimate }\end{array} & \begin{array}{r}\text { Standard } \\ \text { Error }\end{array} & t \text { Value } & \operatorname{Pr}>|t| \\ \text { Intercept } & \text { Intercept } & 1 & -0.05627 & 0.00902 & -6.24 & <.0001 \\ \text { AVGDBH } & \text { AVGDBH } & 1 & 0.00333 & 0.00068595 & 4.85 & <.0001 \\ \text { AVGCD } & \text { AVGCD } & 1 & 0.00080777 & 0.00026379 & 3.06 & 0.0032 \\ \text { AVGA } & \text { AVGA } & 1 & 0.00040865 & 0.00018142 & 2.25 & 0.0277 \\ \text { AVGTH } & \text { AVGTH } & 1 & 0.00033452 & 0.00012498 & 2.68 & 0.0094\end{array}$

